\title{
Large Precipitate Hydrolysis Aqueous (PHA) Heel Process Development for the Defense Waste Processing Facility (DWPF)
}

by

D. P. Lambert

Westinghouse Savannah River Company

Savannah River Site

Aiken, South Carolina 29808

C. S. Boley

R. A. Jacobs

DOE Contract No. DE-AC09-96SR18500

This paper was prepared in connection with work done under the above contract number with the U. S.

Department of Energy. By acceptance of this paper, the publisher and/or recipient acknowledges the U.S. Government's right to retain a nonexclusive, royalty-free license in and to any copyright covering this paper, along with the right to reproduce and to authorize others to reproduce all or part of the copyrighted paper.

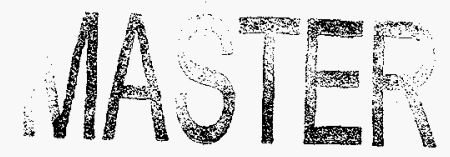

DISTRDUTON OF TMIS DOCUMENT IS UNLMITED

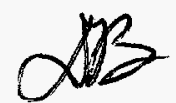




\section{DISTRIBUTION:}

L. M. Papouchado, 773-A

E. W. Holtzscheiter, 773-A

C.R. Goetzman, 773-A

C. T. Randall, 704-T

L.F. Landon, 704-1T

D. A. Crowley, 773-43A

J. R. Harbour, 773-43A

T. B. Edwards, 773-42A

R. A. Jacobs, 704-T

R. E. Eibling, 704-T

K. G. Brown, 704-1T

A. S. Choi, 704-1T

D. P. Lambert, 704-1T

C. S. Boley, 703-H

M. F. Williams, 704-1T

T. L. Fellinger, 773-A

N. E. Bibler, 773-A

M. N. Brosee, 704-S

J. F. Ortaldo, 704-S

W. D. Kerley, 704-S

S. L. Marra, 704-25S

R. E. Edwards, Jr. 704-25S

H. H. Elder, 704-S

M. R. Norton, 704-27S

J. E. Occhipinti, 704-27S

D.F. Gehr, 704-35S

J. P. Schwenker, 704-35S

S. G. Phillips, 704-27S

P. H. Werling

STI, 703-43A (4) 
Westinghouse

Savannah River Company

Alken, SC 29808

WSRC-TR-97-00390-TL, Revision 0

Keywords: DWPF, SPC, PHA Heel

Retention: Permanent

May 12, 1997

M. N. BROSEE, MANAGER

DEFENSE WASTE PROCESSING FACILITY

\section{Large Precipitate Hydrolysis Aqueous (PHA) Heel Process for the Defense Waste Processing Facility (DWPF) (U)}

In response to the Technical task Request \# HLW/DWPF/TTR-970134, a series of laboratory scale process simulations were performed to investigate an alternative flowsheet for Salt Processing Cell (SPC) precipitate processing. The new flowsheet would increase the solids concentration of the SPC aqueous product and decrease the condensate generation during DWPF processing.

This document details the technical bases for a flowsheet that uses product from the previous precipitate reactor (PR) batch as the source of the PR heel for the subsequent batch instead of creating heel of water, formic acid and copper. This maximizes the concentration of the SPC aqueous product and minimizes the copper added to the aqueous product.

It is important for DWPF to incorporate the phenylboronic acid reaction rates into their safety analyses since the reaction rates measured during this experiments are higher than those used during some accident analysis calculations. The higher reaction rates do not affect normal processing, only the accident scenarios in the DWPF Safety Analysis Report.

If you have additional questions regarding the attached report, please contact D. P. Lambert (7-7680).

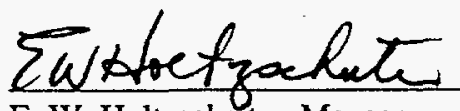

E. W. Holtzscheiter, Manager

SRTC-Immobilization Technology Section 


\section{LARGE PRECIPITATE HYDROLYSIS AQUEOUS (PHA) HEEL PROCESS DEVELOPMENT FOR THE DEFENSE WASTE PROCESSING FACILITY (DWPF) (U)}

D. P. Lambert

C. S. Boley

R. A. Jacobs

Westinghouse Savannah River Company

Savannah River Site Aiken, SC 29808

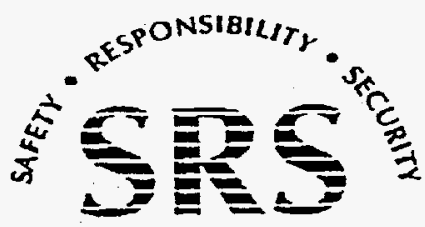




\section{DISCLAIMER}

This report was prepared as an account of work sponsored by an agency of the United States Government. Neither the United States Government nor any agency thereof, nor any of their employees, makes any warranty, express or implied, or assumes any legal liability or responsibility for the accuracy, completeness, or usefulness of any information, apparatus, product, or process disclosed, or represents that its use would not infringe privately owned rights. Reference herein to any specific commercial product, process, or service by trade name, trademark, manufacturer, or otherwise does not necessarily constitute or imply its endorsement, recommendation, or favoring by the United States Government or any agency thereof. The views and opinions of authors expressed herein do not necessarily state or reflect those of the United States Government or any agency thereof.

This report has been reproduced directly from the best available copy.

Available to DOE and DOE contractors from the Office of Scientific and Technical Information, P.O. Box 62, Oak Ridge, TN 37831; prices available from (615) 576-8401.

Available to the public from the National Technical Information Service, U.S. Department of Commerce, 5285 Port Royal Road, Springfield, VA 22161. 


\section{DISCLAIMER}

Portions of this document may be illegible electronic image products. Images are produced from the best available original document. 
Distribution Category: To Be Determined

Keywords: DWPF, SPC, PHA Heel

Retention: Permanent

\section{LARGE PRECIPITATE HYDROLYSIS AQUEOUS (PHA) HEEL PROCESS DEVELOPMENT FOR THE DEFENSE WASTE PROCESSING FACILITY (DWPF) (U)}

D. P. Lambert

C. S. Boley

R. A. Jacobs

Publication Date: May 12, 1998 


\section{Approvals}

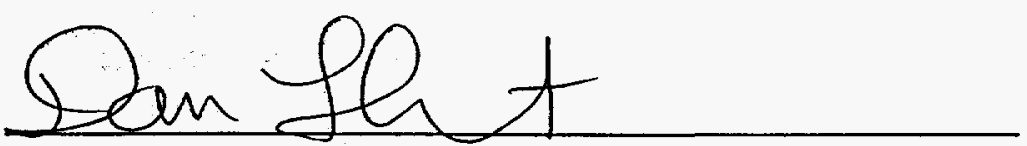

D. P. Lambert, Author
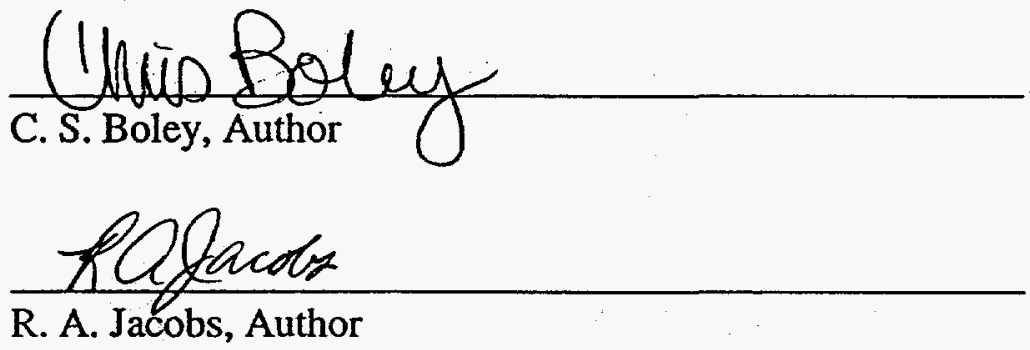

R. E. Eibling, Technical Reviewer

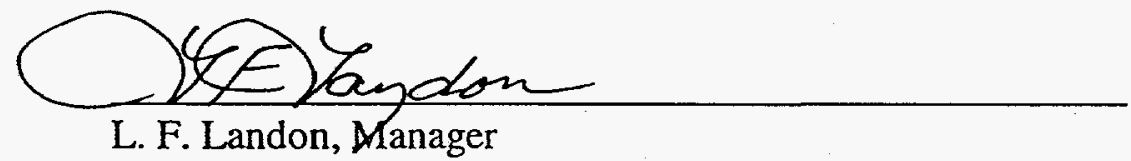

EWtactrohate

E. W. Holtzscheiter, Immobilization Technology

Westinghouse Savannah River Company

Savannah River Site

Aiken, SC 29808

\section{Puasell \& Ebling}

$$
\frac{5-13-98}{\text { Date }}
$$
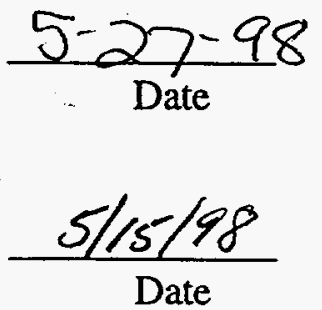

$\frac{5-20-1998}{\text { Date }}$

$\frac{5 / 21 / 98}{\text { Date }}$
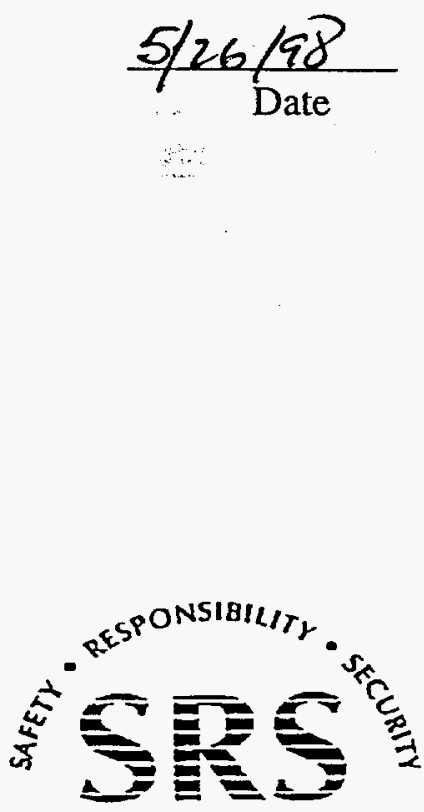

SAVANNAH RIVER SITE

PREPARED FOR THE U.S. DEPARTMENT OF ENERGY UNDER CONTRACT NO. DE-AC09-96SR18500 


\section{EXECUTIVE SUMMARY}

A modification to the Precipitate Hydrolysis flowsheet used in DWPF Waste Qualification Runs has been developed. Rather than transferring essentially all the aqueous product (PHA) to the Precipitate Reactor Bottoms Tank (PRBT) at the conclusion of each Precipitate Reactor (PR) cycle (necessitating the addition of large amounts of water to the PR to ensure the steam coils are covered before commencing the next PR cycle), this proposed flowsheet leaves behind sufficient PHA (about one-third that of that produced in a PR cycle) to assure the steam coils are covered. This Large PHA heel flowsheet (which leaves 1,500 gallons of PHA behind as opposed to the $\underline{\text { Small }}$ PHA heel of $\sim 25$ gallons left during Waste Qualification runs) eliminates the need for water addition and consequently produces an aqueous product significantly higher in solids concentration. The advantages of this process are:

- Reduces the PHA batch size to be blended with a sludge batch

- Reduces SRAT cycle time by 11-13 hours

- Reduces volume of condensate produced in each SRAT cycle

- Reduces the potential for increasingly greater hydrogen production rates attributed to solids accumulation in the PR due to the PHA not being agitated during the end of each PHA transfer from the PR to the PRBT (i.e. PHA level drops below the PR agitator)

- Reduces the copper content in the glass

Based on the testing described in this document, it is recommended that the copper level in the PR be changed to $475 \mathrm{ppm}$ and that a PHA heel of 1,500 gallons be left behind in the PR after each batch. This heel will result in a new PHA steady state concentration of $5.53 \mathrm{wt} \%$ total solids as opposed to the old level of $4.0 \mathrm{wt} \%$. This increase in solids loading will allow the PRBT to hold enough PHA for a single SRAT batch (less total PHA will have to be fed since it is at a higher concentration). This will represent a time savings to DWPF of approximately 11-13 hours of SRAT processing. The lower copper level will result in a raw materials cost savings to DWPF, since only half of the original amount of cupric nitrate will be used in the process ( $475 \mathrm{ppm}$ copper opposed to 950 $\mathrm{ppm}$ ) and will essentially eliminate copper being the PHA batching constraint.

During this testing, the total amount of organic in the PHA product was found to be $1 \%$ lower in the large PHA heel process. At the $5 \%$ confidence level, only three streams were found to have a statistically significant amount of organic in the product PHA. The mean differences for these three data streams were $0.749 \mathrm{lbs}, 2.743 \mathrm{lbs}$ and $-0.293 \mathrm{lbs}$, respectively. Such slight differences will not have practical significance for DWPF processing. The least significant differences for these results also indicate that the sensitivity of the statistical methods used were sufficient to recognize differences of practical concern. No new high boiling organic compounds were observed in the large PHA heel process product.

During the initial series of large PHA heel hydrolysis process simulations, the peak hydrogen rate increased with each subsequent run (a 1.5 fold increase over the six runs) See Table 1. This same behavior was observed during a series of water heel hydrolysis 
Westinghouse Savannah River Company

Savannah River Technology Center

WSRC-TR-97-00390

Revision 0

process simulations (see Table 1). To test the theory that PHA solids may have been accumulating in the reactor during pump out at the conclusion of each run (where the PHA level fell below the agitator during the pump out), an additional series of hydrolysis simulation runs were conducted where the PHA level in the reactor was not permitted to fall below the agitator. In this series of experiments the maximum hydrogen generation rate observed actually occurred in the second run. Over the seven runs the peak hydrogen rate averaged $0.026+1-0.004 \mathrm{lb} / \mathrm{hr}$ (based on a 6,000 gallon DWPF PHA batch). These rates were comparable to those seen in similar experiments performed with precipitate from the same batch ${ }^{1}$.

Table 1 - Maximum Hydrogen Flow Comparison, lb/hr/6,000 gal DWPF PHA batch

\begin{tabular}{|l|c|c|}
\hline Run Description & Run 1 & Run 6 \\
\hline Small PHA Heel & 0.020 & 0.030 \\
\hline Large PHA Heel & 0.029 & 0.039 \\
\hline
\end{tabular}

The important conclusion from these additional tests is that the ability to agitate the contents of the PR during the transfer to the PRBT is crucial to maintaining a safe level of hydrogen production in the Salt Cell in DWPF. If the liquid level in the tank drops below 1,200 gallons during the transfer, agitation is lost and the sludge solids will settle and cause an increase in hydrogen production for subsequent batches in the SPC. Therefore it is recommended that the PR level not drop below 1,300 gallons, so that the vessel will be adequately agitated at all times. 


\section{TABLE OF CONTENTS}

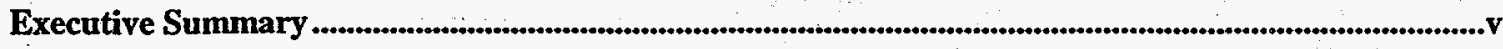

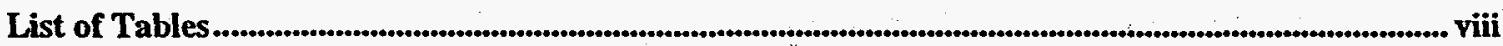

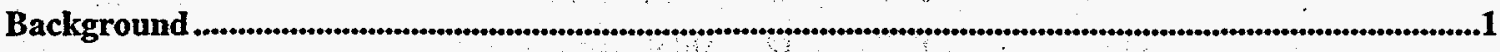

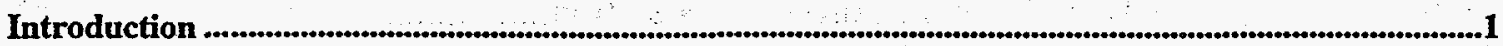

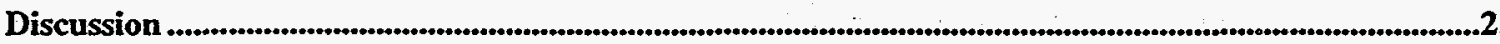

Experimentation

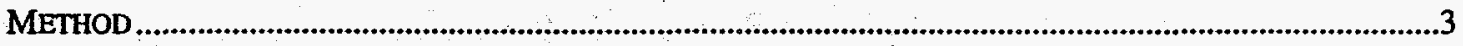

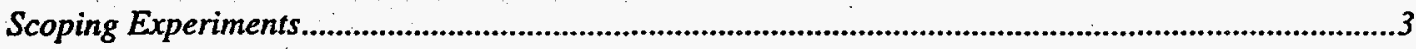

Process Demonstration Experiments ..............................................................................................................

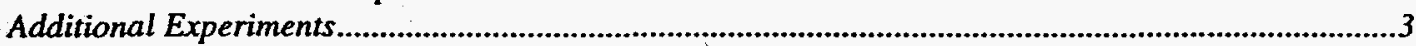

PRECIPTATE FEED COMPOSTION .....................................................................................................................

SCALING

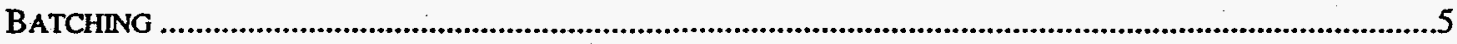

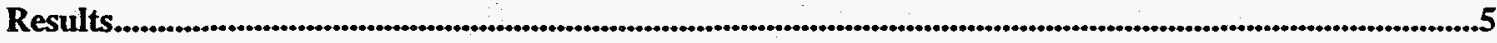

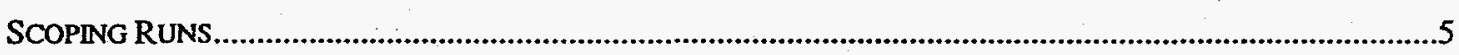

PROCESS DEMONSTRATION EXPERIMENTS

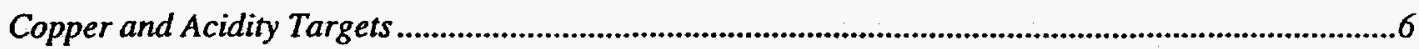

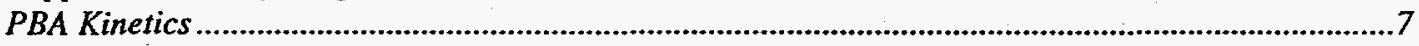

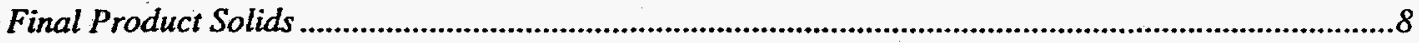

Decanter Efficiency and Organic Distribution .....................................................................................

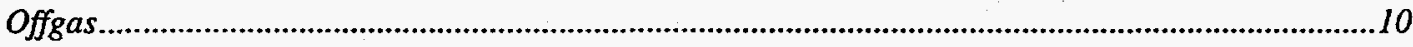

Explanation of Increasing Hydrogen ..................................................................................................13

Impact on organic evaporator cycle.......................................................................................................19

Recommendations for Additional Studies ...........................................................................................19

Limitations of Small Scale Testing with Simulants......................................................................................20

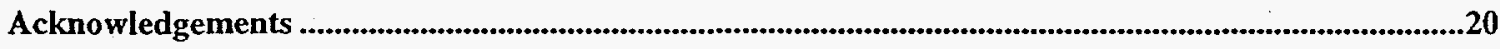

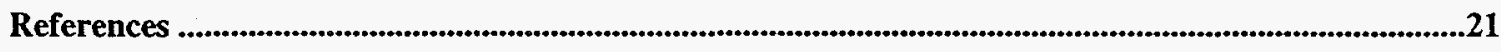

Appendix A - laboratory setup and procedures..................................................................................

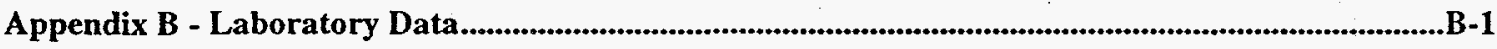

Appendix C - Batch calculations ........................................................................................................... 
Westinghouse Savannah River Company

Savannah River Technology Center

WSRC-TR-97-00390

Revision 0

\section{LIST OF FIGURES}

Figure 1- PBA Destruction During Scoping Runs .............................................................. 5

Figure 2 - PBA Destruction During the Five-hour Hold ....................................................... 7

Figure 3 - Organic Content of Decanter Organic .................................................................. 9

Figure 4 - Organic Content in Aqueous Products ............................................................... 9

Figure $5-\mathrm{CO}_{2}$ Generation During Process Demonstration Runs ....................................... 11

Figure 6 - Small PHA Heel Process Hydrogen Generation.................................................. 12

Figure 7 - Large PHA Heel Process Hydrogen Generation................................................ 13

Figure 8 - Hydrogen Generation in Further Studies ............................................................ 14

Figure 9 - Hydrogen Generation During Tests 1-7 .......................................................... 16

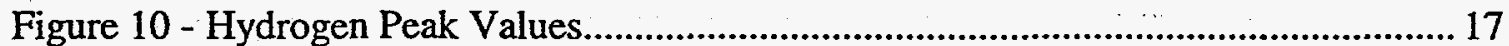

Figure 11 - Formic Acid/Copper Solution Boiled in Kettle ........................................... 18

\section{LIST OF TABLES}

Table 1 - Maximum Hydrogen Flow Comparison, lb/hr/6,000 gal DWPF PHA batch ..... vi

Table 2 - Precipitate Feed Composition …………………................................................. 4

Table 3 - Noble Metal Levels in Added Sludge, dry basis.................................................. 4

Table 4 -Scaling for Large PHA Heel Experiments ............................................................ 4

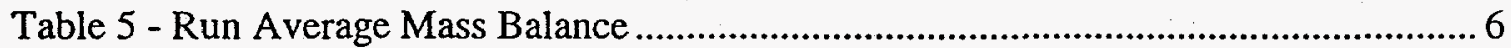

Table 6 - PHA Final Acidity and Soluble Copper Level..................................................... 6

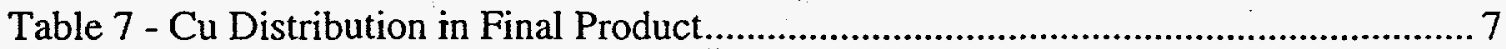

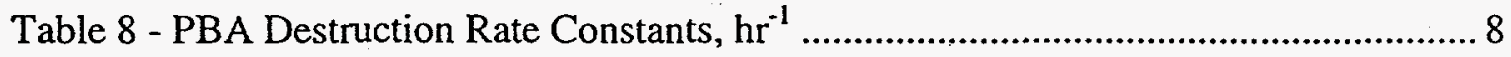

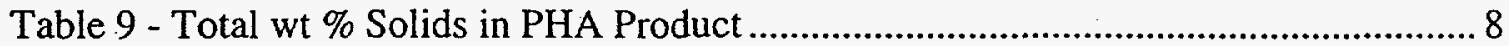

Table 10 - Hydrogen Peak Comparison ..................................................................... 15

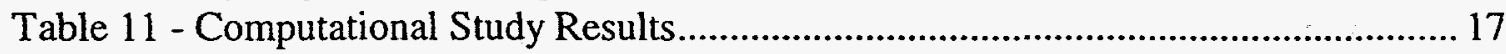




\section{BACKGROUND}

In 1985, a recommendation was made to never heat the PR with its steam coils uncovered for fear of thermal decomposition of tetraphenylborate (TPB) occurring and the potential for formation of organic high boilers. Therefore, the original Salt Cell Process left some PHA behind in the PR to cover the coils. When the hydroxylamine nitrate (HAN) process ${ }^{2}$ was implemented to mitigate the impact of high nitrite in the precipitate feed $(0.2 \mathrm{M})$ on organic high boiler production, an accumulation of high boiling organic compounds was observed in the PHA from run to run. The process was therefore changed so that all the PHA product was pumped out of the PR. However, this required an addition of 1,400-1,500 gallons of water to cover the coils before the start of the next run. In 1992, the Late Wash process replaced the HAN process ${ }^{3}$. This new process limited the concentration of nitrite in the precipitate feed to a maximum of $0.01 \mathrm{M}$ and consequently reduced the concentration of high boiling organic compounds in the PHA. Pumping out the PR completely became unnecessary. However, it remained part of the process throughout Waste Qualification Runs.

In 1993, a task team met to discuss methods to reduce the amount of condensate recycled in DWPF. A report was issued recommending, among other things, a return to the original strategy (leaving a large PHA heel behind in the PR) ${ }^{4}$. DWPF subsequently requested development work to allow a heel to be left behind ${ }^{5}$.

Included in this request was the determination of the minimal copper level (in a range from 475 to $950 \mathrm{ppm}$ ) needed for hydrolysis, in response to an SRTC recommendation to lower the copper limit in the melter feed ${ }^{6}$. The copper limit was imposed to minimize copper deposition in the melter, thereby lengthening melter life.

\section{INTRODUCTION}

To leave a large PHA heel behind in the PR, it was necessary to demonstrate that the concentration of high boiling organic compounds was not increasing in the PHA with each successive batch, and that the peak hydrogen production in the in the SPC would be within the current DWPF safety limits ${ }^{7.8 .9}$. To reduce the copper level in the PHA, it was necessary to confirm that the phenylboronic acid (PBA) could be destroyed at a lower copper concentration during the 5-hour hold time at $90^{\circ} \mathrm{C}$. The Phase I scoping studies were designed to determine the minimum level of copper that would meet this objective. The Phase II studies were designed as a process demonstration for both a large PHA heel and a small PHA heel flowsheet, so that the organic accumulation and offgas production in each could be compared. Specific objectives of these tasks were:

Phase I - Scoping Experiments

Develop the appropriate process operating parameters for the Phase II demonstrations. 
1. Complete a series of experiments with a large PHA Heel process and compare with a series of experiments with a small PHA heel (current flowsheet). A minimum of 6 sequential experiments with each flowsheet was selected to attain $99.9 \%$ of steady state PHA solids concentration. Tests to be conducted in stainless steel equipment (to be more prototypic of DWPF).

2. Use late-washed, irradiated (approximately $200 \mathrm{Mrad}$ ) SPC precipitate feed, prepared from non-radioactive simulants, to be as prototypic of DWPF radioactive precipitate feed as possible.

3. Complete a statistical study of the PHA product to determine if there is a difference in the organic concentration and distribution.

4. Determine the TPB/phenylboric acid (PBA) hydrolysis reaction kinetics for each test. Determine if there is a difference in reaction rates between the two flowsheets.

5. Determine the composition of the organic product and measure the decanter extraction efficiency. Determine if there is a difference in organic product composition.

6. Measure the $\mathrm{H}_{2}$ and $\mathrm{N}_{2} \mathrm{O}$ generation rates during each test.

7. Measure the copper distribution in the $\mathrm{PHA}\left(\mathrm{Cu}^{0}, \mathrm{Cu}^{+1}, \mathrm{Cu}^{+2}\right)$.

If the PHA heel product contains a significantly higher quantity of high boiling organic compounds, run a SRAT cycle and a Slurry Mix Evaporator (SME) cycle to determine the effects of this PHA on Chemical Processing Cell (CPC) processing. The revised flowsheet must meet all current DWPF requirements including a hydrogen generation rate below the existing hydrogen evolution design basis for the SRAT $(0.65 \mathrm{lb} / \mathrm{hr}$ for a 6,000 gallon batch) and the SME $(0.23 \%$ hr for a 6,000 gallon batch).

\section{DISCUSSION}

The current hydrolysis process requires pumping virtually all of the PHA product into the Precipitate Reactor Bottoms Tank (PRBT) after conclusion of the PR cycle, leaving behind a small PHA heel of $\sim 25$ gallons. It also requires the addition of approximately 1500 gallons of water to the PR before every batch to bring the level up to cover the steam coils. In the large PHA Heel Flowsheet, 1500 gallons of PHA is instead left behind in the PR to cover the coils.

There are several benefits to the large PHA Heel process. Leaving a PHA heel behind will ultimately create an aqueous product higher in wt \% solids. This will not only reduce the feed time and shorten the CPC processing time, but will also reduce overall DWPF condensate production. With the new restraint on the amount of copper in the glass $(0.35$ wt $\%$ vs. 0.50 wt $\%)^{10}$, this flowsheet testing was also designed to determine the minimal amount of copper needed to destroy the PBA within the range of $475 \mathrm{ppm}$ to $950 \mathrm{ppm}$. A reduction in the copper level in the PHA will reduce raw materials cost since a simulated heel will not have to be added before each batch. In addition, lower copper levels in the melter could lengthen the melter life expectancy. 


\section{Precipitate Feed Composition}

A single container of late-washed KTPB simulant, irradiated to $200 \mathrm{Mrad}$ and containing $\sim 10.2$ wt \% total solids was the source of feed used in all experiments. The precipitate

Table 2 - Precipitate Feed Composition

\begin{tabular}{|r|r|}
\hline Component & Concentration \\
\hline Nitrite & $410 \mathrm{mg} / \mathrm{L}$ \\
\hline $\mathrm{Cs}$ & $345 \mathrm{ppm}$ \\
\hline Purex Sludge & $6000 \mathrm{ppm}$ \\
\hline $\mathrm{Hg}$ & $2340 \mathrm{ppm}$ \\
\hline $\mathrm{TPB}-$ & $0.25 \mathrm{M}$ \\
\hline
\end{tabular}

to simulate a worst case $\mathrm{H}_{2}$ production. Table 3 shows the noble metals concentration in the sludge added to the precipitate at $6000 \mathrm{ppm}$. The HM levels (DWPF design basis) are given for comparison. feed was from batch PF-143. Key component levels are shown in Table 2. This precipitate was chosen as a worst case scenario for the production of high boiling organic compounds. The 40-L carboy containing the irradiated KTPB slurry was spiked with $6000 \mathrm{ppm}$ sludge solids with conservative levels of noble metals

\section{Table 3 - Noble Metal Levels in Added} Sludge, dry basis

\begin{tabular}{|c|c|c|}
\hline Noble Metal & \multicolumn{1}{|c|}{$\begin{array}{c}\text { Testing } \\
\text { (wt\%) }\end{array}$} & $\begin{array}{c}\text { HM levels } \\
\text { (wt\%) }\end{array}$ \\
\hline Ruthenium & $0.216 \%$ & $0.217 \%$ \\
\hline Rhodium & $0.044 \%$ & $0.038 \%$ \\
\hline Palladium & $0.095 \%$ & $0.079 \%$ \\
\hline
\end{tabular}

\section{Scaling}

The experiments were designed to be as prototypic of DWPF future processing as possible in $1 / 7,570$ and $1 / 30,280$ scale laboratory facilities. The feed flow rate, boilup rate, and purge rates were all scaled from actual DWPF rates. The scaling for both Phase I \& II runs is summarized in Table 4.

Table 4 -Scaling for Large PHA Heel Experiments

\begin{tabular}{|c|c|c|c|}
\hline & DWPF & Phase I & Phase II \\
\hline TPB, total wt\% & $8.45 \%$ & $8.45 \%$ & $8.45 \%$ \\
\hline Precipitate : Heel Volume Ratio & 3.33 & 3.33 & 3.33 \\
\hline Heel Volume & $1,500 \mathrm{gal}$ & $188 \mathrm{ml}$ & $750 \mathrm{ml}$ \\
\hline Precipitate Volume & 5,000 gal & $625 \mathrm{ml}$ & $2,500 \mathrm{ml}$ \\
\hline Sampling PRFT Prime Water & $45 \mathrm{gal}$ & $5.6 \mathrm{ml}$ & $22.5 \mathrm{ml}$ \\
\hline Transfer PRFT Prime Water & $45 \mathrm{gal}$ & $5.6 \mathrm{ml}$ & $22.5 \mathrm{ml}$ \\
\hline Precipitate feedrate & $30.0 \mathrm{gpm}$ & $3.8 \mathrm{ml} / \mathrm{min}$ & $15.0 \mathrm{ml} / \mathrm{min}$ \\
\hline Batch size & $6,348 \mathrm{gal}$ & $793 \mathrm{ml}$ & $3,174 \mathrm{ml}$ \\
\hline Sampling PR Heel Prime Water & 45 gal & $5.6 \mathrm{ml}$ & $22.5 \mathrm{ml}$ \\
\hline Sampling PHA Prime Water & $90 \mathrm{gal}$ & $11.3 \mathrm{ml}$ & $45.0 \mathrm{ml}$ \\
\hline Transfer PHA Prime Water & 45 gal & $5.6 \mathrm{ml}$ & $22.5 \mathrm{ml}$ \\
\hline $\mathrm{CO} 2$ purge rate & $4.7 \mathrm{scfm}$ & $4.00 \mathrm{scc} / \mathrm{min}$ & $15.82 \mathrm{scc} / \mathrm{min}$ \\
\hline Argon purge rate & $\ldots$ & $0.40 \mathrm{scc} / \mathrm{min}$ & $1.76 \mathrm{scc} / \mathrm{min}$ \\
\hline Total purge rate & $4.7 \mathrm{scfm}$ & $4.40 \mathrm{scc} / \mathrm{min}$ & $17.58 \mathrm{scc} / \mathrm{min}$ \\
\hline Steam flow & $2,000 \mathrm{lb} / \mathrm{hr}$ & $0.50 \mathrm{~g} / \mathrm{min}$ & $2.00 \mathrm{~g} / \mathrm{min}$ \\
\hline Condenser exit temp, ${ }^{\circ} \mathrm{C}$ & $40-45$ & $40-45$ & $40-45$ \\
\hline SCVC exit temp, ${ }^{\circ} \mathrm{C}$ & 12 & 12 & 12 \\
\hline Copper nitrate solution, wt\% $\mathrm{Cu}$ & $1.5 \%$ & $1.5 \%$ & $1.5 \%$ \\
\hline Formic acid, wt $\%$ & $90 \%$ & $90 \%$ & $90 \%$ \\
\hline
\end{tabular}




\section{Batching}

In each of the runs, the feed to heel volumetric ratio was 3.33 , scaled down from a 4,500 gallon precipitate batch in DWPF. For the water heel runs and the first large PHA heel run, the $-750 \mathrm{ml}$ of heel solution consisted of a $0.25 \mathrm{M}$ formic, $475 \mathrm{ppm}$ copper solution. In runs 2-6 of the large PHA heel experiments, the $750 \mathrm{ml}$ heel consisted of PHA from the previous run. A $1.47 \mathrm{wt} \%$ copper solution and $90 \mathrm{wt} \%$ formic acid were added to the heel to target a final product containing 475 ppm copper and a formic acid molarity of 0.25 . Acid requirements were calculated based on the results of five analyses, including TPB content, an acid titration to $\mathrm{pH} 5.5$, total solids, specific gravity, and nitrite content. Appendix $\mathrm{C}$ contains these calculations.

\section{RESULTS}

\section{Scoping Runs}

Scoping runs were performed at differing acid and copper levels to determine the minimum copper required (within a range of 475 to $950 \mathrm{ppm}$ ) to destroy the phenylboronic acid (PBA). These experiments consisted only of a feed cycle and a 5hour hold at $90^{\circ} \mathrm{C}$. Samples were pulled every hour during the 5-hour hold and analyzed for PBA concentration. Two experiments were run at $475 \mathrm{ppm}$ copper, one with a final acid target of $0.19 \mathrm{M}$ and the second with a target of $0.31 \mathrm{M}$. The measured heel acid for the runs was $0.13 \mathrm{M}$ and $0.29 \mathrm{M}$, respectively. The lower amount was attributed to minor computational effects (i.e. analysis were low). These runs served to slightly adjust the algorithm used to calculate the acid additions in the larger scale runs.

Figure 1 shows the destruction of PBA over time during both of the runs. The $475 \mathrm{ppm}$ copper level was sufficient to destroy the PBA within a five-hour $90^{\circ} \mathrm{C}$ hold in both of

Figure 1- PBA Destruction During Scoping Runs

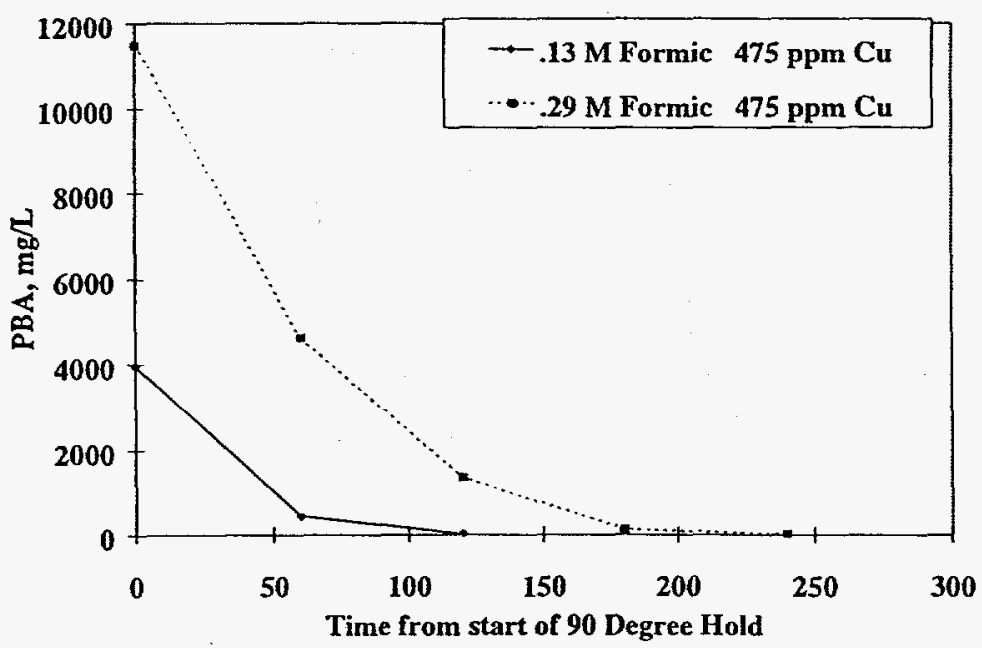
these experiments. The higher acid run destroyed the PBA at a slower rate than the lower acid run. Previous research shows that there is a parabolic relationship between acid level and PBA destruction rate $^{11}$. The higher level of acid fell on the downward slope of this curve. Because the lower copper level was successful at both acid levels, no other scoping runs were judged required, and this copper level became the basis for the study. 
Westinghouse Savannah River Company

WSRC-TR-97-00390

Savannah River Technology Center

Revision 0

\section{Process Demonstration Experiments}

A series of six sequential experiments were run for each of two processes (large and small PHA heel). The runs that simulated the current process are designated as "small PHA runs". The runs that simulated the alternative flowsheet are designated as "large PHA runs" and the run number is identified with the letter " $\mathrm{H}$ ". One set simulated the current DWPF Salt Cell process, using a formic acid/copper solution as the heel, and the other set simulated the proposed process, using PHA product as the heel. The entire hydrolysis process was simulated, including the 5-hour aqueous boil. Table 5 shows the average values of what was added and what was produced during the 12 experiments. The low standard deviation values imply high quality control of the experiments.

Table 5 - Run Average Mass Balance

\begin{tabular}{|l|l|l|}
\hline & \multicolumn{1}{|l|}{ Average } & Std. Dev. \\
\hline Precipitate Mass & $2502 \mathrm{~g}$ & 4 \\
\hline Water Mass & $113 \mathrm{~g}$ & 0.2 \\
\hline Heel Mass & $751 \mathrm{~g}$ & 0.04 \\
\hline Formic Acid Mass & $78 \mathrm{~g}$ & 6 \\
\hline Copper solution Mass & $83 \mathrm{~g}$ & 1 \\
\hline Decanter Aqueous Mass & $79 \mathrm{~g}$ & 3 \\
\hline Decanter Organic Mass & $67 \mathrm{~g}$ & 0.2 \\
\hline Total Mass at Start & $3673 \mathrm{~g}$ & 36 \\
\hline PHA Mass & $3197 \mathrm{~g}$ & 18 \\
\hline Samples Mass & $58 \mathrm{~g}$ & 6 \\
\hline Organic Mass & $273 \mathrm{~g}$ & 3 \\
\hline Aqueous Mass & $94 \mathrm{~g}$ & 6 \\
\hline Total, Mass at End & $3609 \mathrm{~g}$ & 44 \\
\hline Total Delta Mass & $-64 \mathrm{~g}$ & 13 \\
\hline Organic Mass Produced & $192 \mathrm{~g}$ & 3 \\
\hline
\end{tabular}

\section{Copper and Acidity Targets}

A $0.25 \mathrm{M}$ formic acid concentration in the PHA product was targeted in both processing scenarios. Table 6 lists the actual acidity of the final product in each of the six runs. The final acid fell short of the target in both of the initial runs. This was most likely due to an error in one of the analyses or the batching calculation not accounting for some other

Table 6 - PHA Final Acidity and Soluble Copper Level

\begin{tabular}{|c|c|c|c|c|}
\hline Run & \multicolumn{3}{|c|}{ Acidity, M } & Soluble Copper Level, ppm \\
\hline & $\begin{array}{c}\text { Small PHA } \\
\text { Heel }\end{array}$ & $\begin{array}{c}\text { Large PHA } \\
\text { Heel }\end{array}$ & $\begin{array}{c}\text { Small PHA } \\
\text { Heel }\end{array}$ & $\begin{array}{c}\text { Large PHA } \\
\text { Heel }\end{array}$ \\
\hline 1 & 0.19 & 0.18 & 252 & 187 \\
\hline 2 & 0.24 & 0.24 & 207 & 134 \\
\hline 3 & 0.27 & 0.26 & 144 & 115 \\
\hline 4 & 0.22 & 0.21 & 128 & 101 \\
\hline 5 & 0.24 & 0.24 & 126 & 69 \\
\hline 6 & 0.25 & 0.25 & 127 & 104 \\
\hline
\end{tabular}


source of acid loss. After the initial runs, the batching calculation (See Appendix C) was modified and the target was hit. Due to a miscalculation, a lower amount of formic acid was added in runs 4 and $4 \mathrm{H}$, resulting in the lower product acids.

The addition of the $1.47 \mathrm{wt} \%$ copper solution targeted a $475 \mathrm{ppm}$ copper PHA product. Table 6 lists the soluble copper level in the PHA product for each of the twelve runs. For each process, the soluble copper level in the PHA falls with each subsequent run until an apparent steady state value is reached. $\mathrm{Cu}^{+2}$ (soluble) is known to form $\mathrm{Cu}_{2} \mathrm{O}$ (insoluble) during the five-hour $90^{\circ} \mathrm{C}$ hold time, causing a decrease in the soluble copper by the end of the run. In the large PHA heel process, the use of a heel with a diminished soluble copper level would lead to a steady state final soluble copper level less than $475 \mathrm{ppm}$. In the small PHA heel runs, the copper level should remain consistent (since the heel copper level should remain constant). However, note that the trend for the small PHA heel runs is almost identical to that of the large PHA heel runs, indicating some effect of the back to back runs on the steady state soluble copper level.

Only PHA samples from runs 6 and $6 \mathrm{H}$ were analyzed for total copper, soluble copper, and $\mathrm{Cu}^{+1}$. The total copper results were determined by ICP-ES after microwave

Table 7 - Cu Distribution in Final Product

\begin{tabular}{|l|c|c|c|}
\hline Run & $\mathbf{C u}$ (ins) & $\mathbf{C u}^{+\mathbf{1}}$ & $\mathbf{C u}^{\mathbf{+ 2}}$ \\
\hline & $m g / L$ & $m g / L$ & $m g / L$ \\
\hline 6 & 593 & 10 & 77 \\
\hline $6 \mathrm{H}$ & 540 & 10 & 88 \\
\hline
\end{tabular}

digestion. The $\mathrm{Cu}^{+1}$ was measured by spectrophotometric absorbance at 454 $\mathrm{nm}$ after reacting with bathocuproin. Table 7 shows the calculated distribution of $\mathrm{Cu}$ (insoluble), $\mathrm{Cu}^{+1}$, and $\mathrm{Cu}^{+2}$. Note that most of the copper is insoluble. Of the copper present, much more $\mathrm{Cu}^{+2}$ is present than $\mathrm{Cu}^{+1}$. It is apparent that the cupric ion is being reduced during processing, although this did not seem to affect the rate of PBA destruction.

\section{PBA Kinetics}

Samples were pulled every hour during the $90^{\circ} \mathrm{C}$ hold and analyzed for phenylboric acid (PBA) using a liquid chromatograph. Figure 2 shows the destruction curves for each run.

Figure 2 - PBA Destruction During the Five-hour Hold

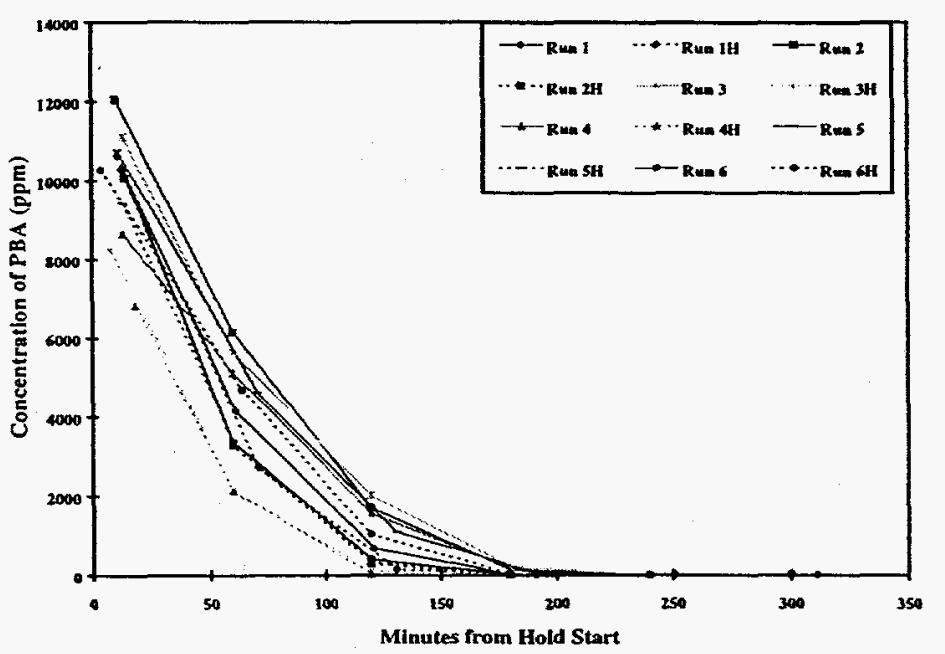

All of the runs were successful in destroying the PBA in less than five hours. The diphenyl mercury was also destroyed well within the five-hour $90^{\circ} \mathrm{C}$ hold time period. Appendix B contains the High Pressure Liquid Chromatography (HPLC) data. 
Table 8 lists the PBA destruction rate constants for each of the runs in $\mathrm{hr}^{-1}$. See Appendix $\mathrm{C}$ for the calculations. Run sequence did not seem to have an effect on the reaction speed, but the large PHA heel process destroyed the PBA faster than the current DWPF process (despite the lower soluble copper level). All of the runs destroyed the PBA in less than three hours. The diphenyl mercury was destroyed in less than five hours. It should be noted that the precipitate for each run was isolated separately before the runs started. This was done for four runs at a time (two for each process). If the runs

Table 8 - PBA Destruction Rate Constants, $\mathrm{hr}^{-1}$

\begin{tabular}{|c|c|c|}
\hline Run & Small PHA Heel & Large PHA Heel \\
\hline 1 & 1.52 & 2.15 \\
\hline 2 & 1.57 & 2.05 \\
\hline 3 & 1.37 & 2.40 \\
\hline 4 & 1.39 & 3.52 \\
\hline 5 & 1.63 & 1.92 \\
\hline 6 & 1.83 & 1.81 \\
\hline Average & 1.33 & 1.98 \\
\hline
\end{tabular}

are looked at in blocks of two, the reaction rates look almost identical for each process (i.e., runs $1 \& 2$ are the same, and runs $1 \mathrm{H} \& 2 \mathrm{H}$ are also the same). This is true for the middle and final sets of runs as well, as a result of similar solids concentration within the sets.

\section{Final Product Solids}

Table 9 lists the total weight percent solids concentration of the PHA product in each of the twelve runs. The large PHA heel product led to a much more concentrated product by the end of six runs. Approximately $99.99 \%$ of the steady state solids concentration has been reached by the sixth run. At these concentrations, 8,600 gallons of the large PHA heel product would feed the same amount of solids to the SRAT as 11,000 gallons of the current SPC product. This should represent a significant timesaving to DWPF.

Table 9 - Total wt \% Solids in PHA Product

\begin{tabular}{|c|c|c|}
\hline Run & Small PHA Heel & Large PHA Heel \\
\hline 1 & 4.20 & 4.31 \\
\hline 2 & 4.31 & 5.15 \\
\hline 3 & 4.26 & 5.44 \\
\hline 4 & 4.18 & 5.38 \\
\hline 5 & 4.30 & 5.48 \\
\hline 6 & 4.34 & 5.53 \\
\hline Delta & 0.14 & 1.22 \\
\hline
\end{tabular}

\section{Decanter Efficiency and Organic Distribution}

Samples of the decanter organic and aqueous and the PHA product were analyzed for high boiling organic content. Appendix B lists the raw data obtained from the HPLC. Figure 3 shows the total amount of organic found in the decanter organic layer as a function of each successive hydrolysis cycle. As expected, the high boiling organic compounds accumulate in the decanter organic over time. The organic layer, as would be expected, has a significantly higher amount of high boiling organic compounds than the PHA product. However, in the organic layer the total amount continues to increase from run to run. As a qualitative measure, this pattern demonstrates the efficiency of the 
Westinghouse Savannah River Company

WSRC-TR-97-00390

Savannah River Technology Center

Revision 0

decanter. However, the decanter was not scaled by cross sectional area (which would have required a diameter of $1 / 16^{\text {th }}$ inch), so a comparison to the DWPF decanters is unrealistic.

Figure 3 - Organic Content of Decanter Organic

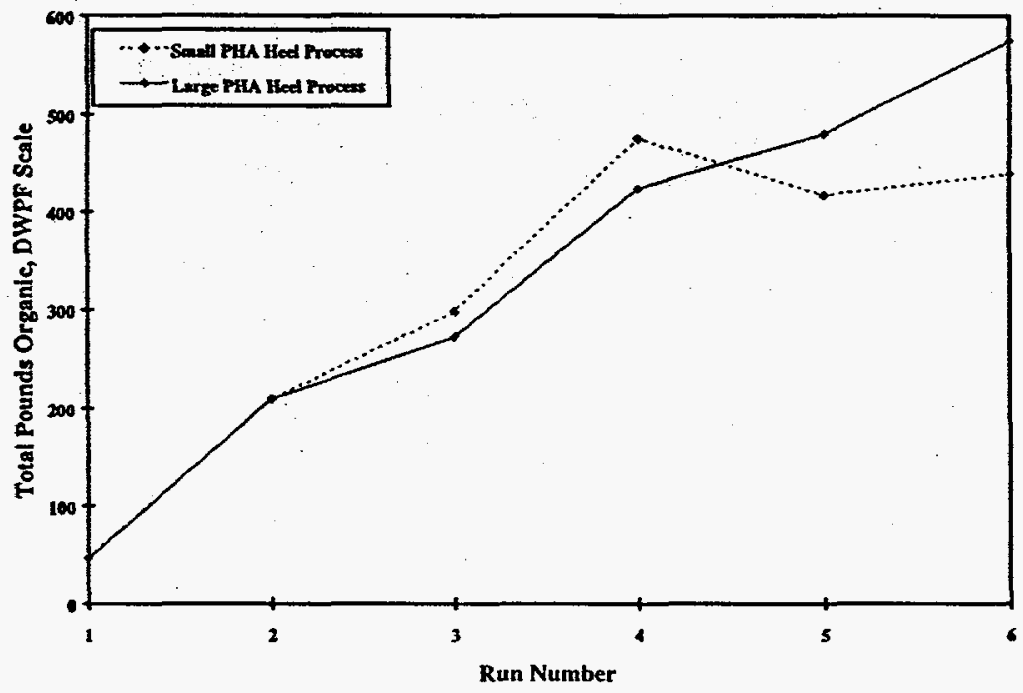

2

Figure 4 plots the total amount of organic found in the PHA product and the aqueous decanter layers. The organic concentration in the PHA product seems to remain constant over time in both the current process and the large PHA heel process.

Figure 4 - Organic Content in Aqueous Products

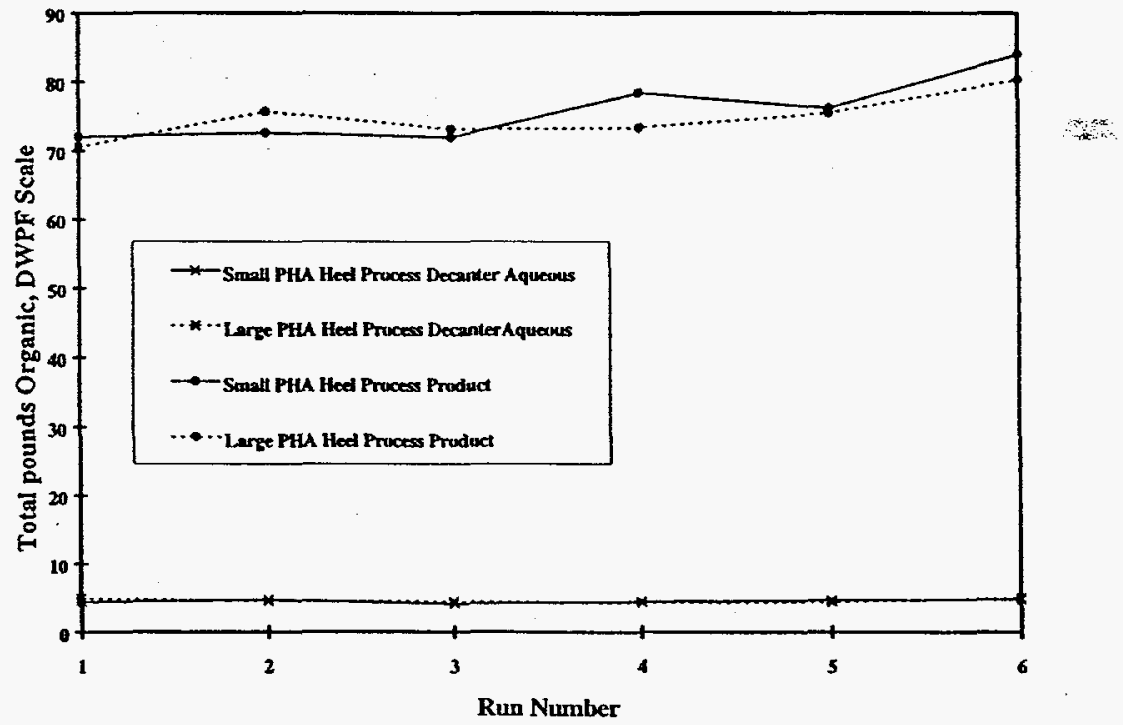

To compare the organic distribution in both runs, a paired $t$-test was performed for each high boiling organic compound measured in each product stream (total grams in the PHA, decanter organic, and decanter aqueous) over the six runs. Appendix $C$ contains the data 
from this study. There were no statistical differences at the $5 \%$ confidence level in the absolute amount of organic in any of the streams except for the product levels of diphenylamine, phenol, and m-terphenyl. The mean differences for these three data streams were $0.749 \mathrm{lbs}, 2.743 \mathrm{lbs}$ and $-0.293 \mathrm{lbs}$, respectively. Such small differences will not have a practical significance for DWPF processing. The least significant. differences for the results also indicate that the sensitivity of the statistical methods used were sufficient to recognize differences of practical concern. Overall, the large PHA heel process produced $1 \%$ less total organic mass in the PHA as observed in these studies.

\section{Offgas}

A gas chromatograph monitored the generation of hydrogen and carbon dioxide throughout the runs. Appendix B contains the raw data from the GC. The total outlet flow was calculated using the argon internal standard, and offgas production was scaled to a 6,000-gallon PHA batch. Figure 5 shows the observed carbon dioxide levels for each of the runs. Figure 6 and Figure 7 show the hydrogen generation rates in the small PHA heel and the large PHA heel process runs respectively. Sister runs (same sequence number, "L" representing the large PHA heel process) are represented by the same color with the PHA heel run having a dotted line (i.e. Run 1 - small PHA heel, run 1L - large PHA heel). The right $y$-axis represents the concentration in the vapor effluent as measured by the GC. The left y-axis represents the mass flow scaled to a 4500 gallon precipitate batch. Time zero on the $\mathrm{x}$-axis designates the beginning of the 5 -hour $90^{\circ} \mathrm{C}$ hold time in each run. The times were adjusted so that all of the holds $\left(90^{\circ} \mathrm{C}\right.$ and boiling) are exactly 5 hours and all of the heat up times from 90 to boiling are 36 minutes.

Figure 5 shows the carbon dioxide production during each run. The baseline $\mathrm{CO}_{2}$, the amount used to purge the vessel, is also displayed on the graph. The volume \% numbers above $100 \%$ in Run 1 resulted from a miscalibration of the GC. For the rest of the runs, $\mathrm{CO}_{2}$ production is highest during feeding, levels off during the $90^{\circ} \mathrm{C}$ hold, peaks at the onset of boiling, and tapers down toward the baseline as boiling continues. The acid base reaction takes place during feeding, causing the $\mathrm{CO}_{2}$ to rise. 


\section{Figure 5 - $\mathrm{CO}_{2}$ Generation During Process Demonstrătion Runs}

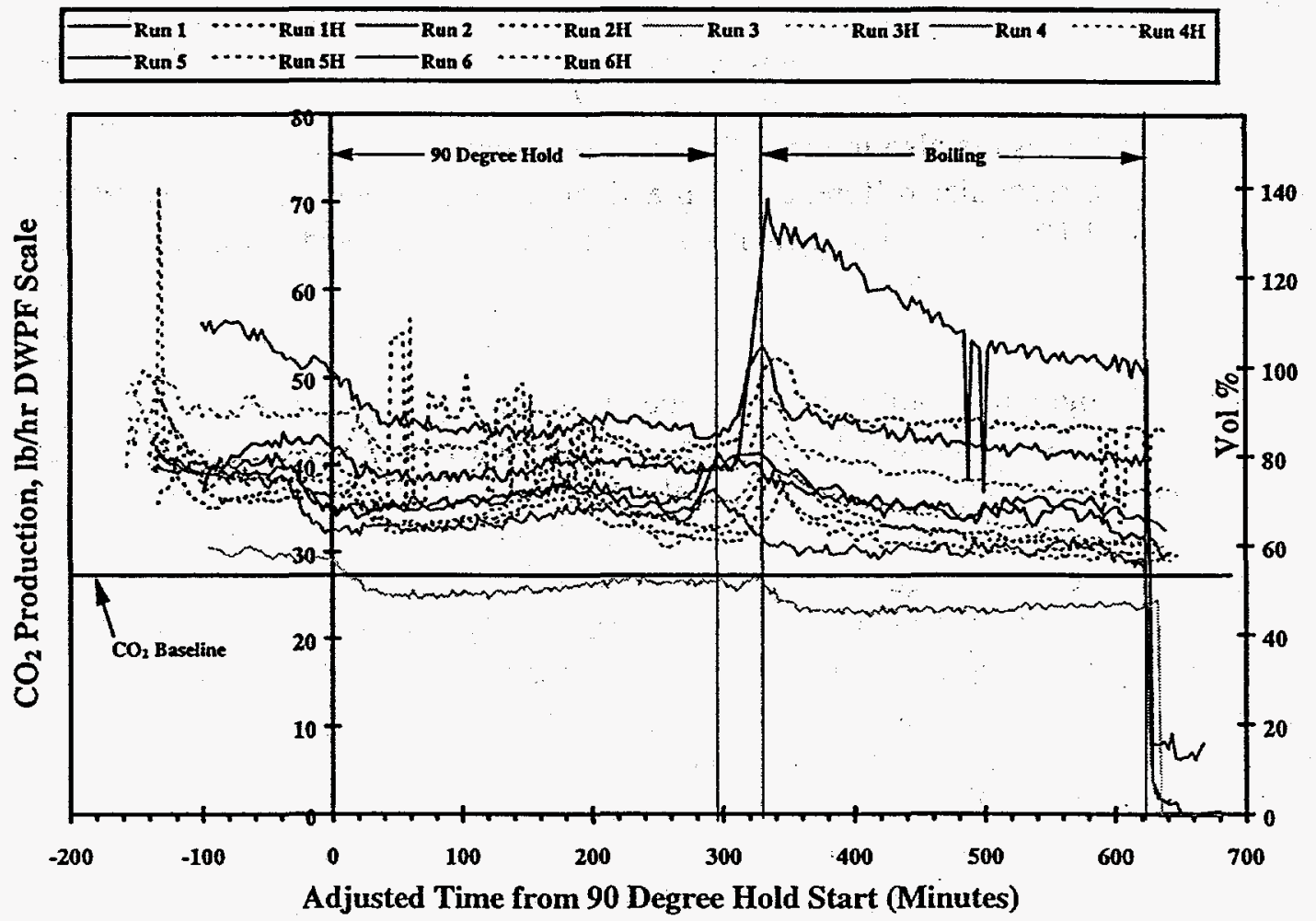

Figure 6 shows the hydrogen generation rate during the small PHA heel runs as a function of time into the hydrolysis cycle. In each run, the rate of hydrogen generation increases during the feed cycle as would be expected. During the five-hour hold period at $90^{\circ} \mathrm{C}$, the rate of hydrogen generation peaks in each run and then begins to gradually fall off. With the onset of boiling, the rate of hydrogen generation increases quite rapidly, peaking early into the boil cycle and then with the exception of Run 6 gradually declines. In Run 6 the rate of hydrogen generation appears to begin to increase again after about 4 hours into the 5-hour boil cycle. Of particular significance is the tendency for the peak hydrogen rate to be higher with each successive run. As seen in Figure 7, this tendency is even more pronounced in the Large PHA heel process simulations. 
Figure 6 - Small PHA Heel Process Hydrogen Generation

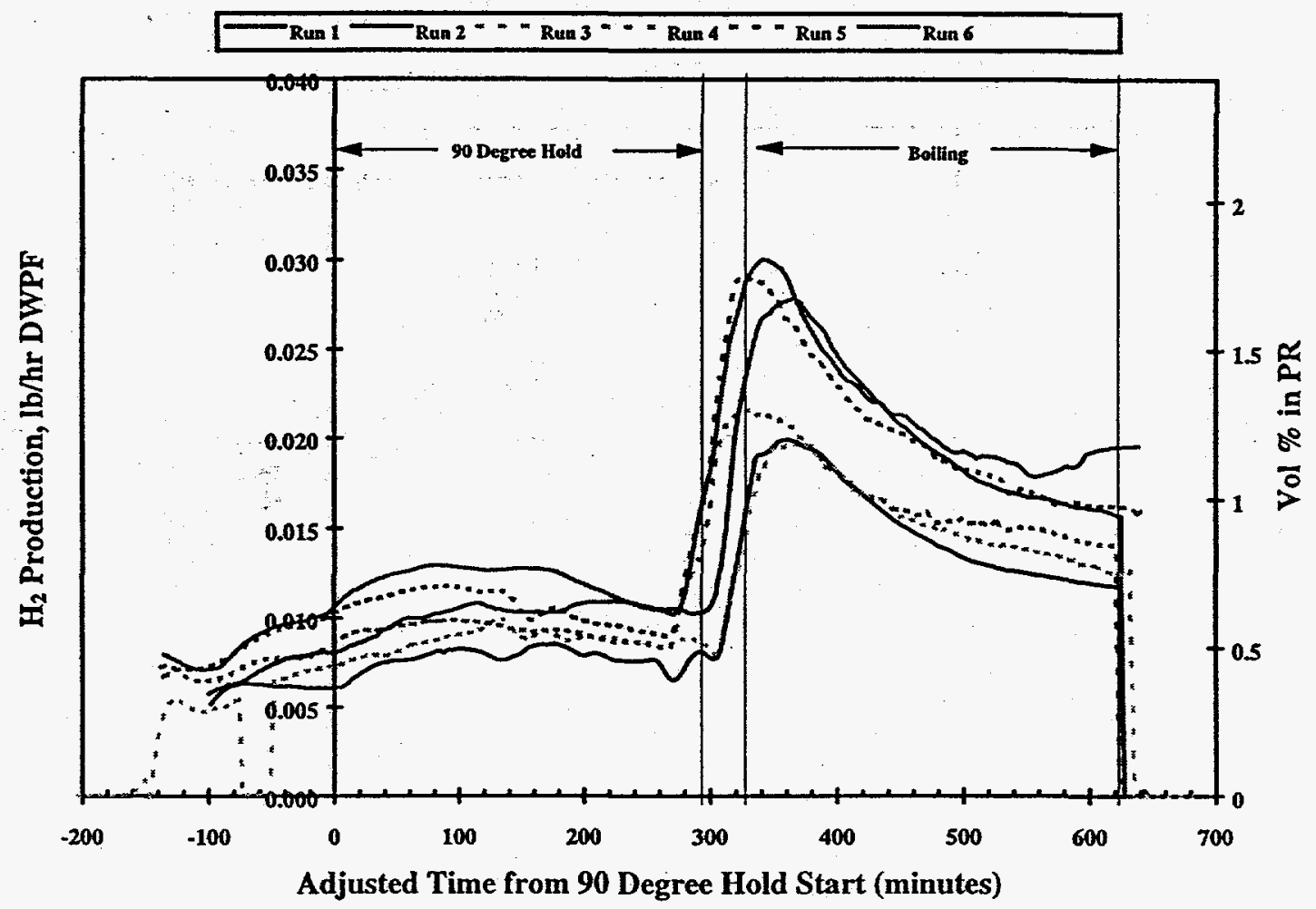

Figure 7 illustrates the stairstep effect of hydrogen generation during each sequential run. The last three large PHA Heel runs show a significant second peak during the five-hour boil, which gets higher for each sequential run. Both the last two runs (5L and $6 \mathrm{~L}$ ) exhibited a second $\mathrm{H}_{2}$ peak (even greater than that observed at the onset of boiling), nearly reaching a $\mathrm{H}_{2}$ concentration of $2.5 \mathrm{vol} \%$ in the PR. Even in runs $3 \mathrm{~L}$ and $4 \mathrm{~L}$, the rate of hydrogen generation has begun to increase before the end of the five-hour boil. 
Figure 7 - Large PHA Heel Process Hydrogen Generation

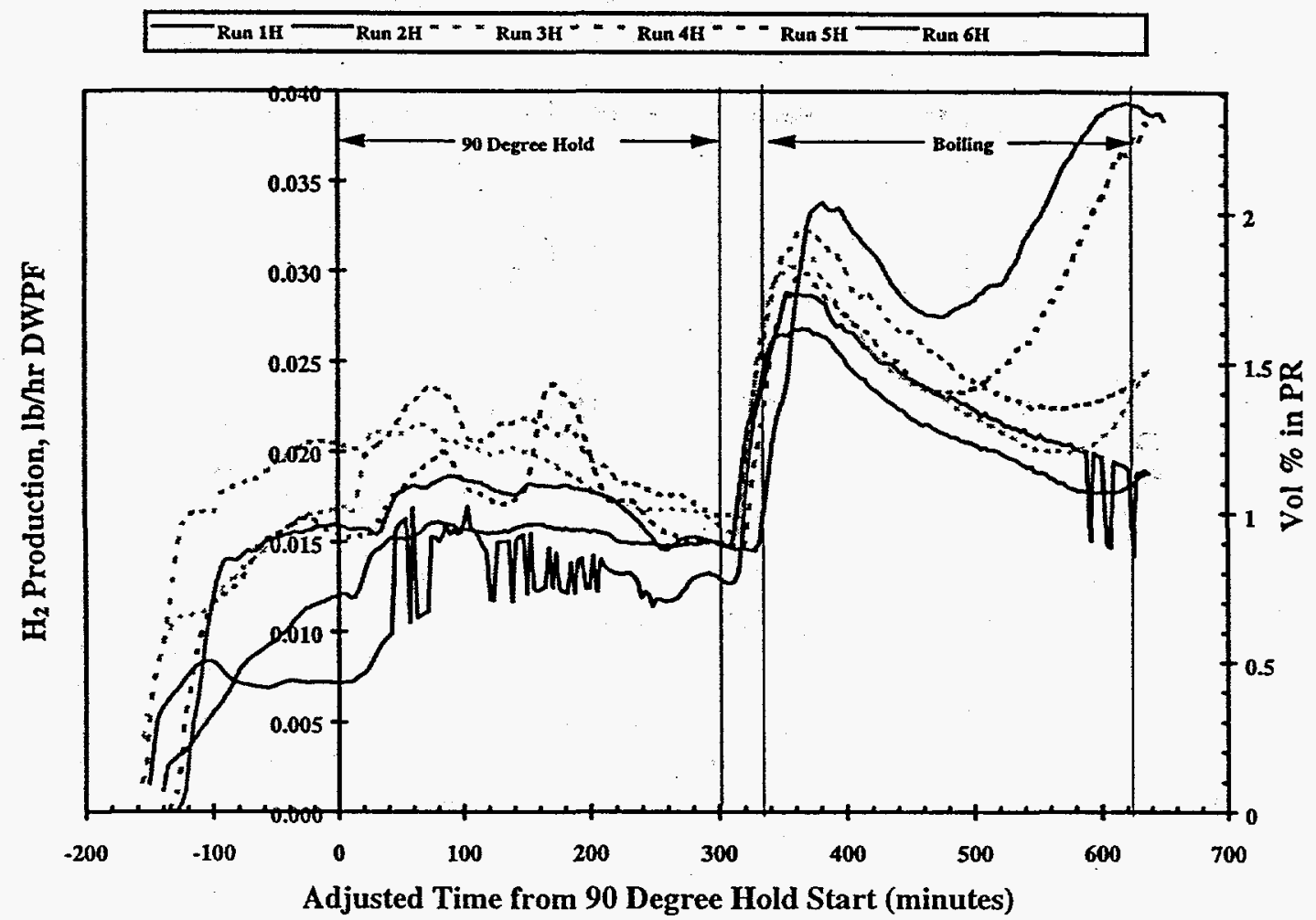

\section{Explanation of Increasing Hydrogen}

Several mechanisms were considered to explain the sequential increase in the rate of hydrogen generation. The total precipitate solids concentration in each run increased from $10.2 \%$ to about $10.9 \%$, due to evaporation, so more solids were fed in each subsequent run. However, the slight concentration increase $(6.4 \%)$ is not enough to explain the $108 \%$ increase in the hydrogen peak for the large PHA heel runs. An accumulation in noble metals during the runs was considered a more likely explanation. Three possible mechanisms for the accumulation of noble metals in the reactor were considered. First, some fraction of the noble metals in each batch may have plated out on the surface of the reactor. The second postulated mechanism was an increase in insoluble solids in the reactor heel with each successive run, since at the end of each run, the entire contents of the reactor were pumped out to a carboy. Although the agitator was left on throughout the transfer, the PHA level falls below the level of the agitator before the transfer is complete. During this final stage of the transfer, some solids could have accumulated in the bottom of the reactor.

To investigate these theories, a number of additional experiments were run. In each of five runs, either a $0.25 \mathrm{M}$ formic/475 ppm copper solution or the large PHA heel product (combination of all the runs) was boiled for five hours while the offgas was monitored. Figure 8 shows the hydrogen generation profile for each of these runs. 
To establish a baseline, the formic acid/copper solution was boiled in a clean glass kettle. Minimal hydrogen was measured. The next experiment boiled PHA in the dirty kettle used during the large PHA heel process runs. A large peak was observed at boiling, and the level dropped consistently over the five hours aqueous boil period. The third experiment boiled PHA in a clean glass kettle. The peak for the PHA in the stainless kettle was higher at boiling, but the average generation over the last 200 minutes for the runs was identical. These runs presented strong evidence that the PHA solids are responsible for the hydrogen generation.

The fourth experiment boiled the formic acid/copper solution in the dirty kettle used in the water heel process runs. The amount of hydrogen generated in this run was significantly higher than that of the same solution boiled in the clean glass kettle. Because the magnitude of difference was so large, another experiment was done after rinsing the kettle as thoroughly as possible with water. A large amount of solids was noted in the wash water form the kettle. In the last experiment, where formic acid/copper was boiled in the rinsed stainless kettle, a lower amount of hydrogen was measured, although still much higher that that in the clean glass kettle.

Figure 8 - Hydrogen Generation in Further Studies

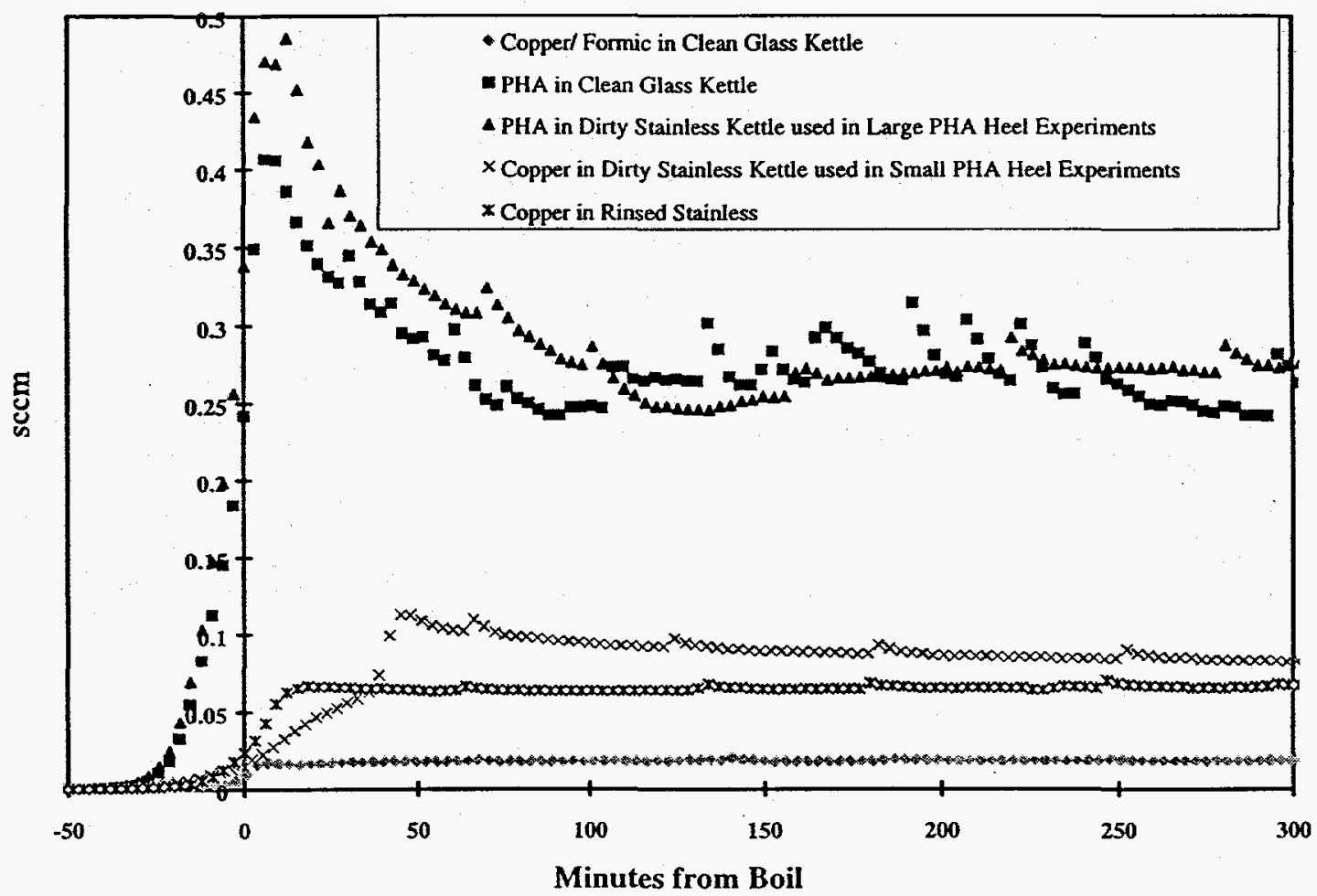

The results from these five experiments strongly supported the postulated mechanism that the noble metals (i. e. sludge solids) content of the large PHA heel in each successive run was increasing. 
As previously described, PHA was not being agitated during the transfer of the PHA from the reactor to the carboy when the liquid level dropped below the agitator, which led to a conclusion that some noble metals and other insoluble species were left behind during the transfer. A second series of large PHA heel experiments was completed in which the PHA was not completely pumped out of the kettle and agitation was maintained throughout the transfer. A minimum of three additional experiments was planned. As a result of problems in experiments 2 and 3, a total of seven experiments were completed. These experiments were conducted in a one-liter kettle to enable conducting the necessary experiments with the small amount of precipitate feed remaining. Each experiment included approximately 2.5 hours of feeding, five hours of $90^{\circ} \mathrm{C}$ hold, and five hours of aqueous boil.

The hydrogen generation rate in each of these seven tests (designated as Test 1-7) is summarized in Table 10 . The peak hydrogen rates are based on a 4,500-gallon precipitate batch. The important observations to be made from these seven tests are (1) the absence of increasingly higher peak hydrogen generation rate with each successive test (lending credibility to the second postulated mechanism to explain the increase in hydrogen generation with each successive run observed in the Phase II experiments) and (2) the absence of a second hydrogen peak during the boil cycle which was observed in the last two large PHA heel experiments in Phase II. Figure 9 shows the hydrogen generation rate profiles as a function of time into the hydrolysis cycle for each of the even tests.

Table 10 - Hydrogen Peak Comparison

\begin{tabular}{|c|c|c|c|}
\hline New Runs & $\begin{array}{l}\text { Hydrogen Peak, } \\
\text { lb/hr } 6000 \text { gal batch }\end{array}$ & $\begin{array}{l}\text { Original Phase II } \\
\text { Runs }\end{array}$ & $\begin{array}{l}\text { Hydrogen Peak, } \\
\text { lb/hr } 6000 \text { gal batch }\end{array}$ \\
\hline Test 1 & 0.0212 & Large PHA Heel 1 & 0.0288 \\
\hline Test 2 & 0.0287 & Large PHA Heel 2 & 0.0268 \\
\hline Test 3 & 0.0215 & Large PHA Heel 3 & 0.0309 \\
\hline Test 4 & 0.0251 & Large PHA Heel 4 & 0.0323 \\
\hline Test 5 & 0.0296 & Large PHA Heel 5 & 0.0383 \\
\hline Test 6 & 0.0298 & Large PHA Heel 6 & 0.0394 \\
\hline & 0028 & & \\
\hline
\end{tabular}


Figure 9 - Hydrogen Generation During Tests 1-7

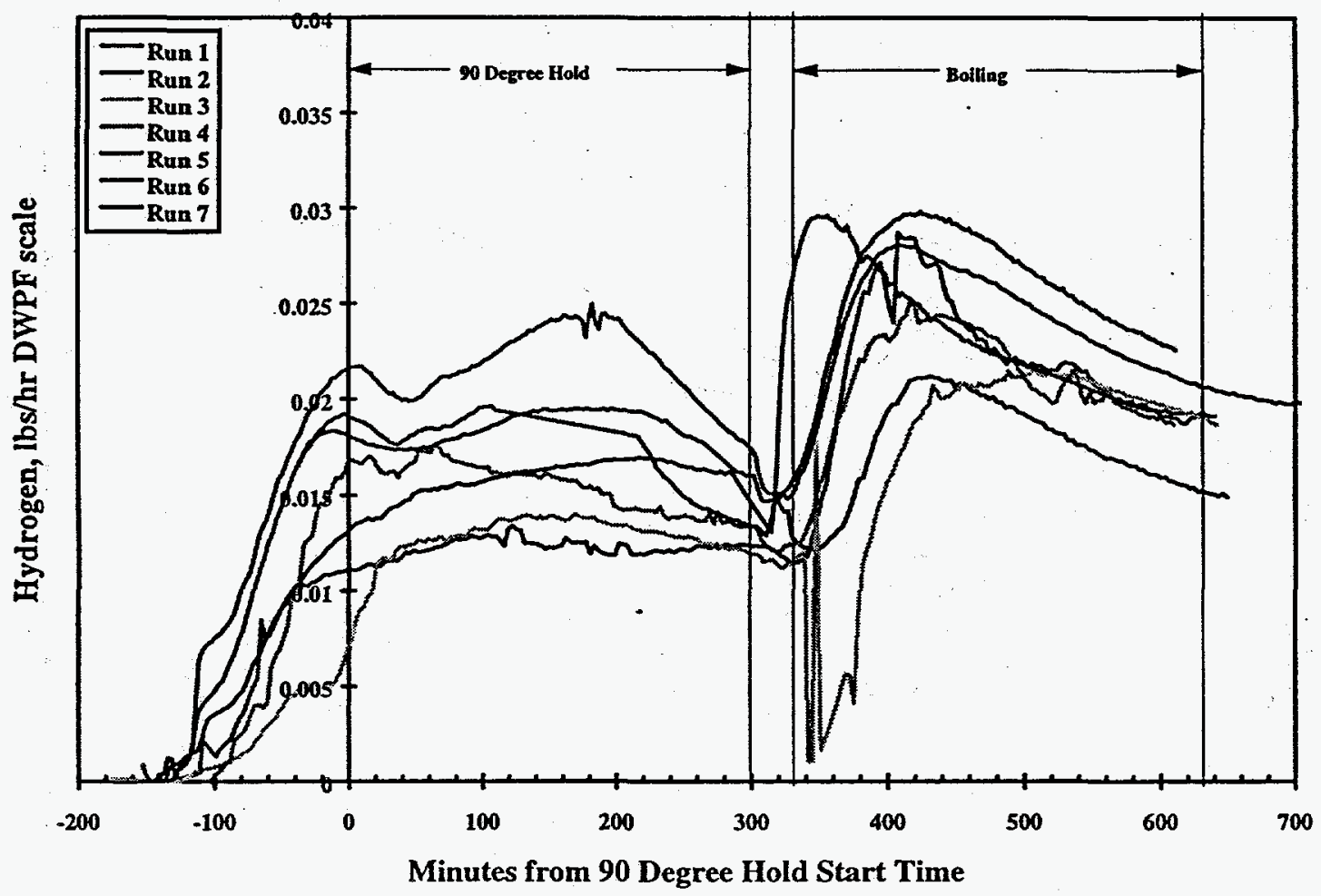

Figure 10 shows the hydrogen peaks for all the large PHA Heel Flowsheet development runs. The "Small PHA Heel" runs are the first six experiments using the existing late wash flowsheet. The "Large PHA Heel" runs are the six original PHA Heel runs in the 4 L stainless kettle. The "PHA Heel Tests 1-7" runs are the seven additional PHA Heel runs in the one-liter Hastelloy kettle conducted to support the postulate mechanisms of increasingly higher noble metal concentration. in each successive PHA heel Phase II experiments. Note that the hydrogen trend for the original small PHA heel run is very similar to the hydrogen trend in the further study PHA heel runs. 


\section{Figure 10 - Hydrogen Peak: Values}

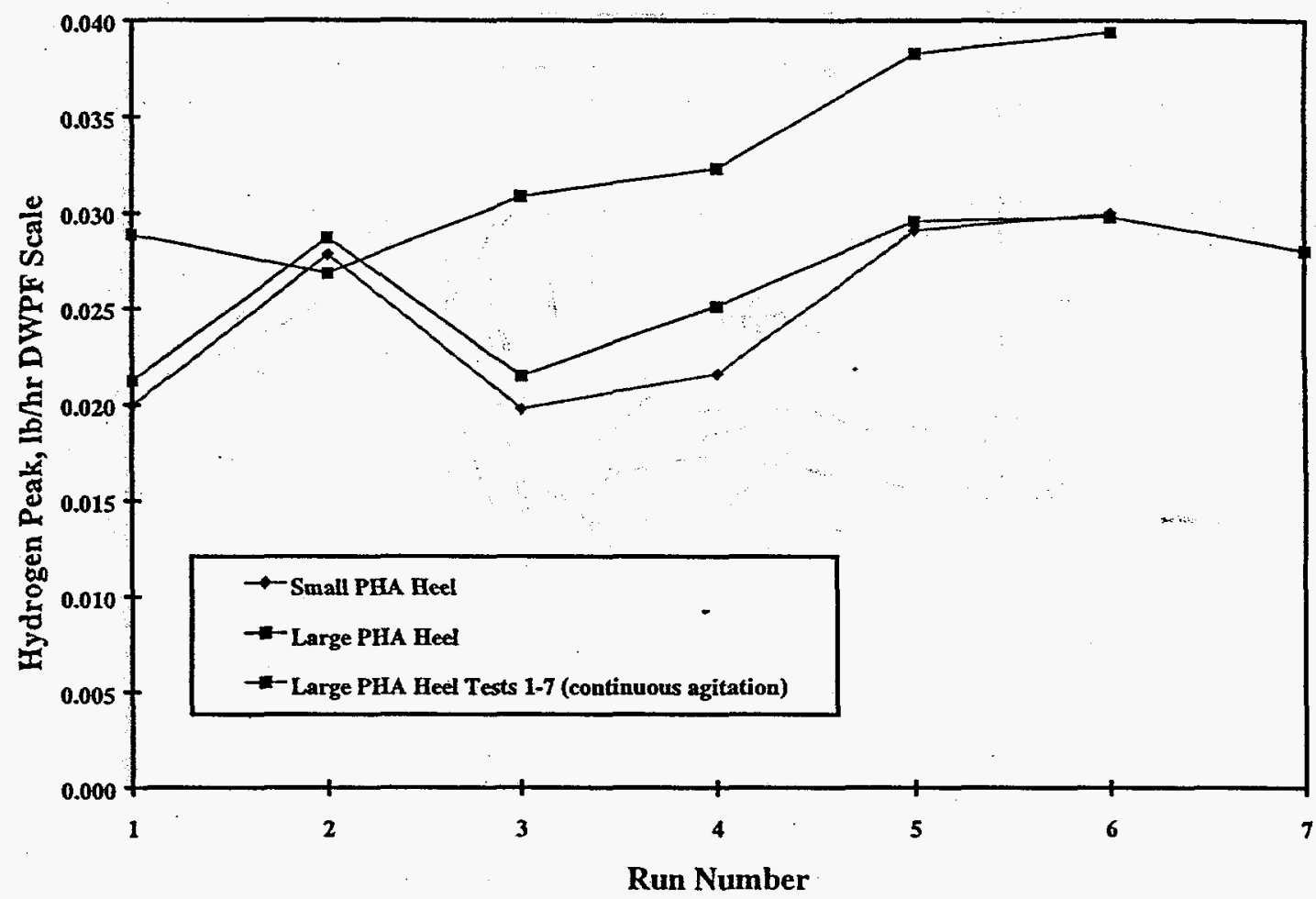

A computational study was performed to investigate the similarity between the water heel process runs and the large PHA Heel Further Studies runs. A worst case scenario was set up assuming that all of the noble metals contained in the PHA solution below the agitator line were left behind in the kettle. (Appendix $\mathrm{C}$ contains the details of this calculation). Table. 11 compares the predicted values obtained for the ratio of noble metals to the actual ratio of the hydrogen peak for each of the three processing scenarios. Note that the predicted ratio uses the average run 1 value of all three runs. The predicted values correspond well with the actual hydrogen ratios, which implies a strong correlation between the noble metals and the hydrogen production. This also shows that the solids settling in the kettle theory (second postulated mechanism) is most likely correct. Because the prediction shows a steady increase in noble metals concentration that reaches a steady state around the $6^{\text {th }}$ run, the hydrogen level observed at the $6^{\text {th }}$ run should be the highest value seen, if the settling is the only factor in the increasing levels.

Table 11 - Computational Study Results

\begin{tabular}{|c|c|c|}
\hline \multicolumn{2}{|c|}{$\begin{array}{c}\text { Predicted Ratio of Noble } \\
\text { Metals (Run 6/Run 1) }\end{array}$} & $\begin{array}{c}\text { Actual Ratio of H } 2 \text { Peak } \\
\text { (Run 6/Average Run 1) }\end{array}$ \\
\hline Small PHA Heel Process & 1.25 & 1.23 \\
\hline Large PHA Heel Process & 1.63 & 1.62 \\
\hline Large PHA Heel Tests 1-7 & 1.23 & 1.22 \\
\hline
\end{tabular}

A few additional experiments were performed to determine if noble metals plating out on the kettle is a concern. Before the start of the runs, a $0.25 \mathrm{M}$ formic acid $/ 475 \mathrm{ppm} \mathrm{Cu}$ solution was boiled in the one-liter Hastelloy kettle, and the hydrogen generation measured. 
Figure 11 is a graph of hydrogen generation in experiments with clean and dirty kettles. Note that the runs with dirty kettles had significantly higher hydrogen generation rates versus the clean glass and Hastelloy kettles. Cleaning the kettle out after the runs did reduce the hydrogen generation. Two cleaning methods, scraping solids and cleaning with water, were equally effective in lowering the hydrogen. Cleaning with acetonitrile and acetone was even more effective, although the original hydrogen level was never achieved after cleaning (although it was significantly reduced with the solvent cleaning). Although it would be impossible to completely remove the solids from the kettle, the level of hydrogen generation after solvent cleaning does imply that noble metal plating may contribute slightly to the increasing hydrogen.

Figure 11 - Formic Acid/Copper Solution Boiled in Kettle

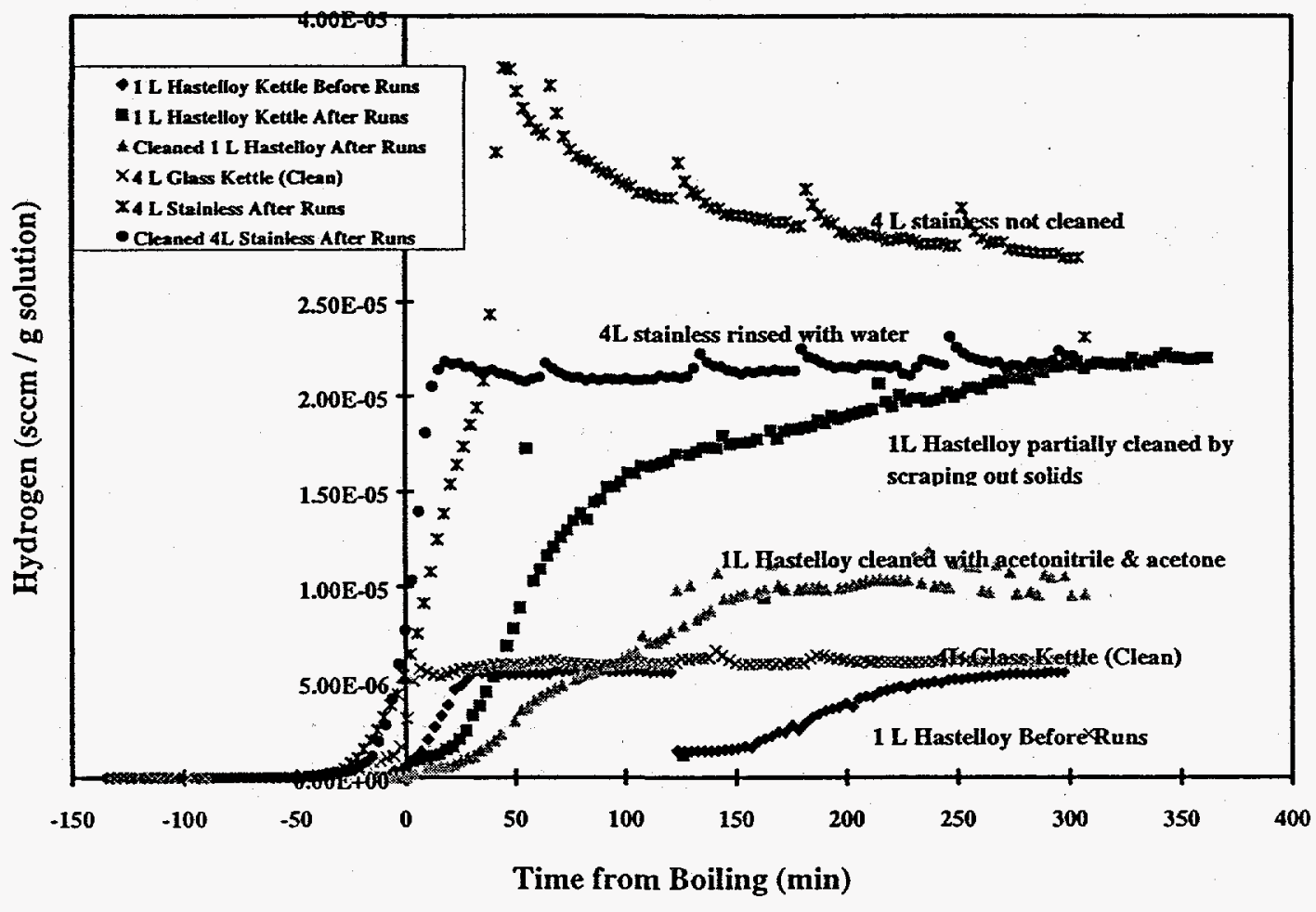


Westinghouse Savannah River Company

WSRC-TR-97-00390

Savannah River Technology Center

Revision 0

\section{IMPACT ON ORGANIC EVAPORATOR CYCLE}

The current Salt Processing Cell flowsheet includes decontamination of the organic recovered from the PR cycle. This is accomplished in the Organic Evaporator (OE). Each batch of organic recovered from the PR cycle is washed with water in the $\mathrm{OE}$ and the washed organic is then distilled to the Organic Hold Tank (OHT) and if within radionuclide concentration limits ultimately transferred to the Organic Waste Storage Tank (OWST) located outside the DWPF building. The aqueous wash remaining in the $\mathrm{OE}$ is transferred to the PR and becomes a part of the PR heel for the next PR cycle.

If it is necessary to continue this practice with the recommended large PHA heel flowsheet, the advantages of a heel made up solely of PHA will not be fully realized. For example, the solids content of the PHA would be less than if the heel was entirely made up of PHA and accordingly the PHA batch size for transfer to the SRAT would be larger. To maximize the benefits of the proposed modification to the current SPC flowsheet, it must be determined how many $\mathrm{OE}$ cycles can be performed without the need to recycle the $\mathrm{OE}$ bottoms to the PR. This would likely be contingent on how many OE cycles may be performed before the radioactivity limit in the organic recovered form the $\mathrm{OE}$ cycle is compromised and whether at this point the accumulation of organic high boilers in the OE would present a problem upon recycle to the PR.

\section{RECOMMENDATIONS FOR ADDITIONAL STUDIES}

- Determine the maximum number of $\mathrm{OE}$ cycles that can be performed before it is necessary to recycle the bottoms to the $\mathrm{OE}$ and determine if the compositional makeup of the OE recycle would present any problems in the Chemical Process Cell.

- Conduct a process simulation of the large PHA heel flowsheet on a larger scale to determine if the potential for accumulation of noble metal bearing solids exists from run to run due to inadequate agitation. The proposed $1 / 240^{\text {th }}$ scale SRAT unit to be installed should be appropriate.

- Conduct additional bench-scale large PHA heel hydrolysis process simulations, varying bounding key KTPB parameters such as noble metal content of sludge solids, nitrite concentration, diphenylmercury concentration etc., that should enable development of a better hydrogen peak/noble metal level correlation.

- Conduct successive SRAT cycles with key parameters scaled from current DWPF SRAT cycle operating parameters including the addition of a SRAT heel in each run to determine if the is an increase in peak hydrogen generation with each successive SRAT cycle.

- Irradiate the organic deposits left on the kettle and analyze the irradiated compounds. The effect on the radiation field on the high boiling organic compounds should be investigated, since all experiments in this report were non-radioactive. 
Westinghouse Savannah River Company

Savannah River Technology Center

WSRC-TR-97-00390

Revision 0

\section{LIMITATIONS OF SMALL SCALE TESTING WITH SIMULANTS}

There are some important processing attributes in small scale testing with simulants that differ from DWPF. The following differences are noted:

1. All experiments used a nonradioactive irradiated precipitate feed simulant.

2. An electric heating mantle was used to heat the vessels in the small scale experiments as opposed to the steam coils in DWPF. Because of the geometry of the laboratory equipment, the scaled boilup rate $(\mathrm{b} / \mathrm{hr})$ was achieved but not the boilup flux $(\mathrm{b} / \mathrm{hr} / \mathrm{area}$ of liquid surface.)

\section{ACKNOWLEDGEMENTS}

Thanks to Frances Williams, whose many hours of technical coverage (and working with our Gas Chromatographs) were invaluable to the success of these experiments.

A special thanks to the ITS technicians, Sammie King, John Duvall, Mary Johnson, Vickie Williams, for their hard work in accomplishing these runs. In addition to working shifts to provide coverage throughout the runs, they set up equipment, calibrated analyzers, prepared chemicals, and performed analytical work to support this study. Thanks also to Shumei Lee, who also provided technical coverage during the runs.

Thanks to Grace Shu and Curtis Johnson for their assistance in completing the analytical work during the runs. Thanks especially to Tom White and Annie Still for their HPLC work.

Thanks to Tommy Edwards, who provided the statistical support and completed the statistical study. Thanks also to Paul Monson, Russ Eibling and Jim Marek, who provided technical insight throughout the study. 
Westinghouse Savannah River Company

WSRC-TR-97-00390

Savannah River Techṇology Center

Revision 0

\section{REFERENCES}

' J. C. Marek, Hydrolysis of Late-Washed, Irradiated Tetraphenylborate Slurry Simulants II: Noble Metal Catalyzed Hydrogen Generation Rates (U), WSRC-TR-95-0100, March 22, 1995

${ }^{2}$ M. A. Baich, R. A. Jacobs, J. C. Marek, J. Morrison, H. B. Shah, and S. R. Young., Technical Basis for HAN Precipitate Hydrolysis Process, WSRC-TM-90-11, December 1990

${ }^{3}$ Technical Bases for the Nitric Acid Flowsheet (U), WSRC-TR-92-480, October 26, 1992

4 R. A. Jacobs, D. F. Brown, A. S. Choi, H. H. Elder, J. R. Fowler, J. M. Gillam, and M. R. Poirier, "DWPF Recycle Minimization - Final Report (U)," WSRC-TR-93-0677, Rev, 0, December 20, 1993

5 HLW/DWPF/TTR-970117

${ }^{6}$ K. G. Brown, C. M. Jantzen, and J. B. Pickett, The Effects of Formate and Nitrate on Reduction/Oxidation (Redox) Process Control for the Defense Waste Processing Facility (DWPF) (U), WSRC-RP-97-34, February 5, 1997

7 J. A. Ritter, Hydrogen Generation During IDMS Demonstrations of the Late Washing and Nitric Acid Flowsheets (U), WSRC-RP-92-1237, October 19, 1992

${ }^{8}$ C. W. Hsu, Summary Report: Hydrogen Generation in SRAT with Nitric Acid and Late Washing Flowsheets (U), WSRC-RP-1236, October 2, 1992

9 J. R. Zamecnik, Determination of the maximum rate of Hydrogen Generation from the DWPF SME for the Nitric Acid Flowsheet with Late Wash PHA, X-CLC-S-00021

${ }^{10} \mathrm{~K}$. G. Brown, C. M. Jantzen, and J. B. Pickett, The Effects of Formate and Nitrate on Reduction /Oxidation (Redox) Process Control for the Defense Waste Processing Facility (DWPF) (U), WSRC-RP-97-34, February 5, 1997

11 C. J . Bannochie, J. C. Marek, R. E. Eibling, and M. A. Baich, Factors Affecting the Rate of Hydrolysis of Phenylboronic Acid in the Laboratory-Scale Precipitate Reactor Studies 
Westinghouse Savannah River Company

WSRC-TR-97-00390

Savannah River Technology Center

Revision 0

APPENDIX A - LABORATORY SETUP AND PROCEDURES 
Westinghouse Savannah River Company

WSRC-TR-97-00390

Savannah River Technology Center

Revision 0

\section{APPENDIX B - LABORATORY DATA}

Appendix B contains the High Pressure Liquid Chromatography (HPLC) data

Appendix B contains the raw data from the GC. 
Westinghouse Savannah River Company

Savannah River Technology Center

WSRC-TR-97-00390

Revision 0

APPENDIX C - BATCH CALCULATIONS

Acid requirements were calculated based on the results of 5 analyses, including TBP content, an acid titration to $\mathrm{pH} 5.5$, total solids, specific gravity, and nitrite content. Appendix $\mathrm{C}$ contains these calculations. 


\section{APPENDICES}

APPENDIX A - EXPERIMENTAL PROCEDURES

LABORATORY SETUP FOR SCOPING RUNS, PROCESS DEMONSTRATION RUNS, AND TESTS 1-7 ...................1

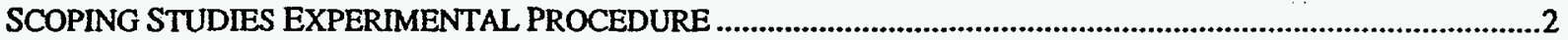

PROCESS DEMONSTRATION EXPERIMENTAL PROCEDURE

PHA HEEL FURTHER STUDIES EXPERIMENTAL PROCEDURE ..................................................................

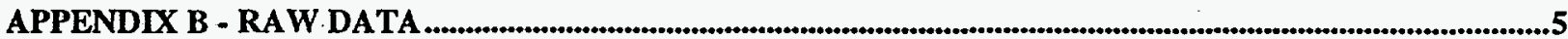

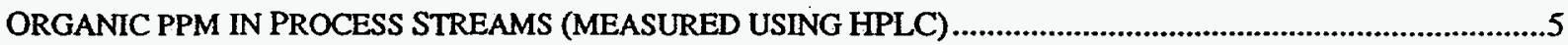

RAW HYDROGEN GAS CHROMATOGRAPH DATA FOR PROCESS DEMONSTRATION EXPERIMENTS................

RAW $\mathrm{CO}_{2}$ GAS CHROMATOGRAPH DATA FOR PROCESS DEMONSTRATION EXPERIMENTS ...........................9

RAW ARGON GAS CHROMATOGRAPH DATA FOR THE PROCESS DEMONSTRATION EXPERIMENTS ............15

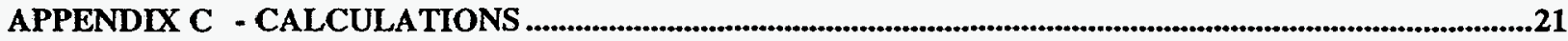

BATCHING CALCULATION FOR THE PROCESS DEMONSTRATION EXPERIMENTS ..........................................21

PHENYLBORONIC ACID DESTRUCTION RATE CONSTANT CALCULATION FOR

THE PROCESS DEMONSTRATION EXPERIMENTS .............................................23

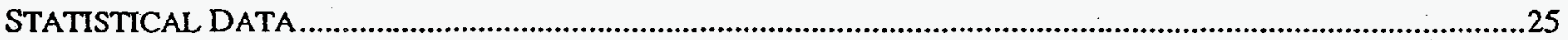




\section{Appendix A - Experimental Procedures}

Laboratory Setup for Scoping Runs, Process Demonstration Runs, and Tests 1-7

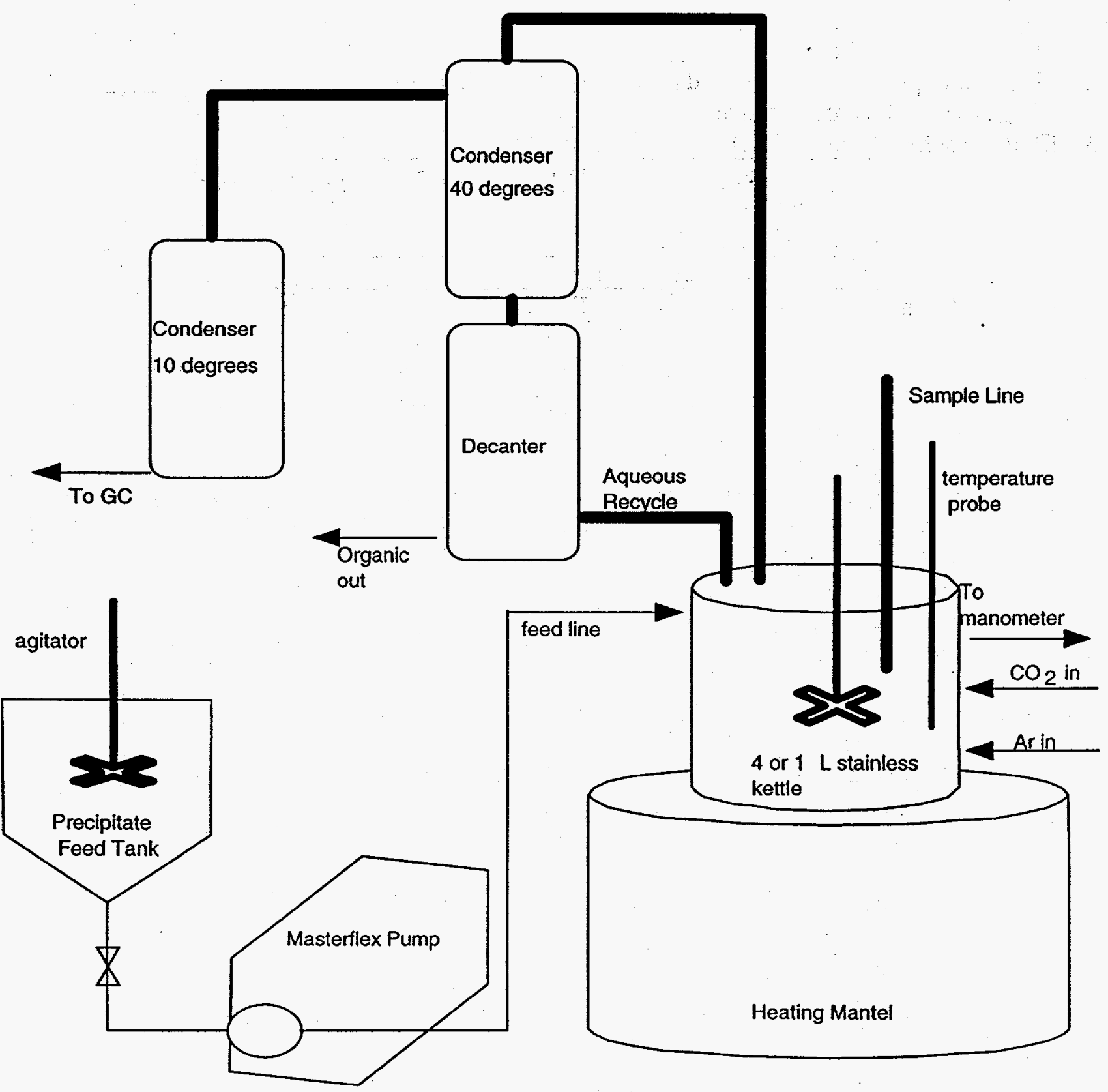




\section{Appendix A - Experimental Procedures}

\section{Scoping Studies Experimental Procedure}

Copper Level

Acid Level

1. Weigh feed carboy." g

2. $\square$ Transfer precipitate to the feed tank. Rinse the carboy with $5.6 \mathrm{~g}$ water. - $g$ used. Weigh feed carboy after transfer g.

3. $\square$ Prepare heel solution in a beaker and sample.

\begin{tabular}{|l|l|l|}
\hline & Desired amount & Actual Amount \\
\hline Heel Solution & & \\
\hline $90 \mathrm{wt} \%$ Formic Acid & & \\
\hline $1.5 \mathrm{wt} \% \mathrm{Cu}$ solution & & \\
\hline
\end{tabular}

4. Transfer the heel solution to the kettle. Flush with $5.6 \mathrm{~g}$ water. $\mathrm{g}$ used.

5. $\square$ Start $\mathrm{CO}_{2}$ purge $3.96 \mathrm{scc} / \mathrm{min}$ on the feed tank and reactor.

6. $\square$ Perform a leak check. Flow reads $\mathrm{scc} / \mathrm{min}$ flow in $=$ flow out

7. Turn $\mathrm{CO}_{2}$ purge of reaction vessel to full scale to sweep out $\mathrm{O}_{2}$. Purge at this high rate for 30-40 min (can be heating vessel during this purge period).

8. $\square$ Turn on agitator. Speed

9. $\square$ Begin heating Pre-reaction heel to $90^{\circ} \mathrm{C}$.

Heat setting Temp setpoint

10. $\square$ When temp reaches $70^{\circ} \mathrm{C}$, set $\mathrm{CO}_{2}$ purge of reactor vessel to $3.96 \mathrm{scc} / \mathrm{min}$ (it was at full range).

11. $\square$ Feed precipitate slurry at $3.8 \mathrm{ml} / \mathrm{min}$ while agitating slurry. Record start time. Record stop time

12. Pull 5-ml Post feed sample (use GLASS sample bottles). Record information below.

\begin{tabular}{|l|l|l|}
\hline Sample Name & Time & Mass \\
\hline SLHPR-1-hold 01 & & \\
\hline SLHPR-1-hold-02 & & \\
\hline SLHPR-1-hold-03 & & \\
\hline SLHPR-1-hold-04 & & \\
\hline SLHPR-1-hold-05 & & \\
\hline SLHPR-1-product & & \\
\hline SLHPR-1-organic & & \\
\hline SLHPR-1-aqueous & & \\
\hline
\end{tabular}

13. $\square$ Hold vessel at $90^{\circ} \mathrm{C}$ for 5 hours. Record hold start time

14. $\square$ Pull additional $5 \mathrm{ml}$ samples every hour. Record information in sample chart. Cool and refrigerate these samples promptly.

15. Turn off power to mantle. Record hold stop time

16. $\square$ Transfer PHA into tared 1 Liter glass bottle.

17. $\square$ Turn off all instruments and gas flows. 


\section{Appendix A - Experimental Procedures}

\section{Process Demonstration Experimental Procedure}

1. $\square$ Transfer 80 grams each of aqueous and organic from the last run to the decanter. Record info on the data sheet.

2. ㅁ. Transfer part of precipitate to Feed Tank.

3. Weigh cooling coil. Record info on run sheet.

4. $\square$ Prepare heel solution in beaker and sample. Record info on run sheet.

5. $\square$ Transfer the heel solution to the kettle. Flush with Rinse water \#3. Record the info on the run sheet.

6. $\square$ Start $\mathrm{CO}_{2}$ purge $15.82 \mathrm{scc}$.min on the feed tank and reactor.

7. $\square$ Start Argon purge $1.76 \mathrm{scc} / \mathrm{min}$ on the feed tank and reactor.

8. $\square$ Perform a leak check. flow in $=$ flow out

9. $\square$ Disconnect outlet flowmeter. Turn $\mathrm{CO}_{2}$ purge of reaction vessel to full scale to sweep out $\mathrm{O}_{2}$. Purge at this high rate for 30-40.min (can be heating vessel during this purge period).

10. $\square$ Insulate vessel and offgas lines.

11. $\square$ Turn on water to condenser. Setpoint $=40^{\circ} \mathrm{C}$.

12. $\square$ Turn on water to chilled condenser. Setpoint $=10^{\circ} \mathrm{C}$.

13. $\square$ Turn on precipitate feed agitator. Setpoint $=$ Turn on small $\mathrm{N}_{2}$ purge to feed tank.

14. $\square$ Turn on kettle agitator. Setpoint $=$

15. $\square$ Begin heating Pre-reaction heel to $90^{\circ} \mathrm{C}$. Turn on power, set setpoint to $90^{\circ} \mathrm{C}$, set load limit to 10 .

16. $\square$ When temp reaches $70^{\circ} \mathrm{C}$, set $\mathrm{CO}_{2}$ purge of reactor vessel back to $15.82 \mathrm{scc} / \mathrm{min}$ (it was at full range).

17. $\square$ Feed precipitate slurry at $17.58 \mathrm{ml} / \mathrm{min}$ while agitating slurry. Set load limit to 7 in room and 8 in room 112 when temp reached 90 degrees.

18. $\square$ Transfer remainder of precipitate to the feed tank. Record total amount of precipitate fed

on the run sheet. Flush carboy with rinse water \#1. Record info on the run sheet.

19. $\square$ Rinse the feed tank with Rinse water \#2.

20. $\square$ Pull a 5-mL Post-Feed Sample (use GLASS sample bottles). Record info on the run sheet. Clamp feed tube and turn off $\mathrm{N}_{2}$ to feed tank.

21. $\square$ Hold vessel at $90^{\circ} \mathrm{C}$ for 5 hours. Record hold start and stop time on run sheet. Drain the decanter organic so that the level never gets above the reflux leg.

22. $\square$ Pull additional $5 \mathrm{ml}$ samples every hour. Record information on the run sheet. Cool and refrigerate these samples promptly.

23. $\square$ Change temperature setpoint to $110^{\circ} \mathrm{C}$ to begin heating the kettle to boiling. Set load limit to 4 in lab 112 and 3.5 in lab 109 . Open reflux valve.

24. $\square$. Hold the liquid at boiling for 5 hours.

25. $\square$ Measure bơilup rate once an hour. (desired $2.0 \mathrm{~g} / \mathrm{min}$ ). Record data on data sheet. Check insulation.

26. $\square$ After 5 hour boil, cool reactor contents to less than $122^{\circ} \mathrm{F}\left(50^{\circ} \mathrm{C}\right)$ using a cooling coil. Keep GC running during cooldown.

27. $\square$ Add rinse water \#4 to the PHA product.

28. $\square$ Pull post-run samples of PHA, decanter organic and decanter aqueous.

29. $\square$ Transfer PHA into tared 1 Liter glass bottles. Record weights on runs sheet.

30. $\square$ Transfer condenser organic and aqueous out. Record total amounts obtained throughout the run on the data sheet.

31. $\square$ Turn off all instruments and gas flows.

32. $\square$ Place GC's in STANDBY mode per instructions.

33. $\square$ Re-weigh cooling coil. Put the coil in solvent to clean. Record the initial solvent mass, the mass of the solvent plus the organics, and the mass of the coil after cleaning on the run sheet. 


\title{
Appendix A - Experimental Procedures
}

\author{
PHA Heel Further Studies Experimental Procedure
}

1. $\square$ Turn on the GC and its computer and make sure that the computer and GC are matching set.

2. Install the calibration gas cylinder to the $G C$ and let the $G C$ run five times. If at the end of five runs, the GC reading is within 5\% of the gas composition in the cylinder, print the calibration check results and write down "pre-cal check and run number" in the printout. Otherwise, select "Calibration" "Level 1" "OK" to calibrate the GC five times. At the end of five runs the GC reading should be within $5 \%$ of the gas composition in the cylinder. If it is not, contact the engineer. Print the calibration check results and write down "pre-cal check and run number" in the printout.

3. Add required copper solution and formic acid and \#1 rinse water (from run sheet) to the kettle.

4. $\square$ Turn on kettle agitator. Setpoint $=$

5. $\square$ Transfer required precipitate (from run sheet) to the feed tank and purge the feed tank with nitrogen. Turn on precipitate feed agitator. Pump the precipitate in the line up to the kettle. Setpoint $=$

6. Turn on water to condenser $/$ decanter. Setpoint $=40^{\circ} \mathrm{C}$.

7. Turn on water to offgas condenser. Setpoint $=10^{\circ} \mathrm{C}$.

8. Turn on the purge gas with $17.6 \mathrm{scc} / \mathrm{min}$ of $\mathrm{CO}_{2}$ and $1.58 \mathrm{scc} / \mathrm{min}$ of argon to perform the leak check. The outlet flow should be $\approx 13.0 \mathrm{scc} / \mathrm{min}$. Write down the outlet flow in the log book. If it is not, tighten all connections until the system is leak tight.

9. $\square$ Start the GC for this run beginning with baseline reading for few minutes. The beginning GC reading should be approx. $10 \%$ argon and $90 \% \mathrm{CO}_{2}$. If it is not contact the engineer.

10. $\square$ Disconnect outlet flowmeter. Turn down flow rate of purge gas to $4.0 \mathrm{scc} / \mathrm{min}$ of $\mathrm{CO}_{2}$ and 0.44 scc/min of argon.

11. $\square$ Insulate vessel and offgas lines.

12. $\square$ Start heating the kettle to $90^{\circ} \mathrm{C}$ (Turn on power, setpoint at $90^{\circ} \mathrm{C}$, load limit at 10).

13. When kettle temperature reaches $70^{\circ} \mathrm{C}$, turn the load limit to 7 .

14. $\square$ When kettle temperature reaches $90^{\circ} \mathrm{C}$, start feeding precipitate slurry at $4.40 \mathrm{ml} / \mathrm{min}$ while agitating slurry. Adjust load limit to maintain the kettle at $90^{\circ} \mathrm{C}$. Record the information in the data sheet.

15. $\square$ When the feeding is complete, rinse the feed tank with rinse water \#2.

16. $\square$ When the feed tube is empty, clamp feed tube and turn off nitrogen to feed tank:

17. $\square$ Hold vessel at $90^{\circ} \mathrm{C}$ for 5 hours. Record hold start \& stop time on run sheet. Drain the decanter organic so that the level never gets above the reflux leg.

18. $\square$ When the five hour holding is complete, change temperature setpoint to $110^{\circ} \mathrm{C}$ to begin heating the kettle to boiling. Set load limit to Open reflux valve in the condenser/decanter.

19. $\square$ Hold the kettle at boiling (indicated by condenser/decanter flow) for 5 hours.

20. $\square$ Measure Boil-up rate once an hour (desired $0.5 \mathrm{~g} / \mathrm{min}$ ). Record data on data sheet. Check insulation.

21. $\square$ After 5 hour boiling, remove the insulation to cool the kettle to less than $122^{\circ} \mathrm{F}\left(50^{\circ} \mathrm{C}\right)$. Keep GC running during cooldown.

22. $\square$ Add Rinse Water \#3 to the PHA product.

23. $\square$ Pump PHA into tared 1 Liter glass bottle until the $200 \mathrm{ml}$ mark. Record weight on run sheet.

24. $\square$ Record the total amounts obtained on the data sheet.

25. $\square$ Turn off all instruments.

26. $\square$ Stop GC for this run.

27. $\square$ Install the calibration gas cylinder to the GC and run the post-cal check. If the check indicates OK, print a copy and write "post-cal check and run number" in the printout.

28. $\square$ Pull a sample from PHA for copper and formic acid analysis. 
Appendix B Raw Data

Raw Hydrogen Gas Chromatograph Data For Process Demonstration Experiments

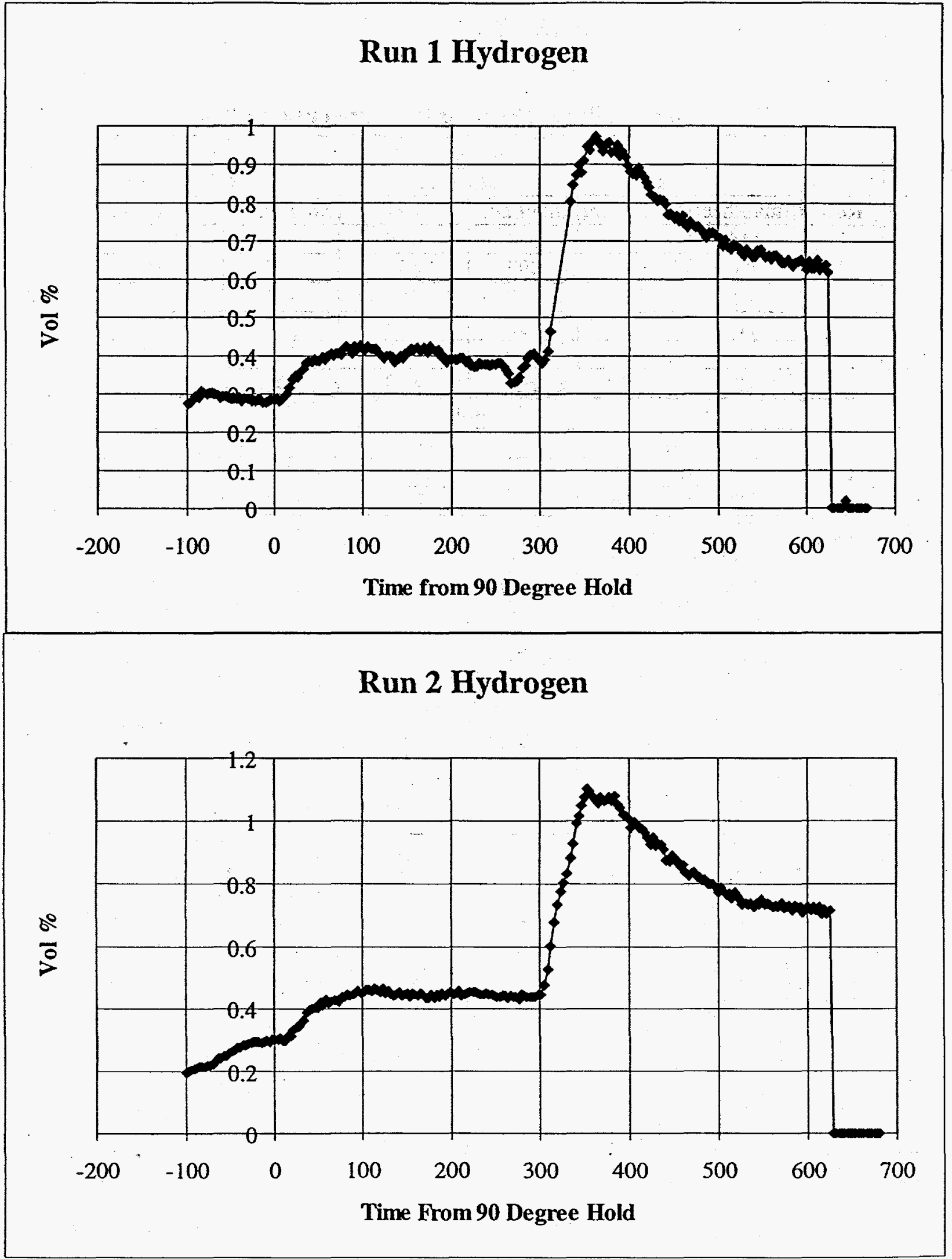

Appendix -3 


\section{Appendix B - Raw Data}

Organic ppm in Process Streams (measured using HPLC)

\begin{tabular}{|c|c|c|c|c|c|c|}
\hline \multicolumn{7}{|c|}{ Aniline } \\
\hline & \multicolumn{2}{|c|}{ Organic } & \multicolumn{2}{|c|}{ Aqueous } & \multicolumn{2}{|c|}{ Product } \\
\hline Run & Small heel & Large heel & Small heel & Large heel & Small heel & Large heel \\
\hline 1 & $\because 144$ & 219 & 644 & 678 & 166 & 127 \\
\hline 2 & 84 & 136 & 497 & 636 & 130 & 180 \\
\hline 3 & 10 & 10 & 378 & 608 & 125 & 189 \\
\hline 4 & 10 & 10 & 533 & 825 & 137 & 194 \\
\hline 5 & 10 & 10 & 759 & 526 & 143 & 199 \\
\hline 6 & 10 & 10 & 752 & 490 & 179 & 240 \\
\hline \multicolumn{7}{|c|}{ Phenol } \\
\hline & \multicolumn{2}{|c|}{ Organic } & \multicolumn{2}{|c|}{ Aqueous } & \multicolumn{2}{|c|}{ Product } \\
\hline Run & Small heel & Large heel & Small heel & Large heel & Small heel & Large heel \\
\hline 1 & 3782 & 4586 & 2010 & 2236 & 1107 & 1121 \\
\hline 2 & 5124 & 5505 & 2310 & 2312 & 1135 & .1129 \\
\hline 3 & 5337 & 5235 & 2264 & 2186 & 1127 & 1076 \\
\hline 4 & 8050 & 6577 & 2369 & 2320 & 1213 & 1097 \\
\hline 5 & 6015 & 6969 & 2287 & 2344 & 1159 & 1115 \\
\hline 6 & 5727 & 8485 & 2323 & 2461 & 1250 & 1149 \\
\hline \multicolumn{7}{|c|}{ Diphenylamine } \\
\hline & \multicolumn{2}{|c|}{ Organic } & \multicolumn{2}{|c|}{ Aqueous } & \multicolumn{2}{|c|}{ Product } \\
\hline Run & Small heel & Large heel & Small heel & Large heel & Small heel & \begin{tabular}{|l} 
Large heel \\
\end{tabular} \\
\hline 1 & 1379 & 905 & 8 & 12 & 42 & 34 \\
\hline 2 & 3180 & 2751 & 14 & 9 & 36 & $3 I$ \\
\hline 3 & 3574 & 2503 & 10 & 0 & 40 & 32 \\
\hline 4 & 5309 & 3246 & 0 & 0 & 55 & 26 \\
\hline 5 & 4173 & 4347 & 7 & 6 & 48 & 27 \\
\hline 6 & 4484 & 4450 & 5 & 9 & 44 & 31 \\
\hline \multicolumn{7}{|c|}{ BIP } \\
\hline & \multicolumn{2}{|c|}{ Organic } & \multicolumn{2}{|c|}{ Aqueous } & \multicolumn{2}{|c|}{ Product } \\
\hline Run & Small heel & Large heel & Small heel & Large heel & Small heel & Large heel \\
\hline 1 & \begin{tabular}{|l|}
9517 \\
\end{tabular} & \begin{tabular}{|l|}
8879 \\
\end{tabular} & \begin{tabular}{|l|}
0 \\
\end{tabular} & 0 & 0 & 13 \\
\hline 2 & 55460 & 55302 & $\underline{0}$ & 0 & 8 & 12 \\
\hline 3 & 85033 & 78084 & 0 & 8 & 13 & 20 \\
\hline 4 & 132818 & 119374 & 10 & 10 & 18 & 15 \\
\hline 5 & 119155 & 140024 & 6 & 5 & 34 & 14 \\
\hline 6 & 124923 & 168307 & 7 & 7 & 25 & 17 \\
\hline
\end{tabular}


Appendix B Raw Data

\section{Run 3 Hydrogen}

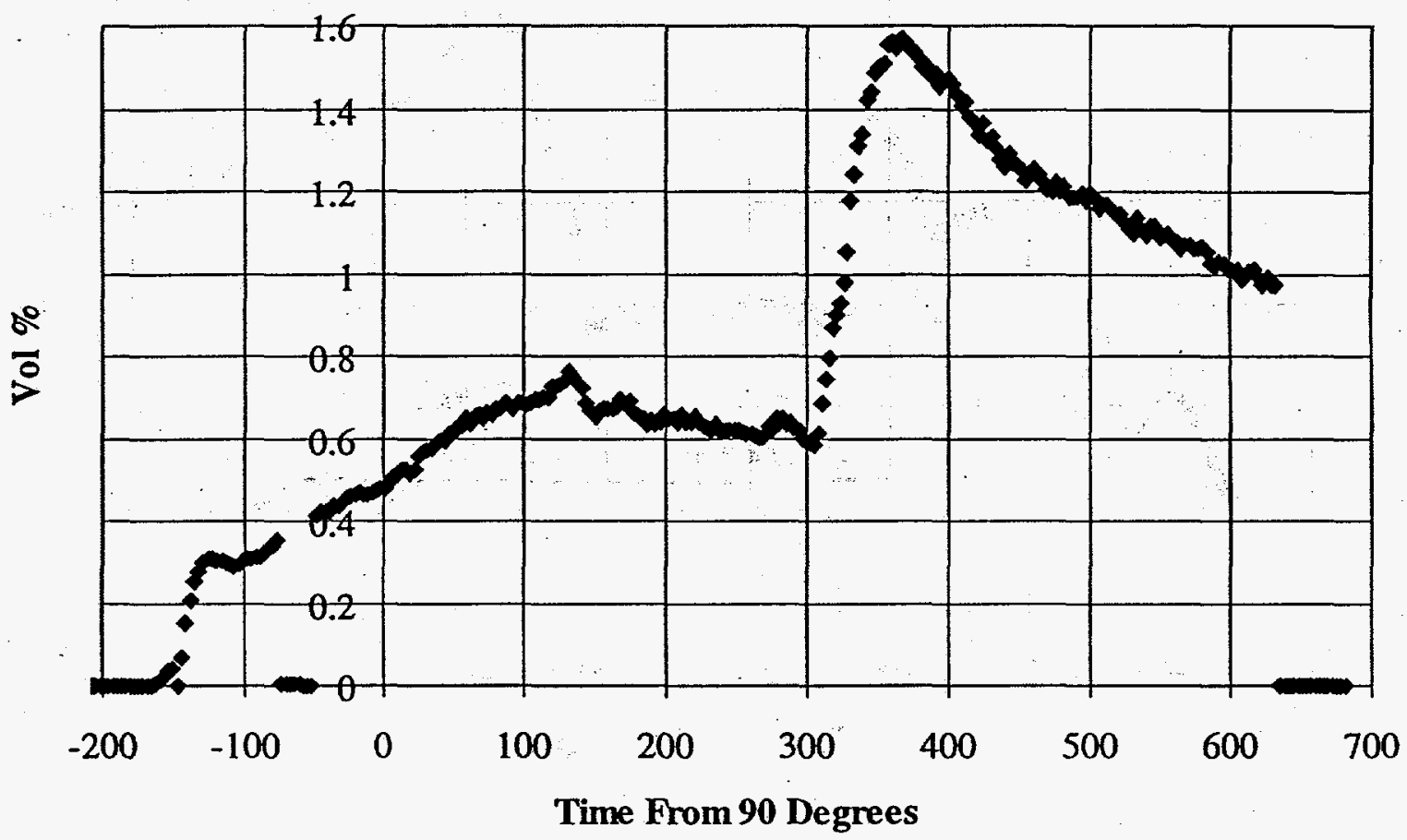

\section{Run 4 Hydrogen}

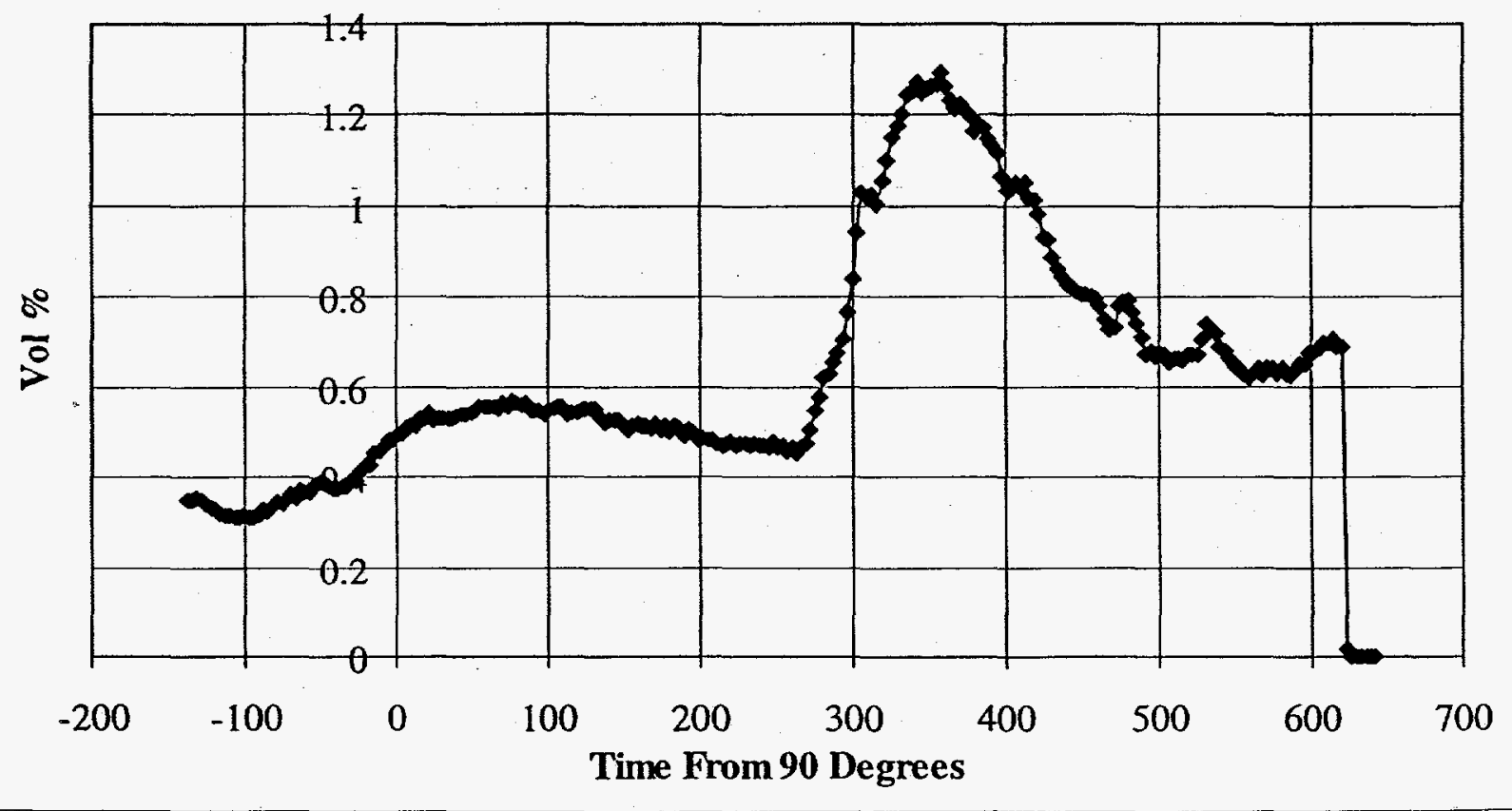


Appendix B Raw Data
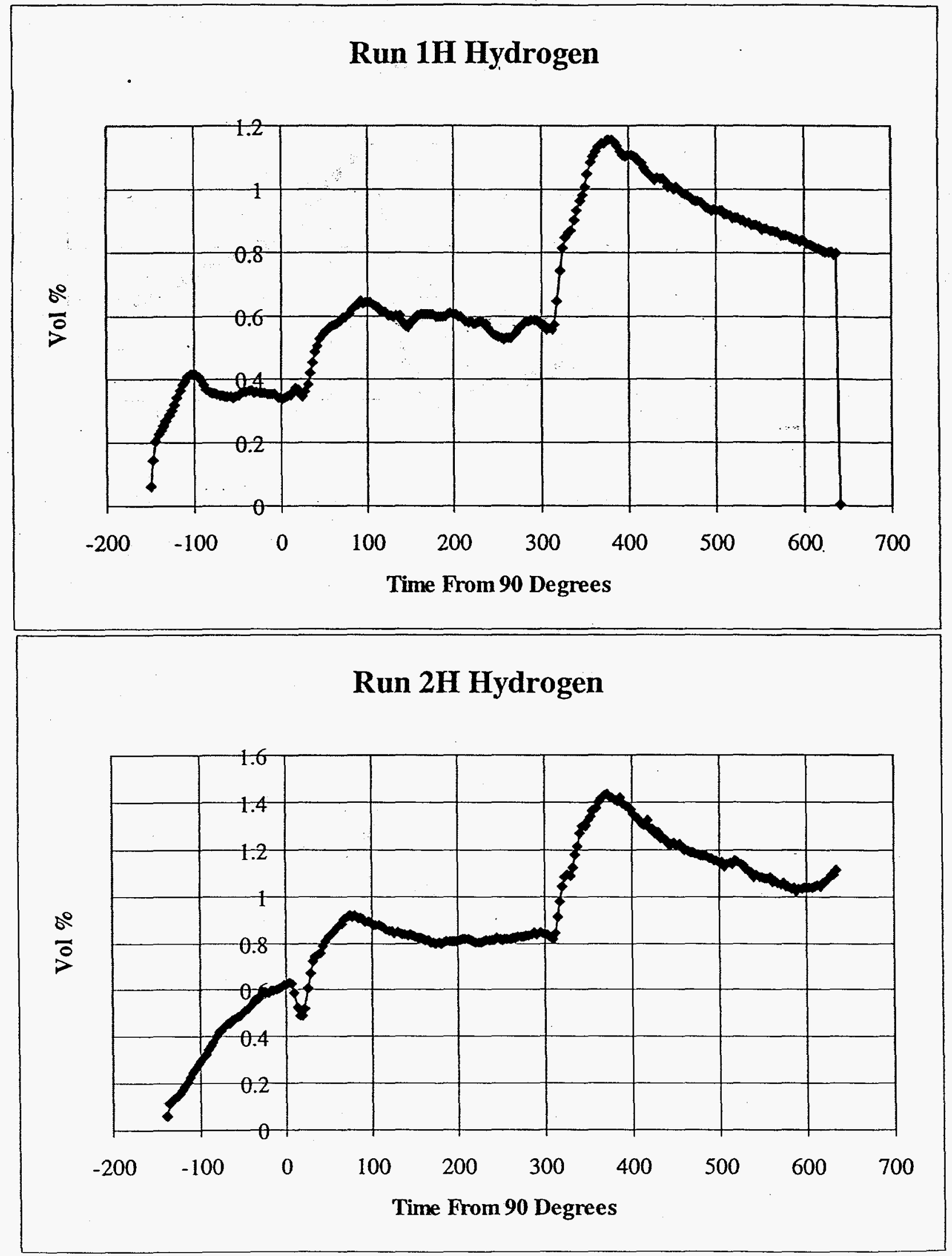

Appendix -6 
Appendix B Raw Data

\section{Run 3H Hydrogen}

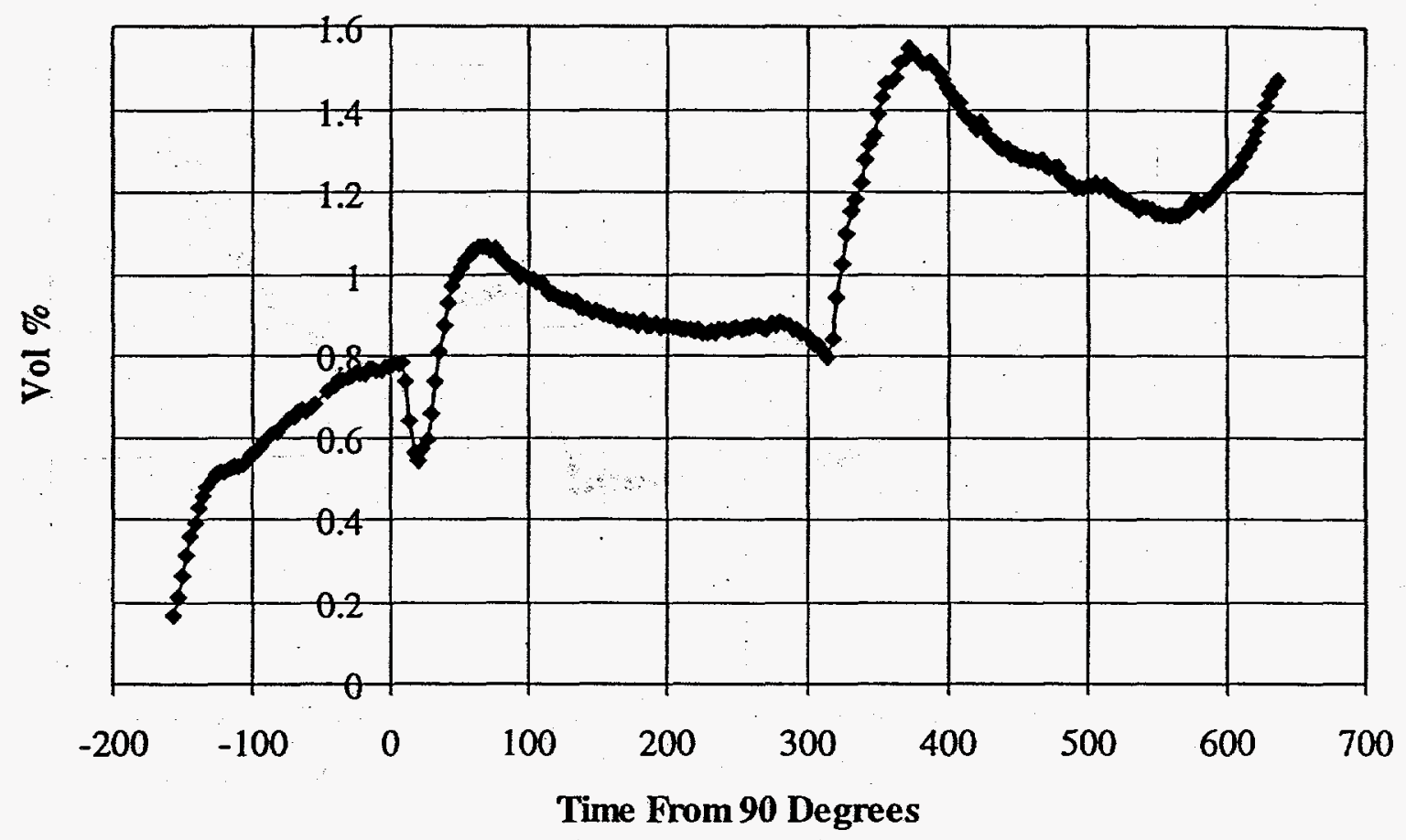

\section{Run 4H Hydrogen}

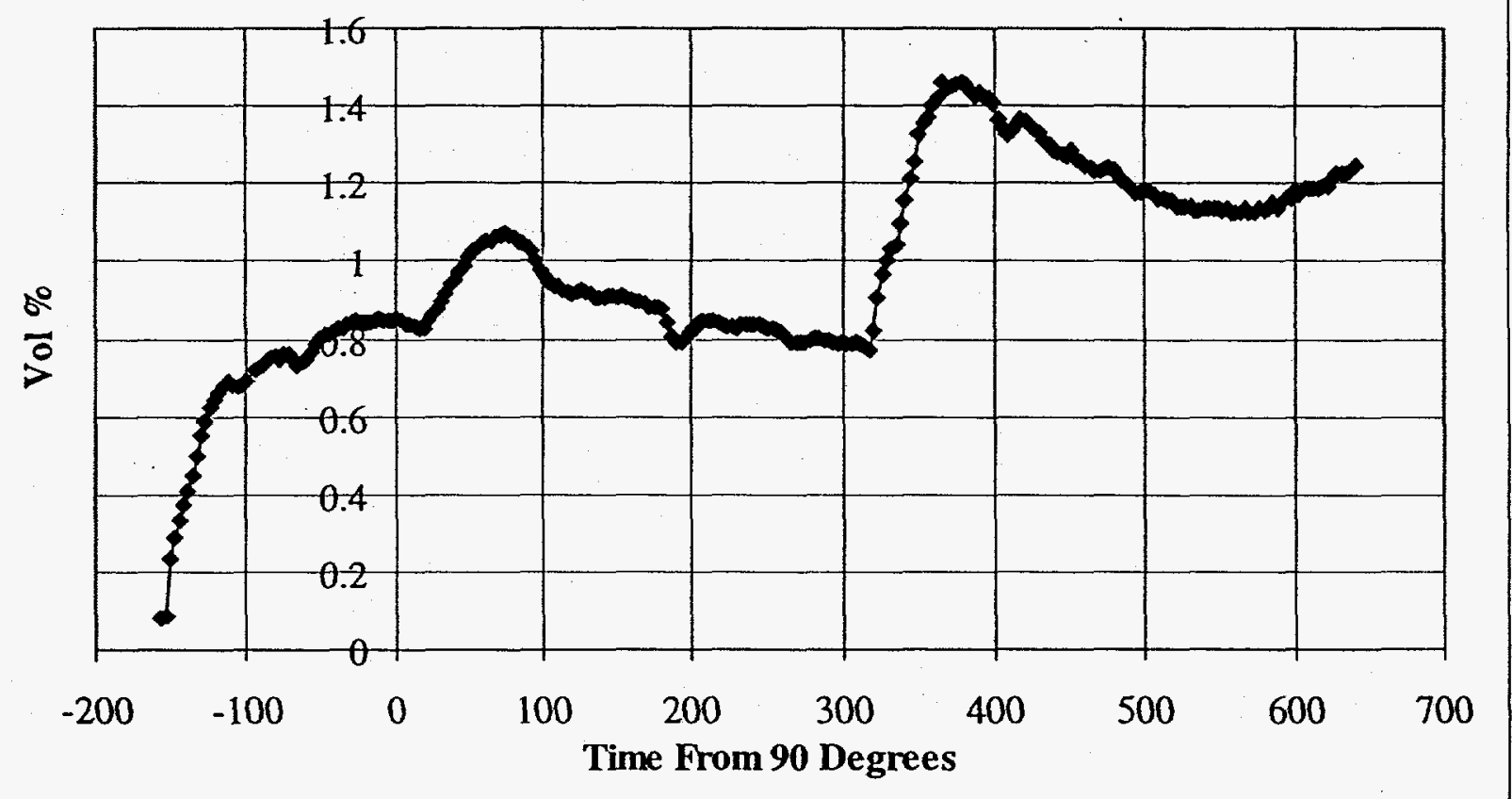


Appendix B Raw Data

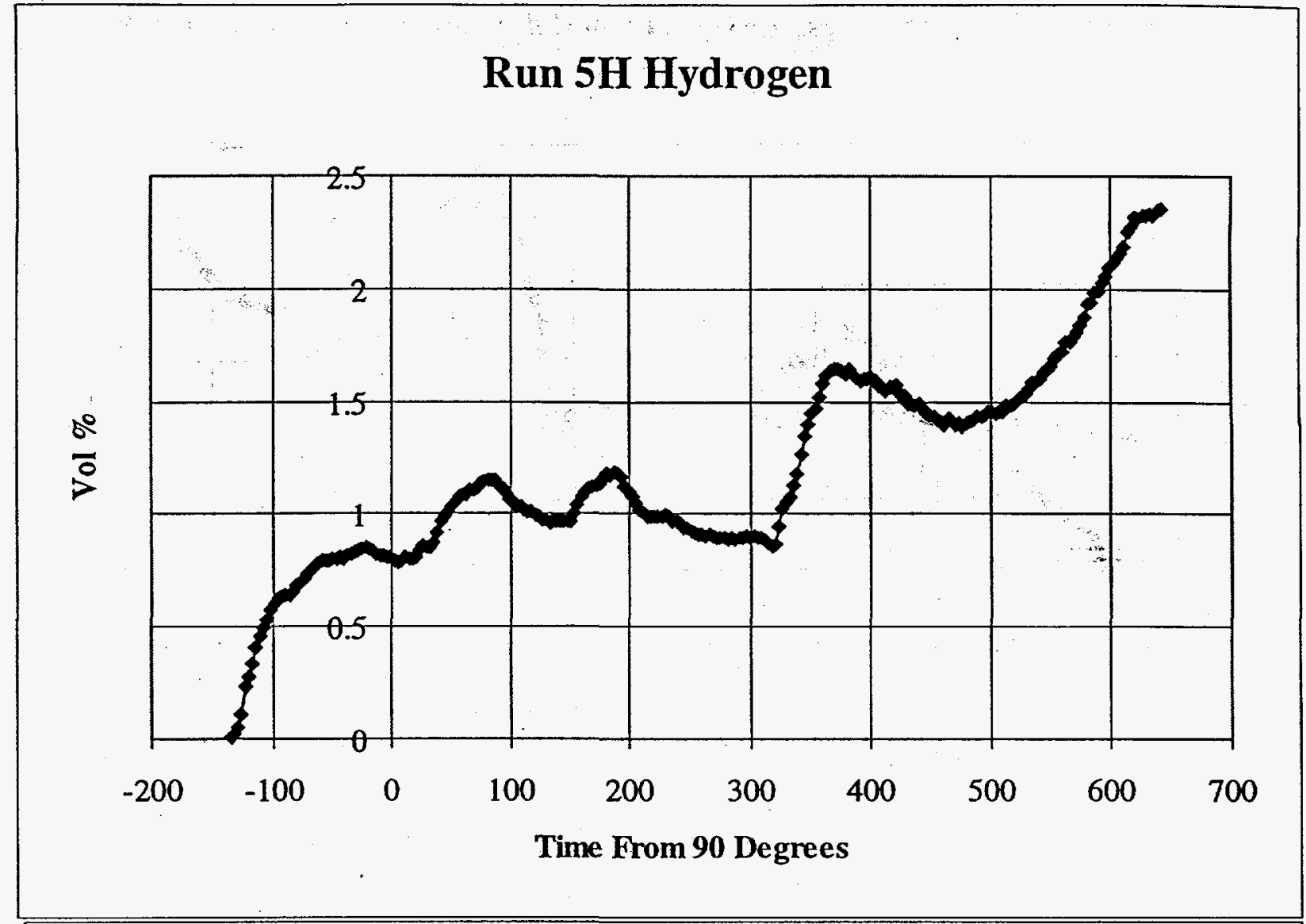

\section{Run 6H Hydrogen}

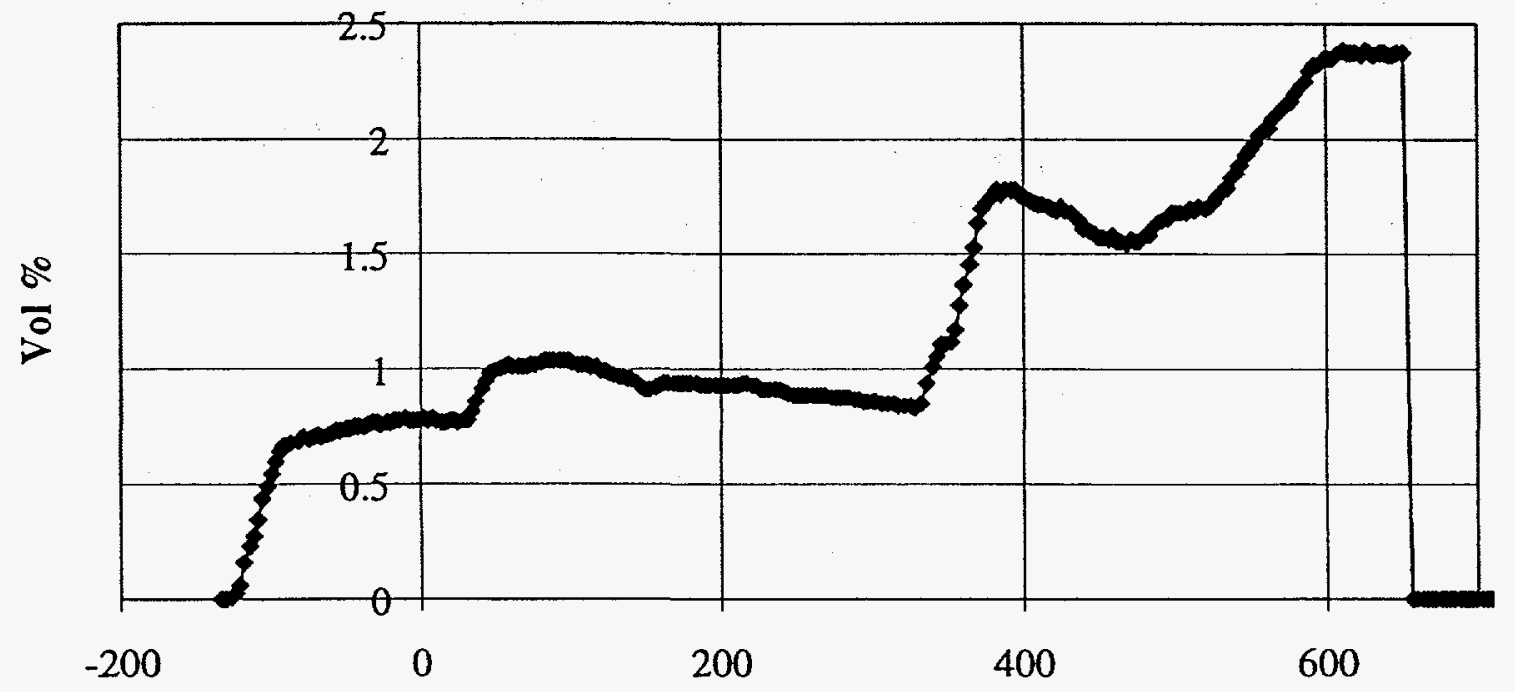

Time From 90 Dégrees 


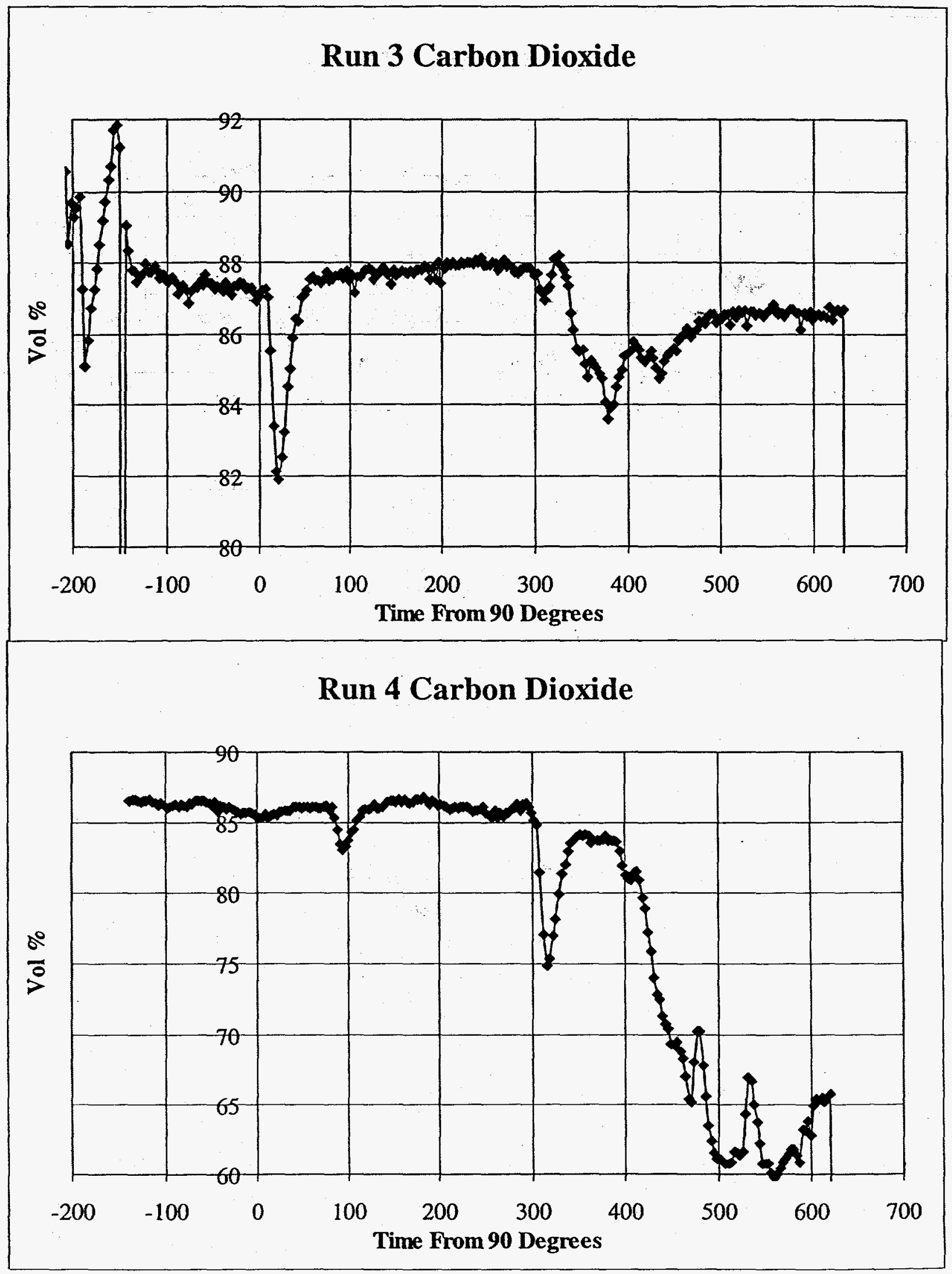




\section{Run 1H Carbon Dioxide}

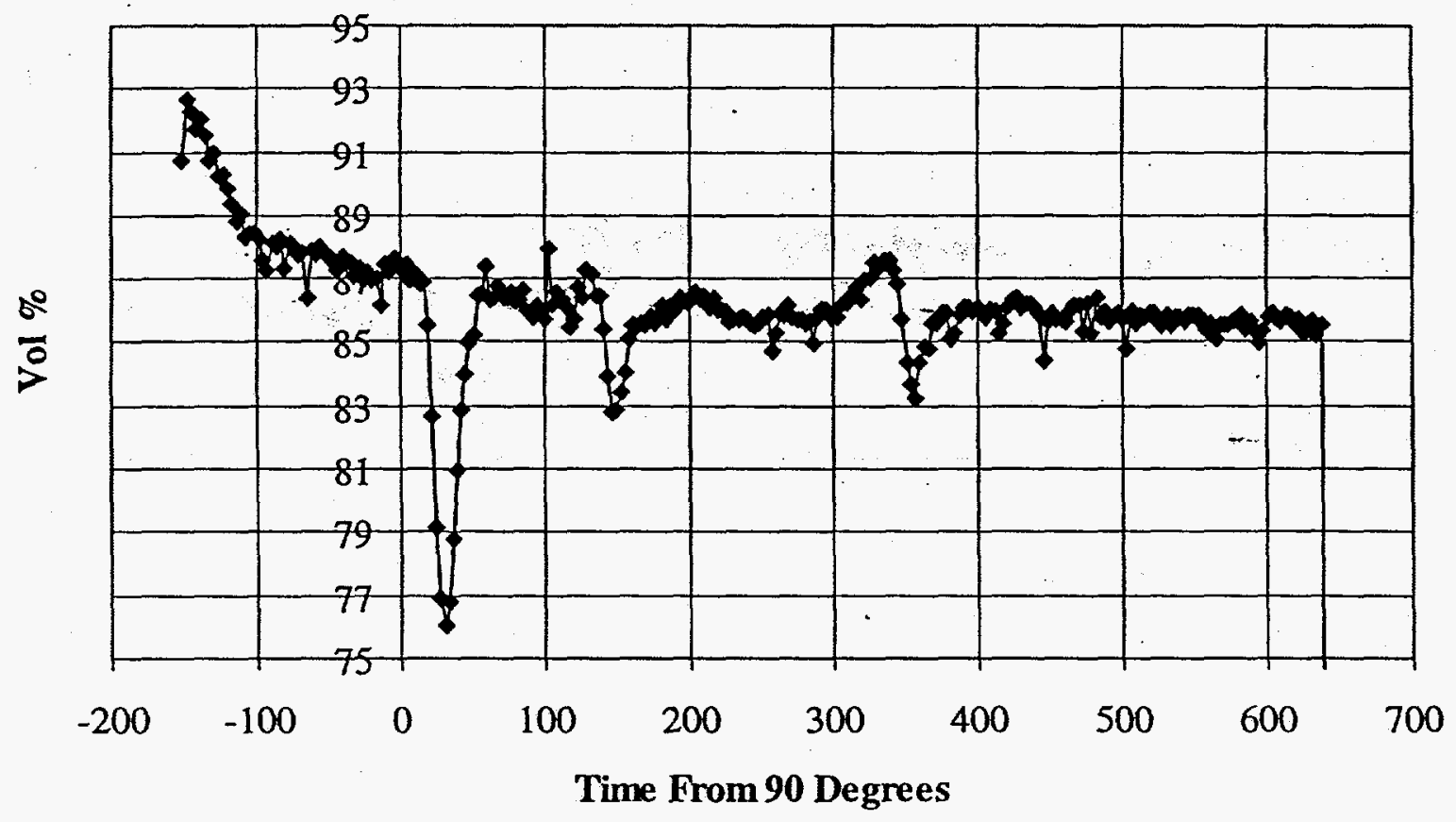

Run 2H Carbon Dioxide

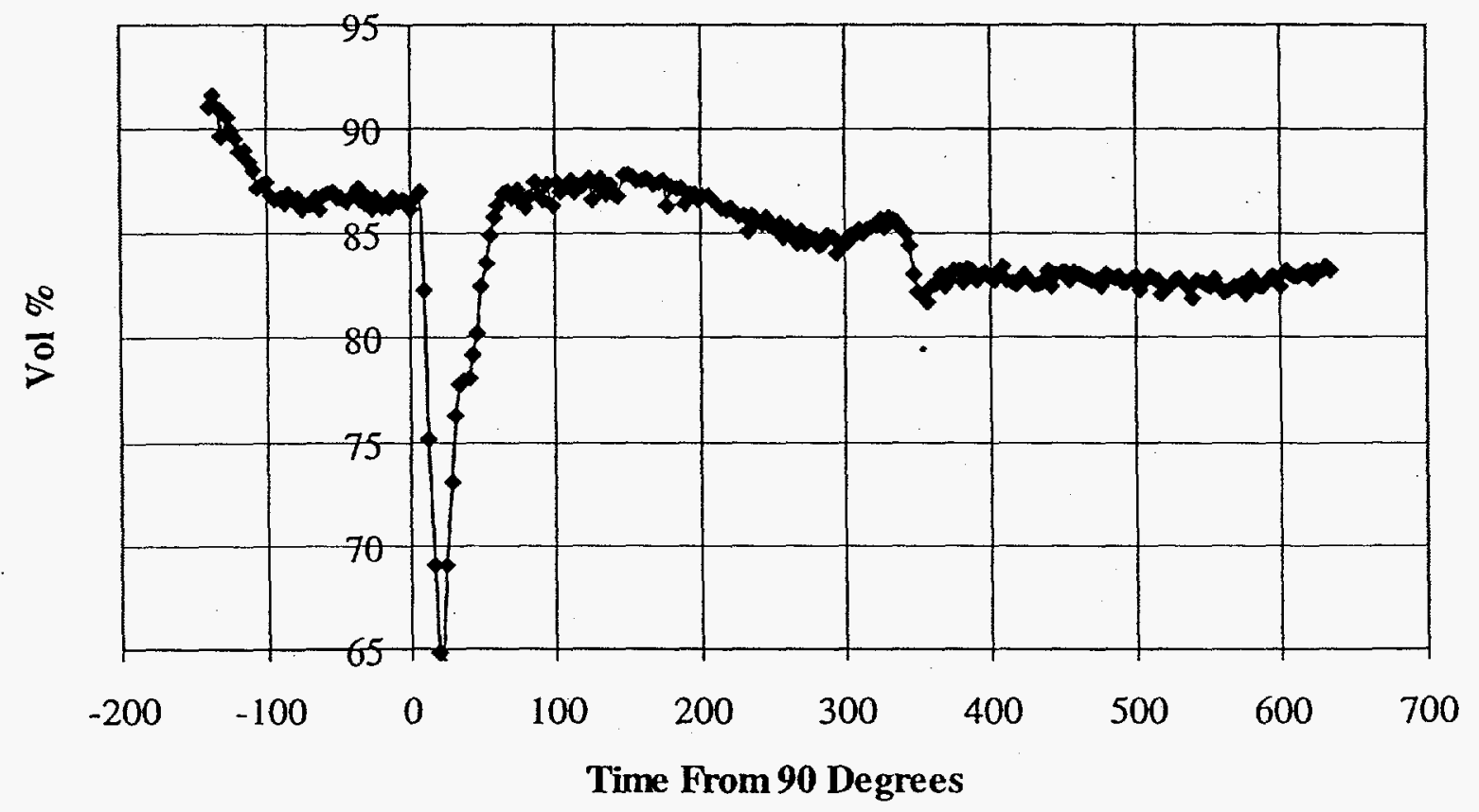


Appendix B Raw Data

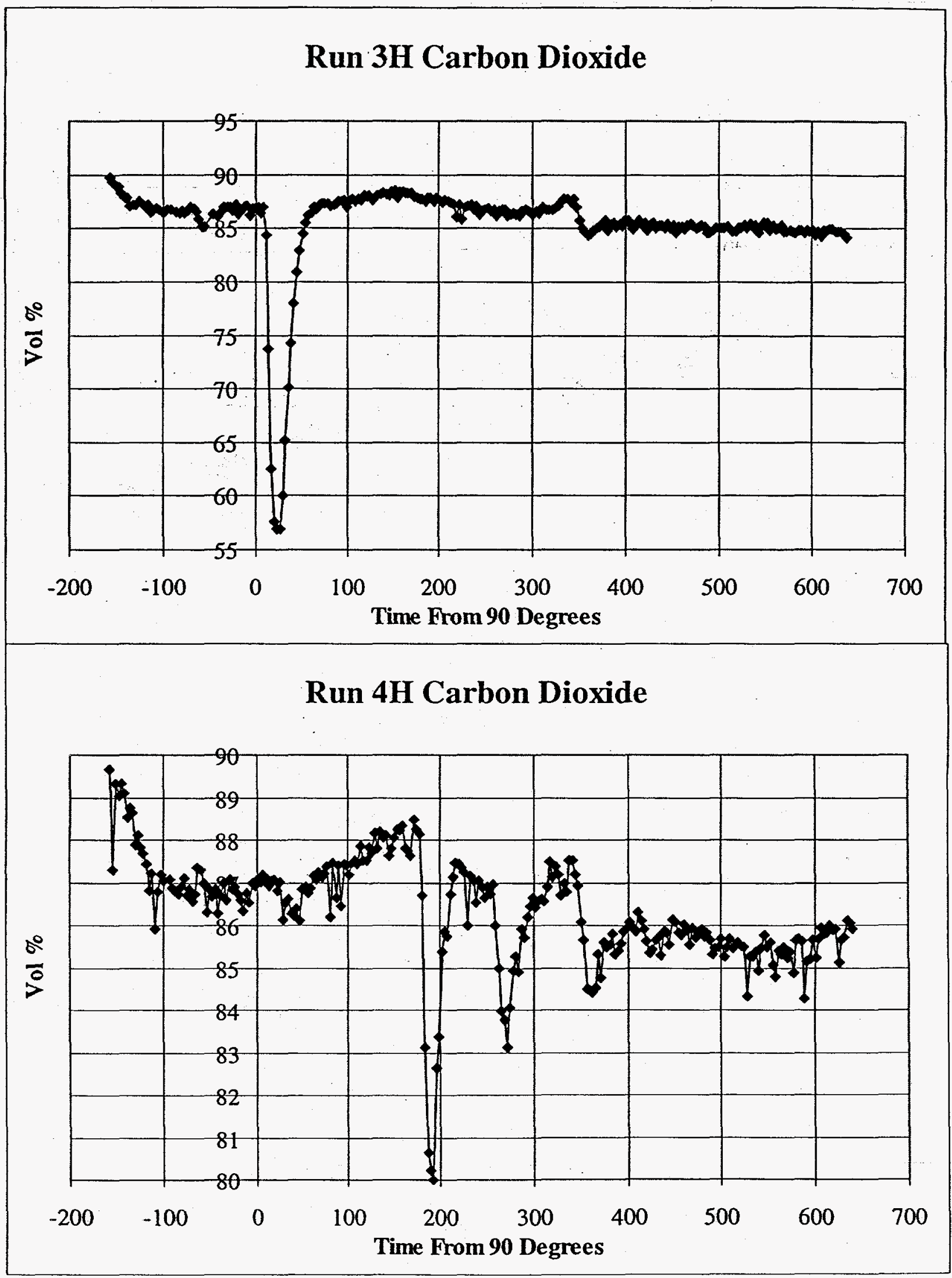




\section{Run 5H Carbon Dioxide}

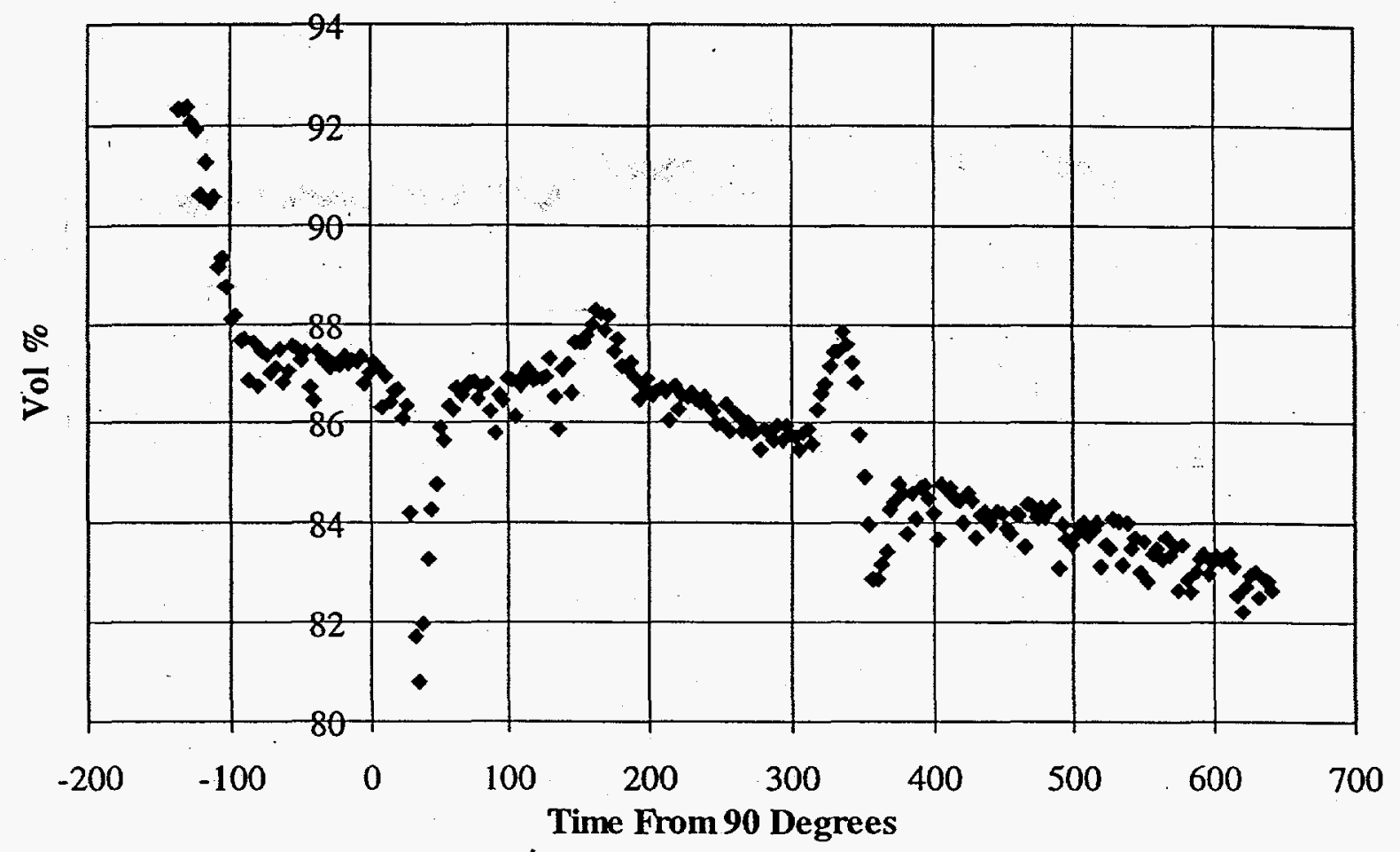

Run 6H Carbon Dioxide

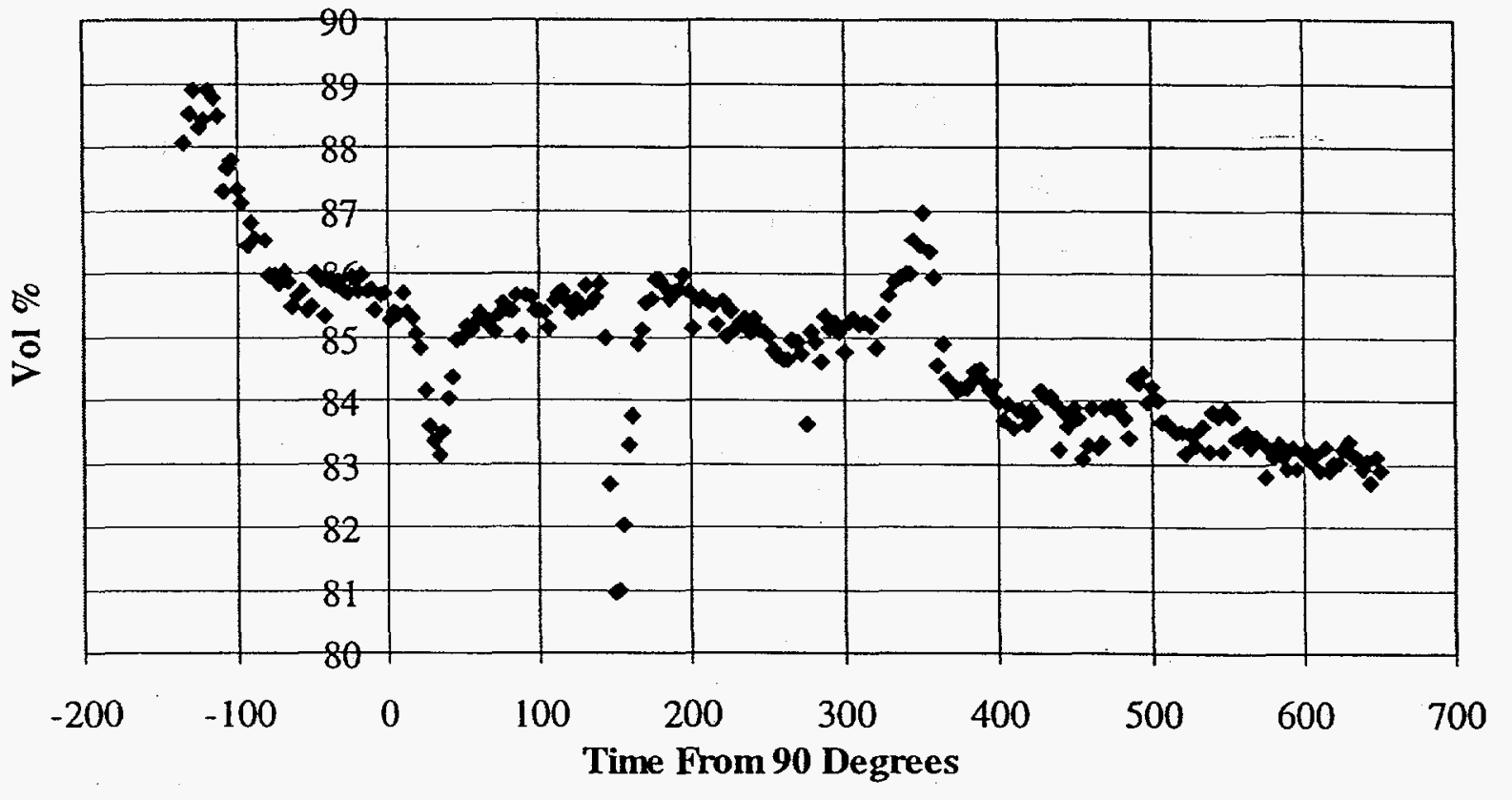


Appendix B Raw Data

Raw Argon Gas Chromatograph Data for the Process Demonstration Experiments

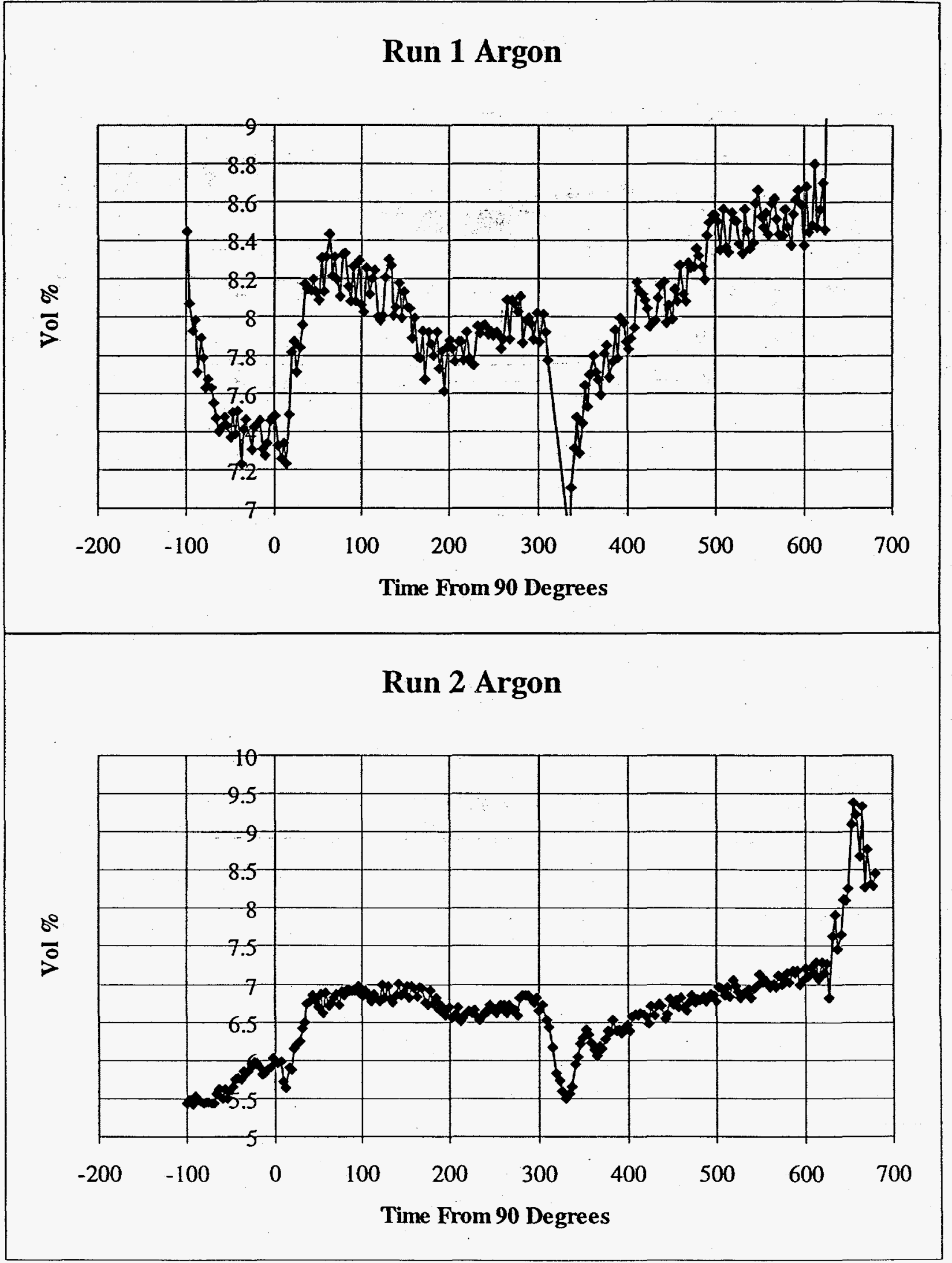

Appendix -15 
Appendix B Raw Data

Run 3 Argon

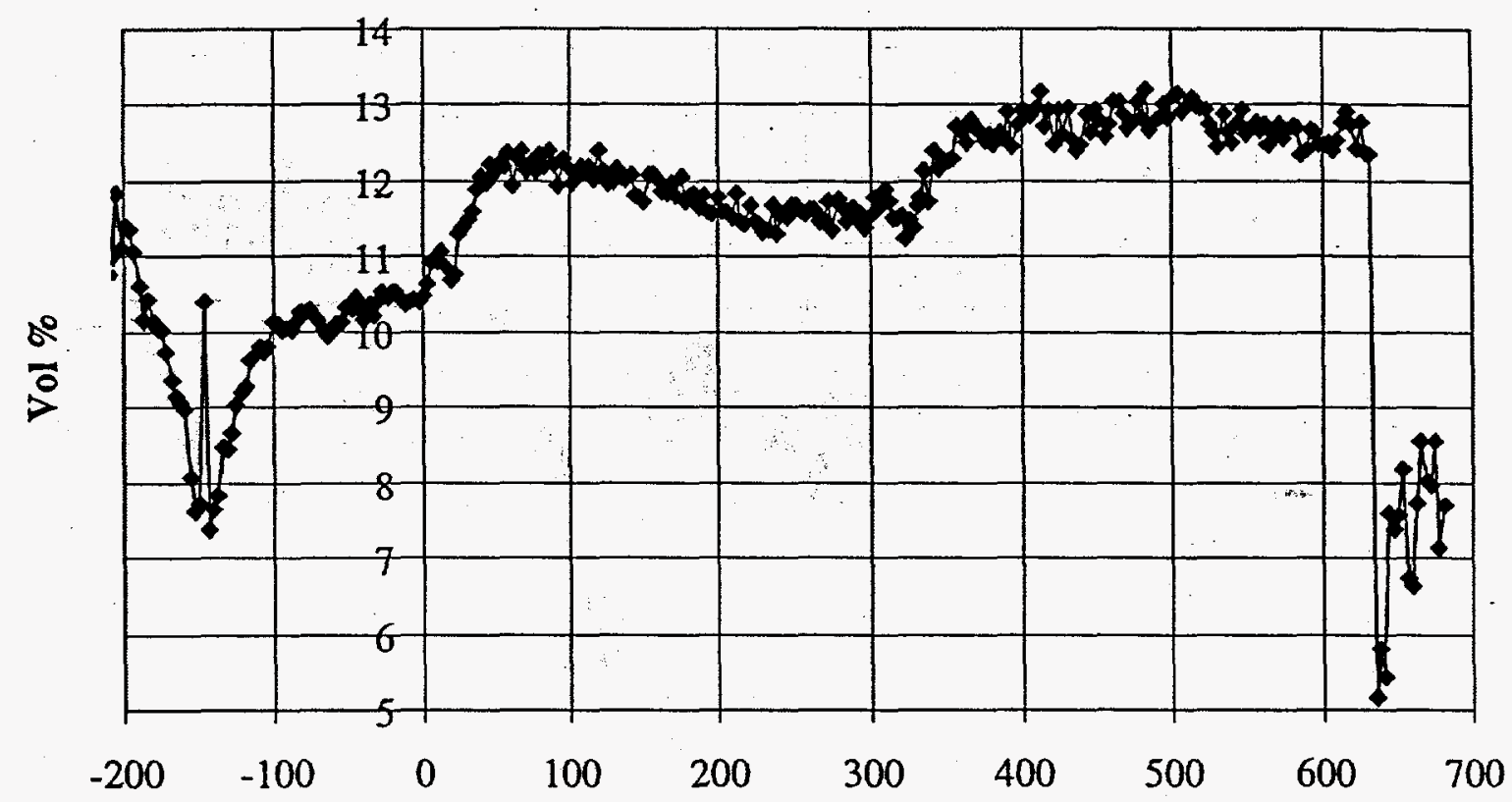

Time From 90 Degrees

Run 4 Argon

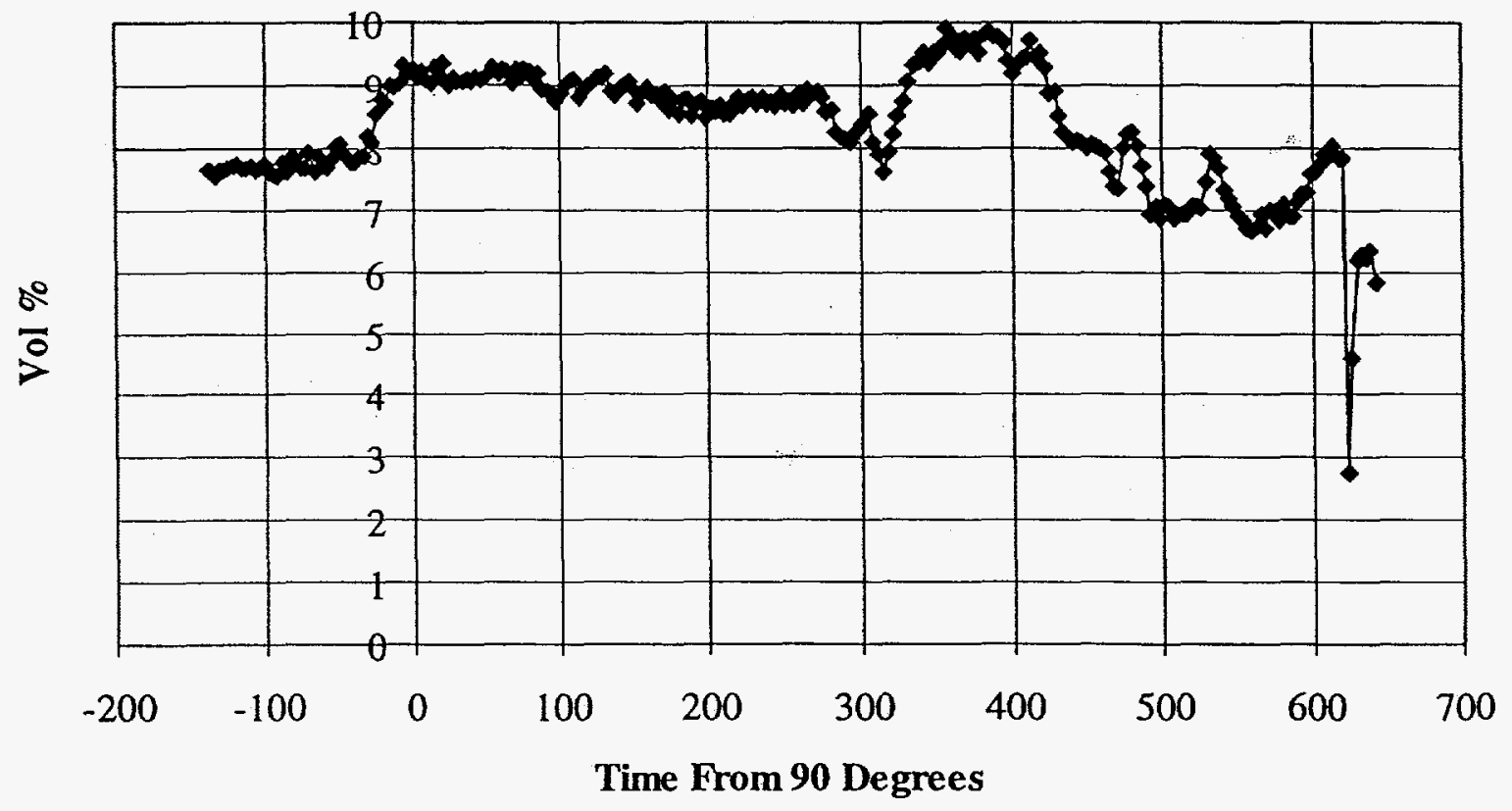

Appendix -16 
Run 5 Argon

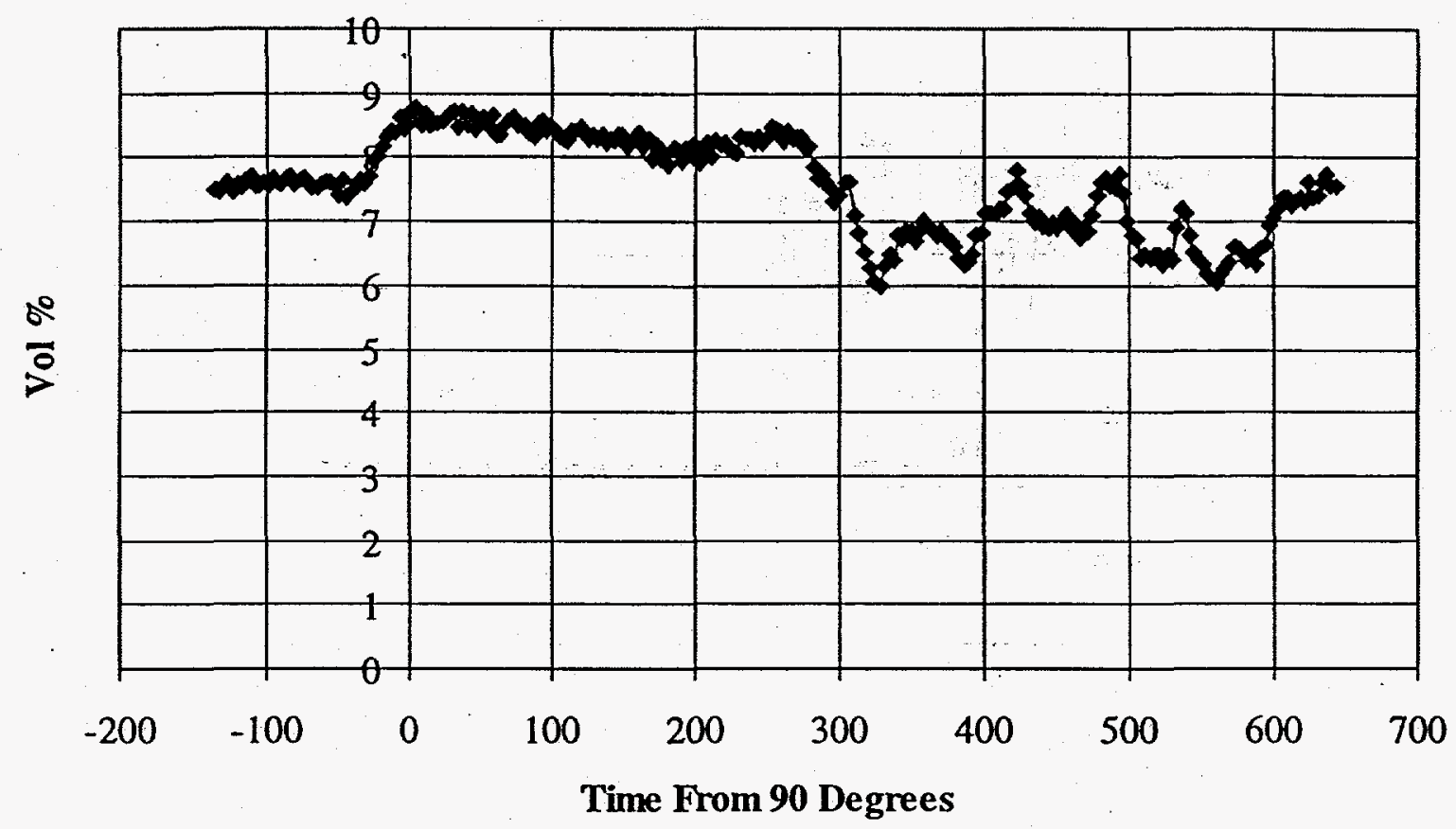

\section{Run 6 Argon}

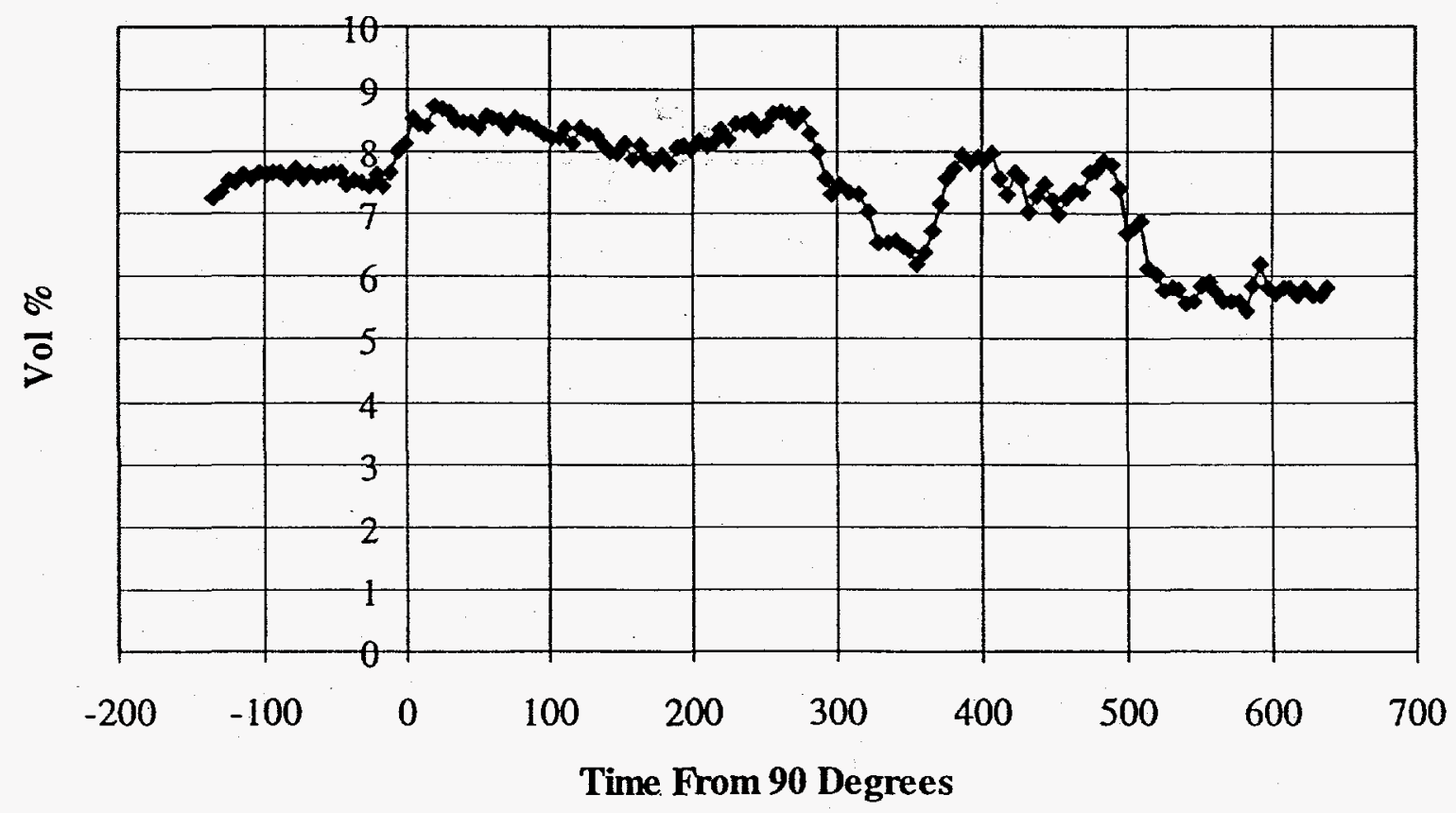


Appendix B Raw Data

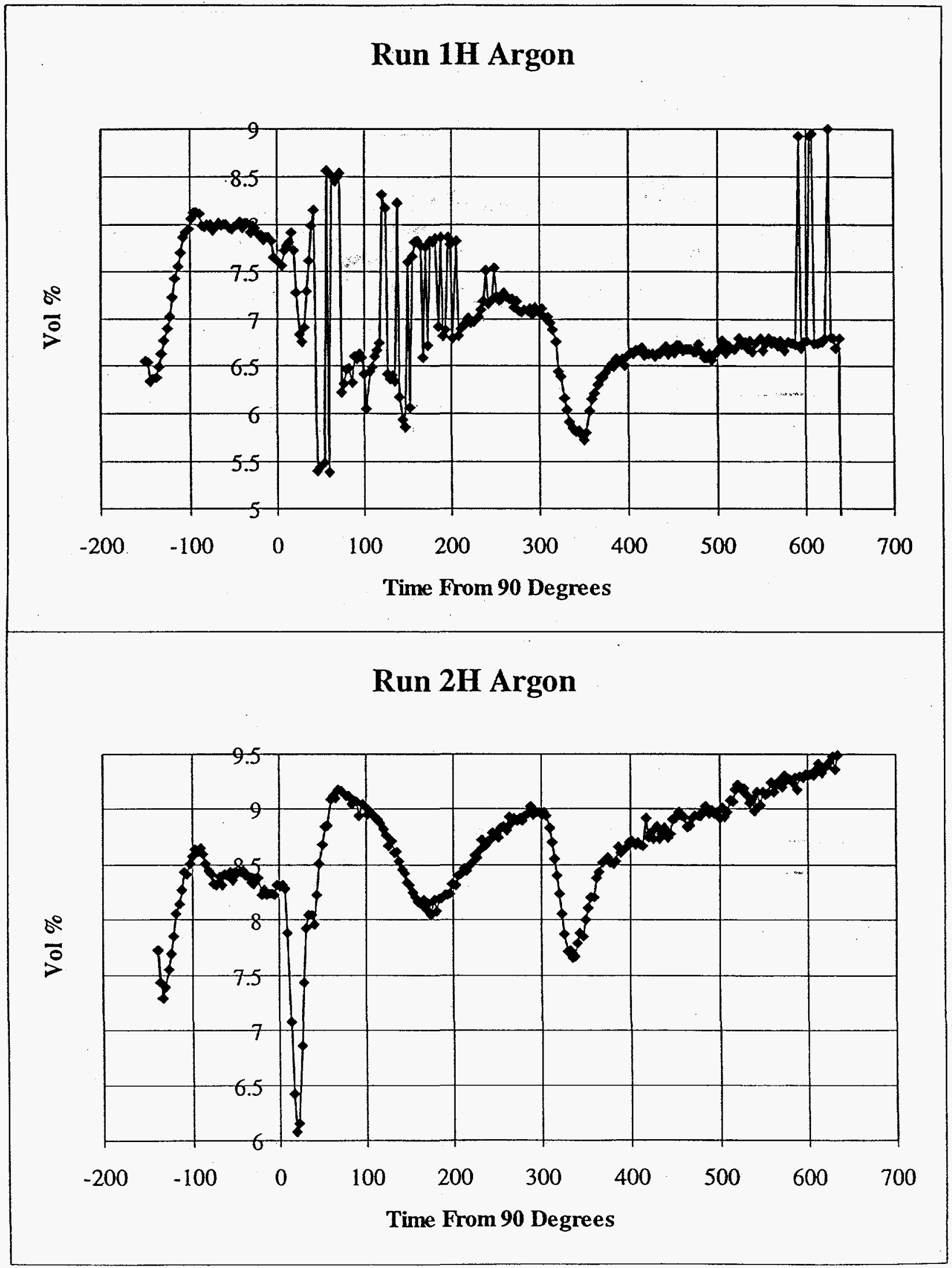

Appendix -18 
Appendix B Raw Data

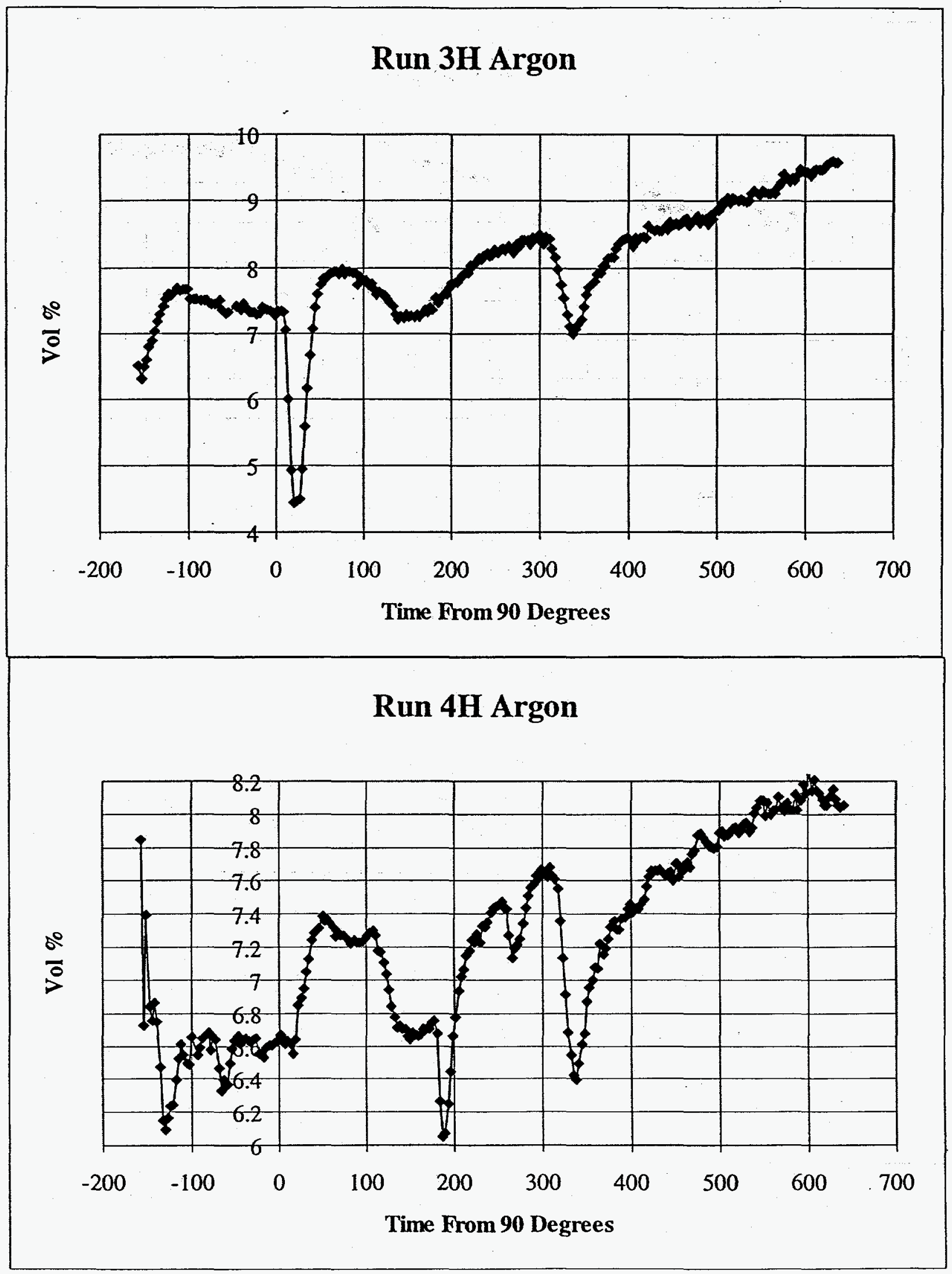

Appendix -19 


\section{Appendix B Raw Data}

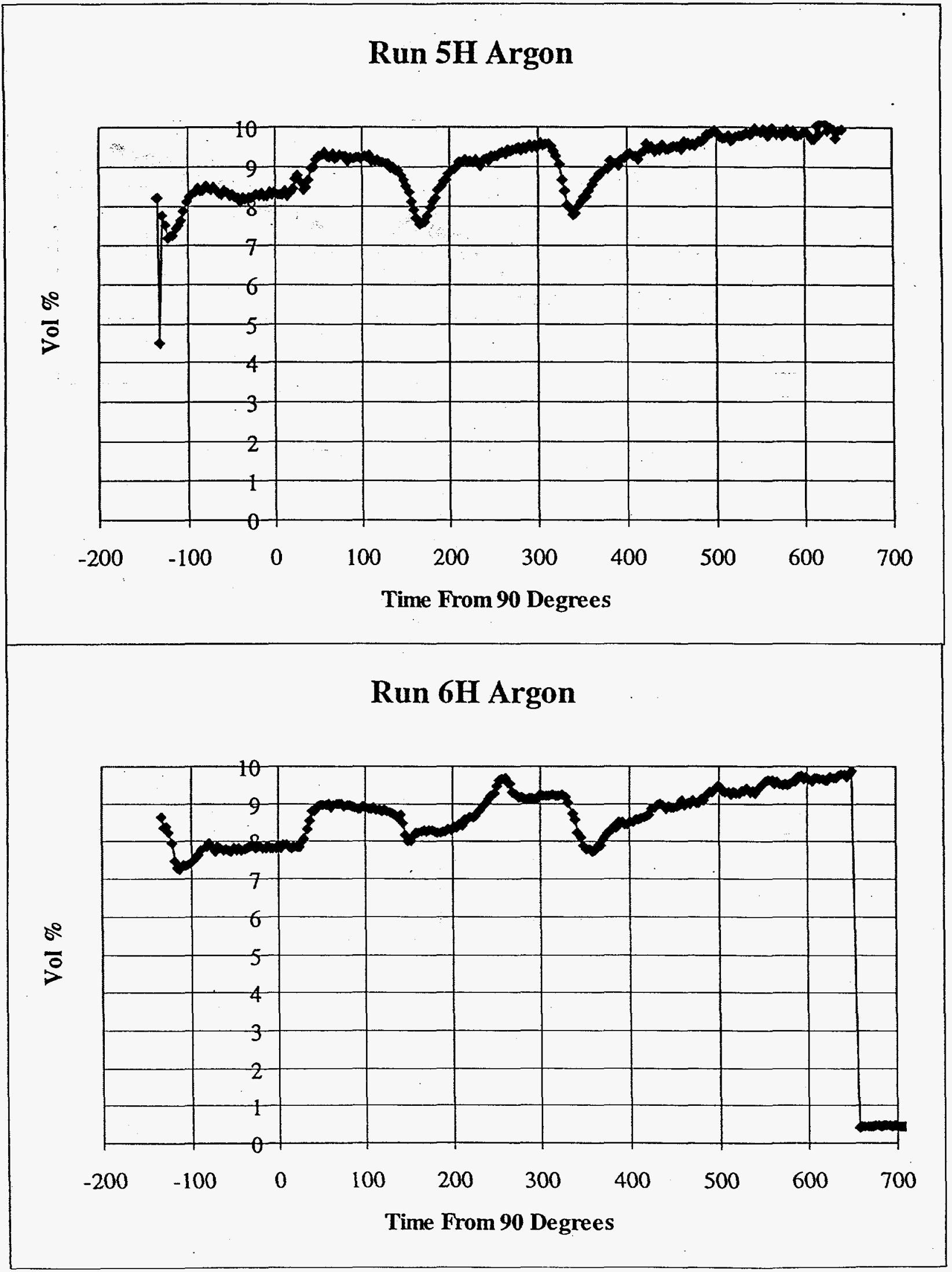

Appendix -20 


\section{Appendix B - Raw Data}

\section{Batching Calculation for the Process Demonstration Experiments}

Feed

TPB-, wt\%

Base Equiv to $\mathrm{pH} 5.5, \mathrm{M}$

Ins. Solids, wt\%

SpG, estimated

Nitrite, mg/L

\begin{tabular}{|c|}
\hline $7.98 \mathrm{wt} \%$ \\
\hline 0.0131 \\
\hline $10.21 \%$ \\
\hline 1.0184 \\
\hline 410 \\
\hline
\end{tabular}

$$
0.250 \mathrm{M}
$$

\section{Copper Solution}

wt\% $\mathrm{Cu}$

\begin{tabular}{|l|}
\hline 1470 \\
\hline $1.47 \%$ \\
\hline
\end{tabular}

Formic Acid

Formic, wt\%

Formula Wt. density 1.2015

I.

Enter Target Parameters:

Feed/Heel Ratio

Batch Size, $g$

Heel Size, $g$

$\%$ Recycle

Final Acidity, M

Target Acidity

Final Total Cu, ppm

Heel Sample Size, g.

Estimated Rinse Water,g

Projected Organic, $\mathrm{g}$

Projected PHA, $g$

PHA Guess

Acid Reqm't

For TPB-, g-mol

For Base Equivs, g-mol

For Acidity Target, g-mol

Nitrite,g-mol

Net Acid Req'd, g-mol

Acid in heel, $\mathrm{g}$-mol

acid to add, $\mathrm{g}$-mol

Formic Acid Required, g

Copper Requirement

Heel + Feed - Benzene
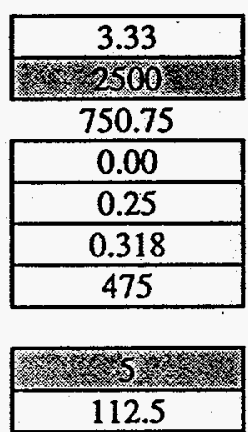

6.25E-01

3.21E-02

$1.73 \mathrm{E}+00$

\section{.25}

0.1825

0675

Formic, $\mathbf{g}$

Copper Soln, $g$

PHA, $g$

Copper in $1.47 \%$ Sol'n, $\mathrm{g}$

3168.00

80.82

83.42

3332.24

1.226

0.357

1.583

Total Copper in PHA, $g$

Summary

Heel Solution, $g$

$1.47 \mathrm{wt} \% \mathrm{Cu}$ Solution, $\mathrm{g}$

$90 \mathrm{wt} \%$ Formic, $\mathrm{g}$

Aq. Prod. Recycle, $g$

Water, $g$

Amount

750.75

83.42

80.82

0.00

112.50
195.25

3332.24

3330.91

2644.61

$1.06 \mathrm{E}+00$

2.01E-02

$1.86 \mathrm{E}-01$

$1.55 \mathrm{E}+00$

80.82

PHA delta

$-1.33$

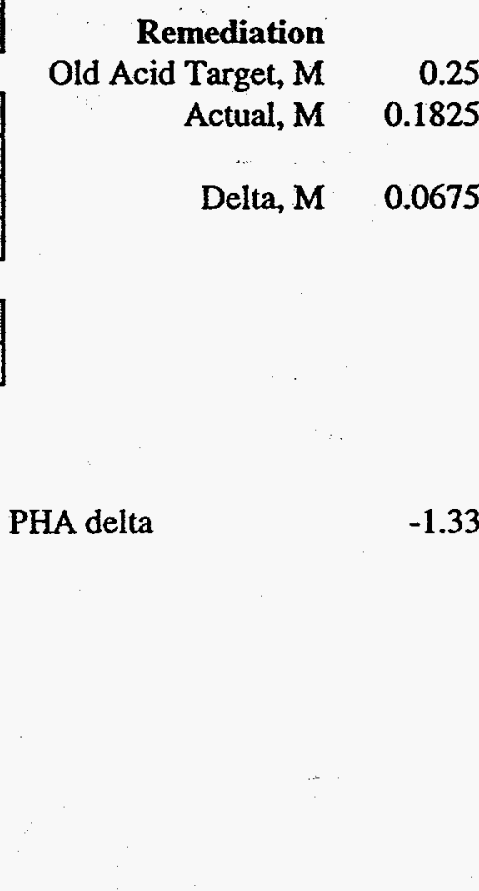

final acid, $\mathrm{M} 0.321$
Heel mass, $\mathrm{g}$

Heel Volume, ml

Heel Acid, $M$

Heel Copper, ppm
Heel

\begin{tabular}{rc} 
ppm copper & 475 \\
\hline Acidity, $M$ & 0.25 \\
density & 1.01
\end{tabular}




\section{Appendix C $\quad$ Raw Data}

Batching Calculation for the Scoping Experiments and Tests 1-7

Feed

TPB-, wt\%

Base Equiv to $\mathrm{pH} 5.5, \mathrm{M}$

Ins. Solids, wt\%

SpG, estimated

Nitrite, $\mathrm{mg} / \mathrm{L}$

\begin{tabular}{|c|}
\hline $7.98 \mathrm{wt} \%$ \\
\hline 0.0131 \\
\hline $10.21 \%$ \\
\hline 1.0184 \\
\hline 410 \\
\hline
\end{tabular}

$0.250 \mathrm{M}$

\section{Copper Solution}

$\mathrm{wt} \% \mathrm{Cu}$

\begin{tabular}{|c|}
\hline 1470 \\
\hline $1.47 \%$ \\
\hline
\end{tabular}

Formic Acid

Formic, wt\% $88.22 \%$

Formula Wt. 46.03

density 1.2015 density

ppm copper

cidity, M

\begin{tabular}{|c|}
\hline 47.5 \\
\hline 0.25 \\
1.01
\end{tabular}

Enter Target Parameters:

Feed/Heel Ratio

Batch Size, $\mathbf{g}$

Heel Size, $\mathrm{g}$

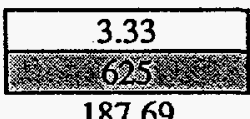

Remediation

187.69

Old Acid Target, $\quad 0.25$

$\%$ Recycle

Final Acidity, $M$

Target Acidity

Final Total Cu, ppm

\begin{tabular}{|c|}
\hline 0.00 \\
\hline 0.25 \\
\hline 0.318 \\
\hline 475 \\
\hline
\end{tabular}

Actual, M 0.1825

Delta, M 0.0675

Heel Sample Size, g.

Estimated Rinse Water,g

Projected Organic, g

Projected PHA, g

PHA Guess

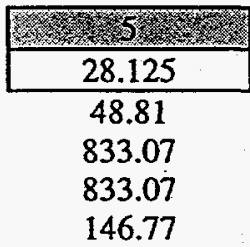

PHA delta

0.00

Acid Reqm't

For TPB-, g-mol

1.56E-01

8.03E-03

2.64E-01

5.02E-03

4.34E-01

4.65E-02

$3.87 \mathrm{E}-01$

Acid in heel, g-mol

acid to add, $\mathrm{g}-\mathrm{mol}$

Formic Acid Required, g

20.21

final acid, M 0.321

Copper Requirement

Heel + Feed - Benzene

Formic, $\mathrm{g}$

Copper Soln, $\mathrm{g}$

PHA, g

20.21

20.85

833.07

final Cu, ppm 475

833.07

Copper in $1.47 \%$ Sol'n, g

0.307

Copper in Heel, $\mathbf{g}$

0.089

Total Copper in PHA, $g$

0.396

\section{Summary}

Heel Solution, $\mathrm{g}$

1.47 wt\% Cu Solution, $\mathrm{g}$

90 wt\% Formic, $g$

Aq. Prod. Recycle, g

Water, $\mathrm{g}$

Amount

187.69

20.85

20.21

0.00

28.13
Heel mass, $\mathrm{g}$

234.3

Heel Volume, $\mathrm{ml} \quad 232.057$

Heel Acid, M

0.200

Heel Copper, ppm 1688.32 
Phenylboronic Acid Destruction Rate Constant Calculation for the Process Demonstration Experiments

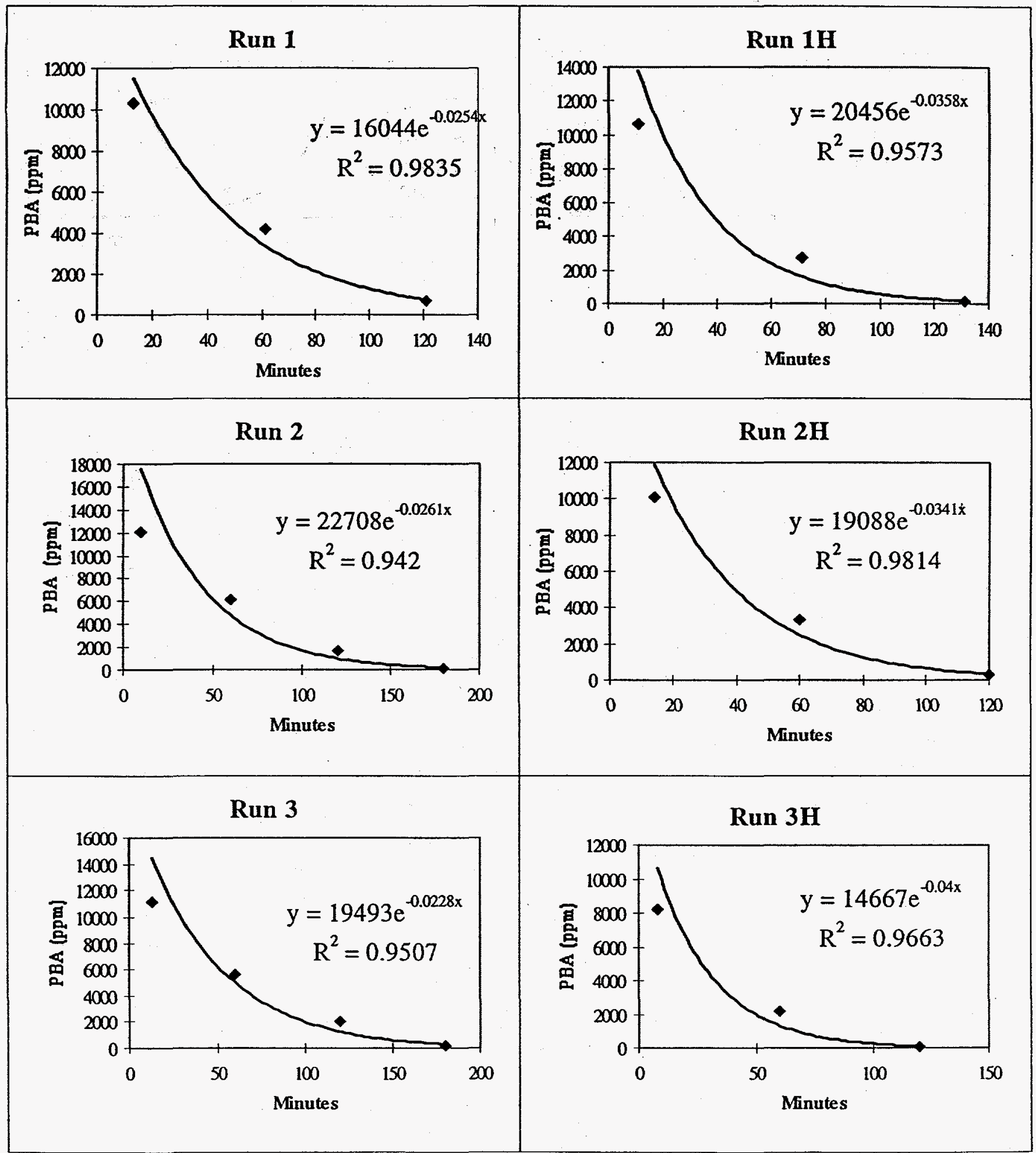


Appendix C - Calculations

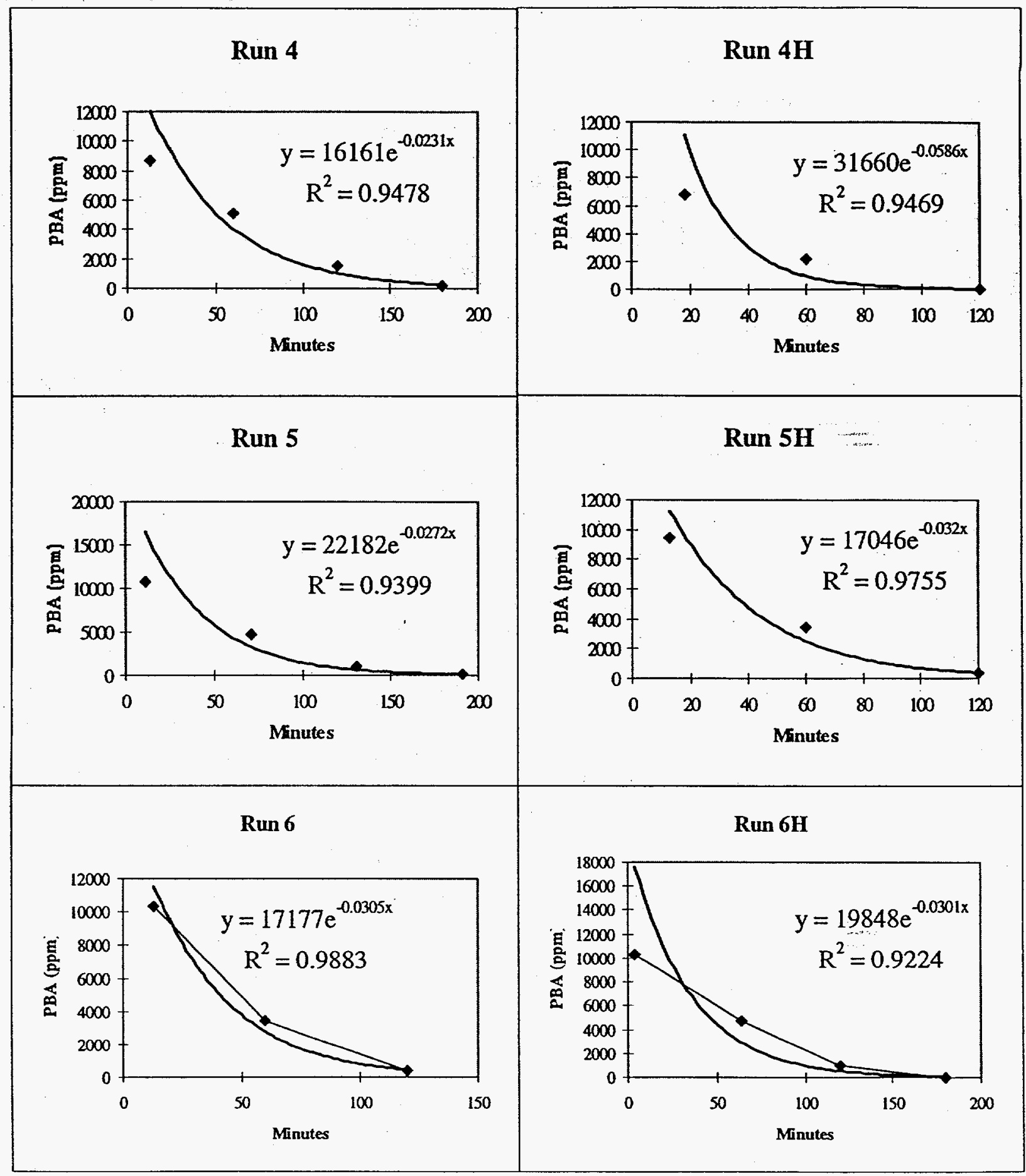


Appendix C - Calculations

Statistical Data

\begin{tabular}{|c|c|c|c|c|c|c|c|}
\hline \multicolumn{8}{|c|}{ Least Significant Difference Determinations } \\
\hline & \multirow{2}{*}{\multicolumn{3}{|c|}{ Number }} & \multirow{3}{*}{$\begin{array}{c}\text { Standard } \\
\text { Deviation of } \\
\text { Differences }\end{array}$} & \multirow{3}{*}{$\begin{array}{c}\text { Standard } \\
\text { Error of the } \\
\text { Differences }\end{array}$} & \multirow{3}{*}{$\begin{array}{c}\text { Least } \\
\text { Significant } \\
\text { Difference }\end{array}$} & \multirow[b]{3}{*}{$\begin{array}{l}\text { Significant } \\
\text { at } 5 \% \text { level }\end{array}$} \\
\hline \multirow{3}{*}{$\begin{array}{c}\text { Organic } \\
\text { Compound }\end{array}$} & & & & & & & \\
\hline & $\begin{array}{l}\text { Product } \\
\text { Stream }\end{array}$ & $\begin{array}{c}\text { of } \\
\text { Pairs }\end{array}$ & $\begin{array}{c}\text { Average of the } \\
\text { Differences }\end{array}$ & & & & \\
\hline & & & Ibs & Ibs & Ibs & \begin{tabular}{|l|} 
lbs \\
\end{tabular} & \\
\hline \multirow[t]{3}{*}{ Aniline } & Aqueous & 6 & -0.040 & 0.3145 & 0.1284 & 0.33 & No \\
\hline & Organic & 6 & -0.070 & 0.1101 & 0.0449 & 0.12 & No \\
\hline & Product & 6 & -2.218 & 2.1568 & 0.8805 & 2.26 & No \\
\hline \multirow[t]{3}{*}{ Biphenyl } & Aqueous & 6 & -0.002 & 0.0056 & 0.0023 & 0.01 & No \\
\hline & Organic & 6 & -20.408 & 62.0154 & 25.3177 & 65.08 & No \\
\hline & Product & 6 & 0.062 & 0.6261 & 0.2556 & 0.66 & No \\
\hline \multirow[t]{3}{*}{ Diphenylamine } & Aqueous & 6 & 0.002 & 0.0092 & 0.0037 & 0.01 & No \\
\hline & Organic & 6 & 2.170 & 2.5048 & 1.0226 & 2.63 & No \\
\hline & Product & 6 & 0.749 & 0.4902 & 0.2001 & 0.51 & Yes \\
\hline \multirow[t]{3}{*}{ Phenol } & Aqueous & 6 & -0.050 & 0.4374 & 0.1786 & 0.46 & $\mathrm{No}$ \\
\hline & Organic & 6 & -1.642 & 4.1981 & 1.7139 & 4.41 & No \\
\hline & Product & 6 & 2.743 & 2.6010 & 1.0619 & 2.73 & Yes \\
\hline \multirow[t]{3}{*}{ m-Terphenyl } & Aqueous & 6 & 0.000 & 0.0013 & 0.0005 & 0.00 & No \\
\hline & Organic & 6 & -0.027 & 0.1293 & 0.0528 & 0.14 & No \\
\hline & Product & 6 & -0.293 & 0.2492 & 0.1017 & 0.26 & Yes \\
\hline \multirow[t]{3}{*}{ o-Terphenyl } & Aqueous & 6 & -0.002 & 0.0100 & 0.0041 & 0.01 & $\mathrm{No}$ \\
\hline & Organic & 6 & -0.073 & 0.5757 & 0.2350 & 0.60 & No \\
\hline & Product & 6 & 0.124 & 0.4633 & 0.1891 & 0.49 & No \\
\hline \multirow[t]{3}{*}{ p-Terphenyl } & Aqueous & 6 & 0.000 & 0.0013 & 0.0005 & 0.00 & No \\
\hline & Organic & 6 & 0.018 & 0.0439 & 0.0179 & 0.05 & No \\
\hline & Product & 6 & -0.062 & 0.0799 & 0.0326 & 0.08 & No \\
\hline
\end{tabular}

If the average of the differences between these pairs of observations (No Heel - Large Heel) in absolute value is larger than the least significant difference, then the No Heel and Large Heel results declared to be statisticlly different. The level of confidence in such a determination is $95 \%$. 
Appendix C - Calculations

Organic/Product

Aniline / Aqueous

Large PHA Heel (pounds) By Small PHA Heel (pounds)

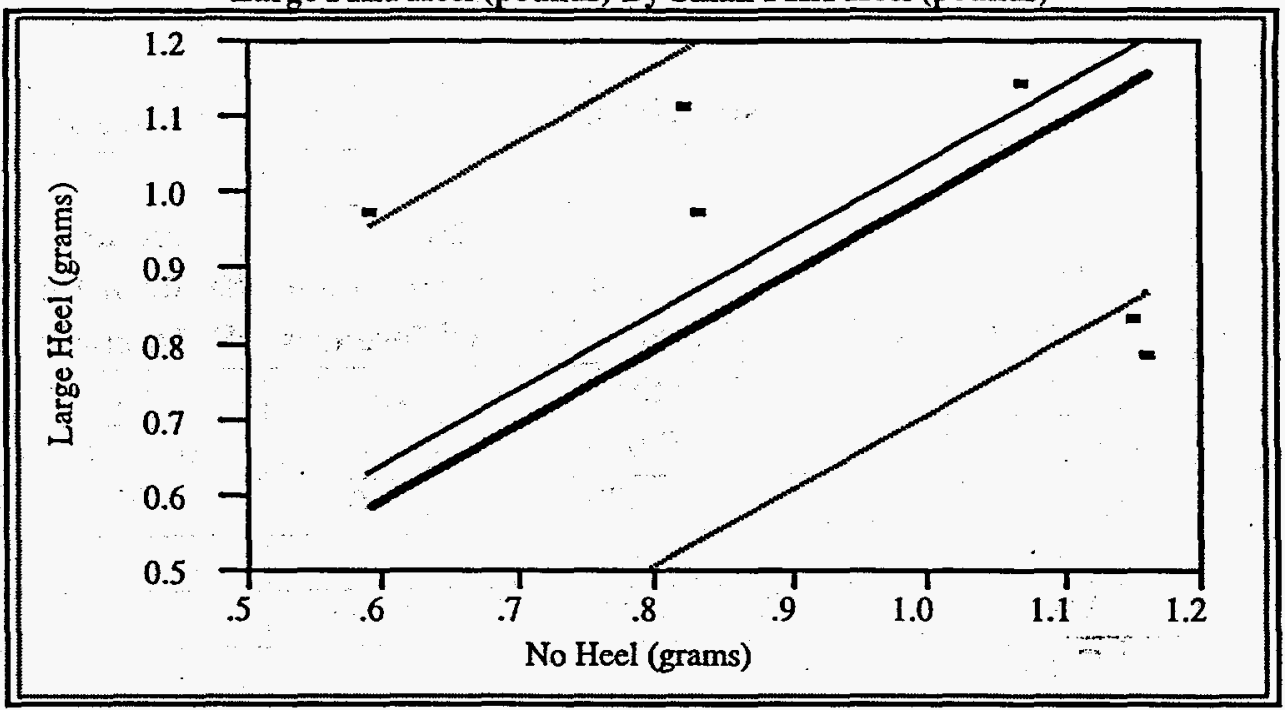

Paired t-Test

Small PHA Heel (pounds) - Large PHA Heel (pounds)

Mean Difference

$-0.04$

Prob $>|t|$

0.7679

Std Error

0.128374

Prob $>t$

0.6160

t-Ratio

$-0.31159$

Prob $<\mathrm{t}$

0.3840

DF

5

Organic/Product

Aniline / Organic

Large PHA Heel (pounds) By Small PHA Heel (pounds)

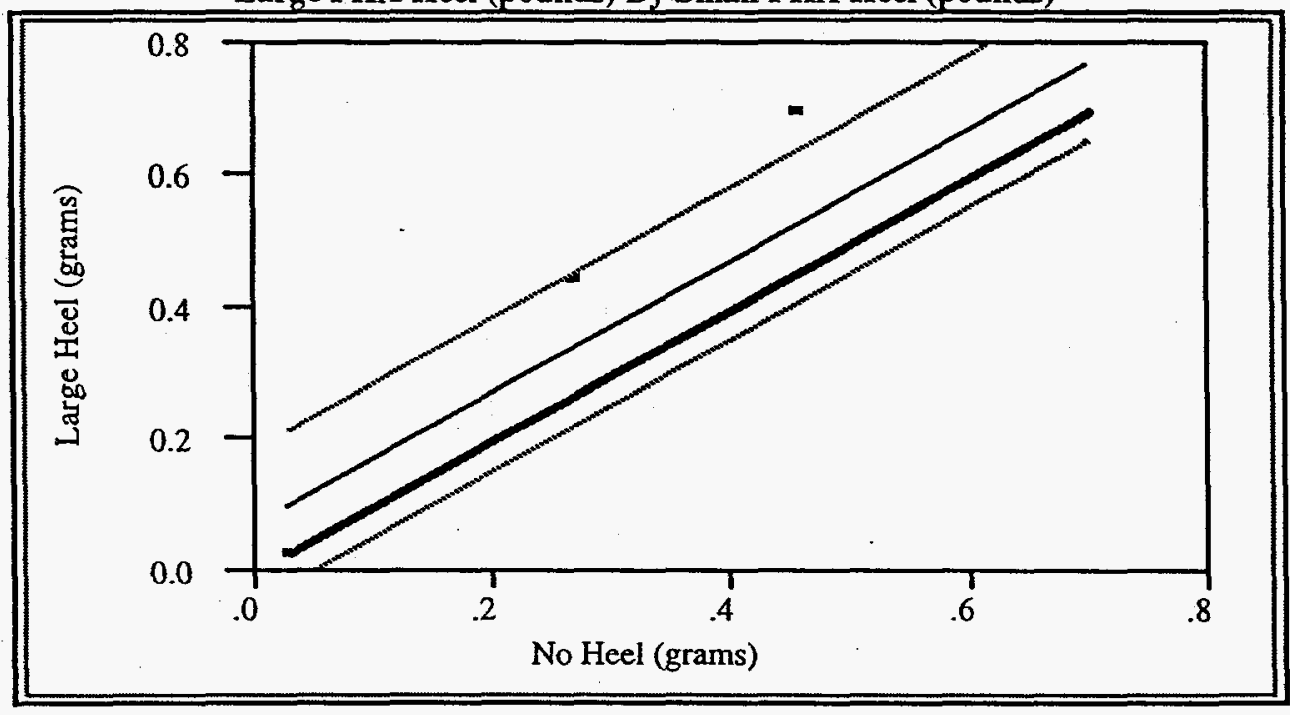

Paired t-Test

Small PHA Heel (pounds) - Large PHA Heel (pounds)

Mean Difference

$-0.07 \quad$ Prob $>1 \mathrm{t}$

0.1801

Std Error

0.044944

Prob $>$ it

0.9100

t-Ratio

$-1.55748$

Prob $<\mathrm{t}$

0.0900

DF 
Appendix C - Calculations

Organic/Product

Aniline / Product

Large PHA Heel (pounds) By Small PHA Heel (pounds)

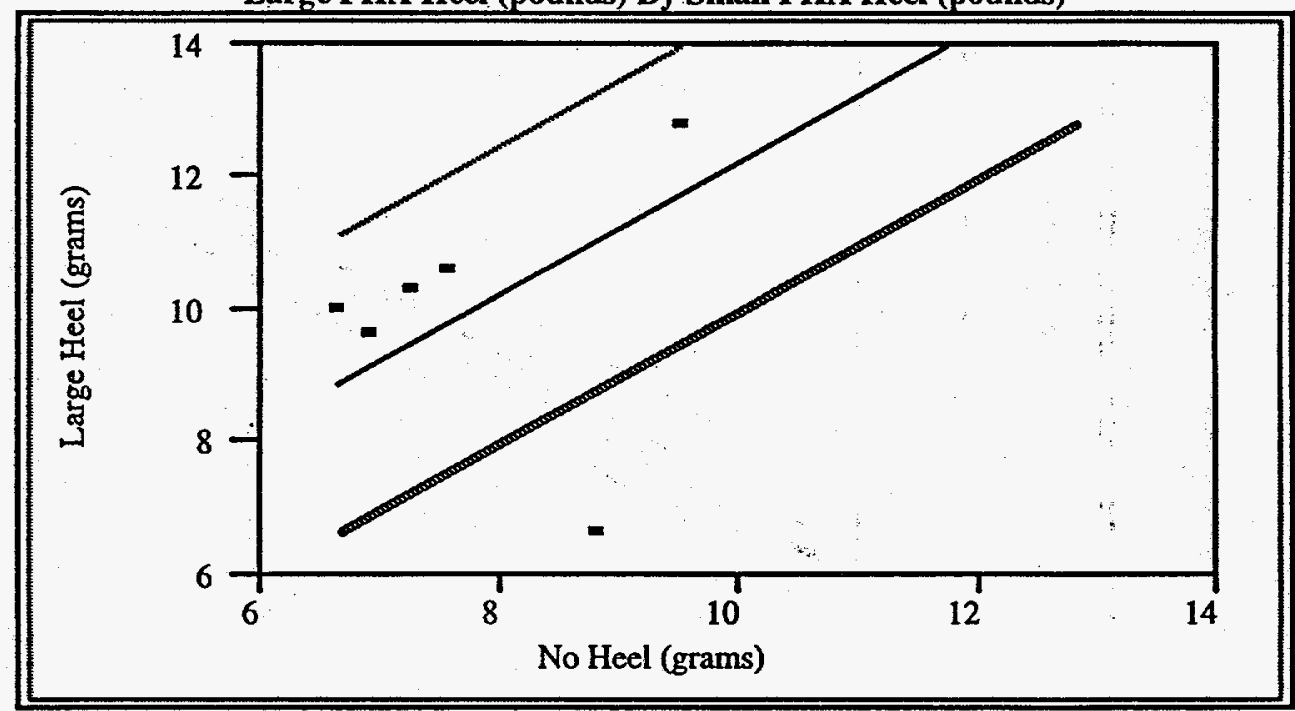

Paired t-Test

Small PHA Heel (pounds) - Large PHA Heel (pounds)

$\begin{array}{lrll}\text { Mean Difference } & -2.21833 & \text { Prob }>\text { tt } & 0.0532 \\ \text { Std Error } & 0.880501 & \text { Prob }>t & 0.9734 \\ \text { t-Ratio } & -2.5194 & \text { Prob }<t & 0.0266 \\ \text { DF } & 5 & & \end{array}$

Organic/Product

Biphenyl / Aqueous

Large PHA Heel (pounds) By. Small PHA Heel (pounds)

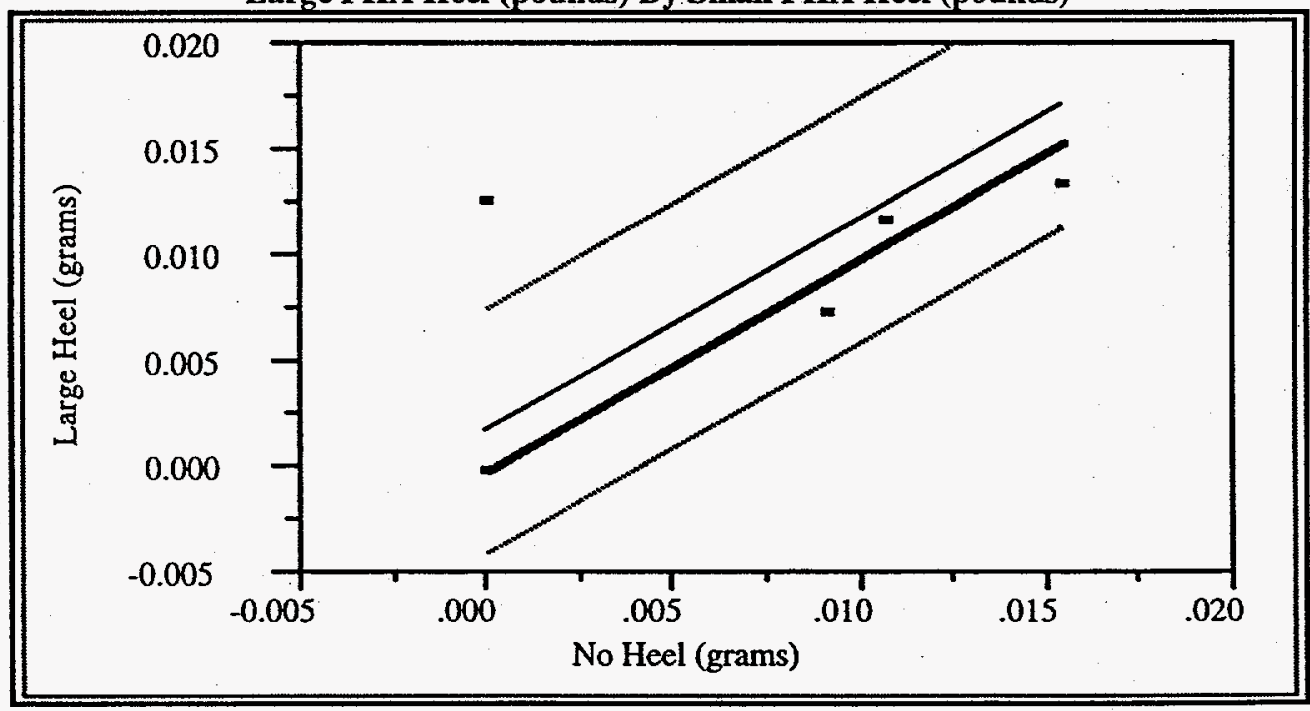

Paired t-Test

Small PHA Heel (pounds) - Large PHA Heel (pounds)

Mean Difference

$-0.00175 \quad$ Prob $>|t|$

0.4743

Std Error

0.002268

Prob $>t$

0.7629

t-Ratio

$-0.7733$

Prob $<t$

0.2371

DF

5 


\section{Appendix C - Calculations}

Organic/Product

Biphenyl / Organic

Large PHA Heel (pounds) By Small PHA Heel (pounds)

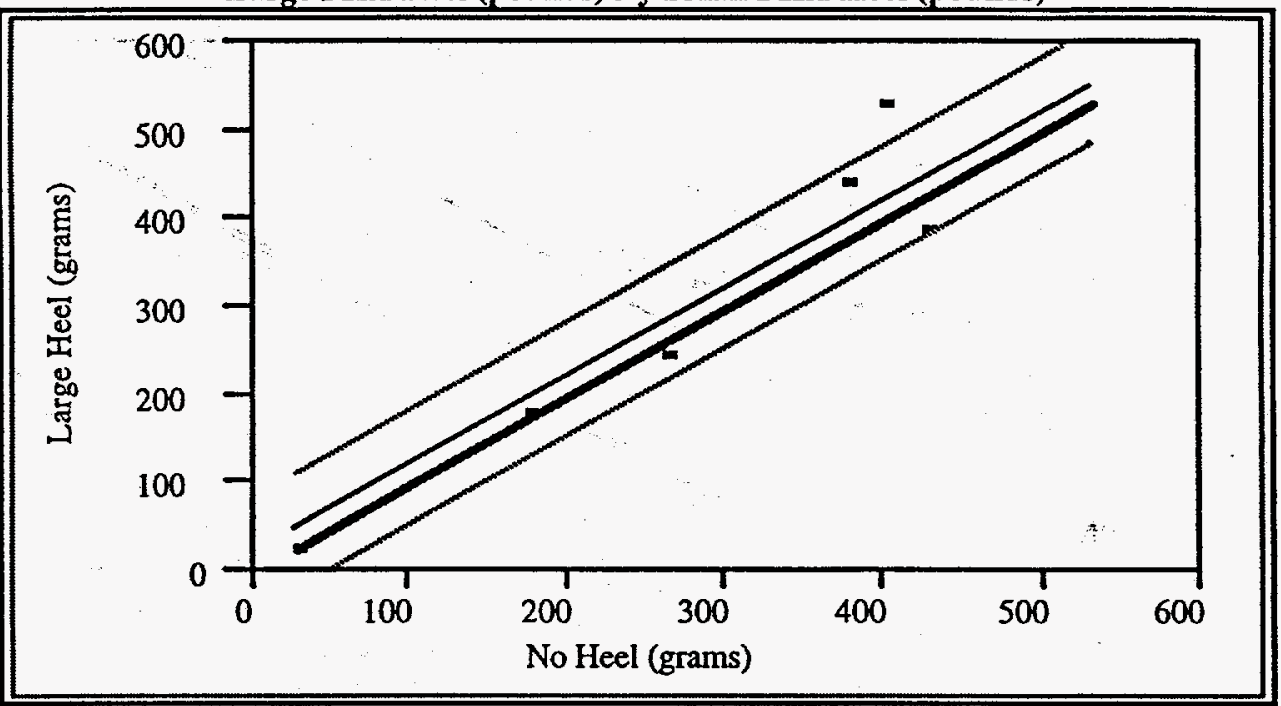

Paired t-Test

Small PHA Heel (pounds) - Large PHA Heel (pounds)

Mean Difference

Std Error

t-Ratio

DF

$$
\begin{array}{r}
-20.4083 \\
25.31769 \\
-0.80609 \\
5
\end{array}
$$

0.4568

0.7716

0.2284

Organic/Product

Biphenyl / Product)

Large PHA Heel (pounds) By Small PHA Heel (pounds)

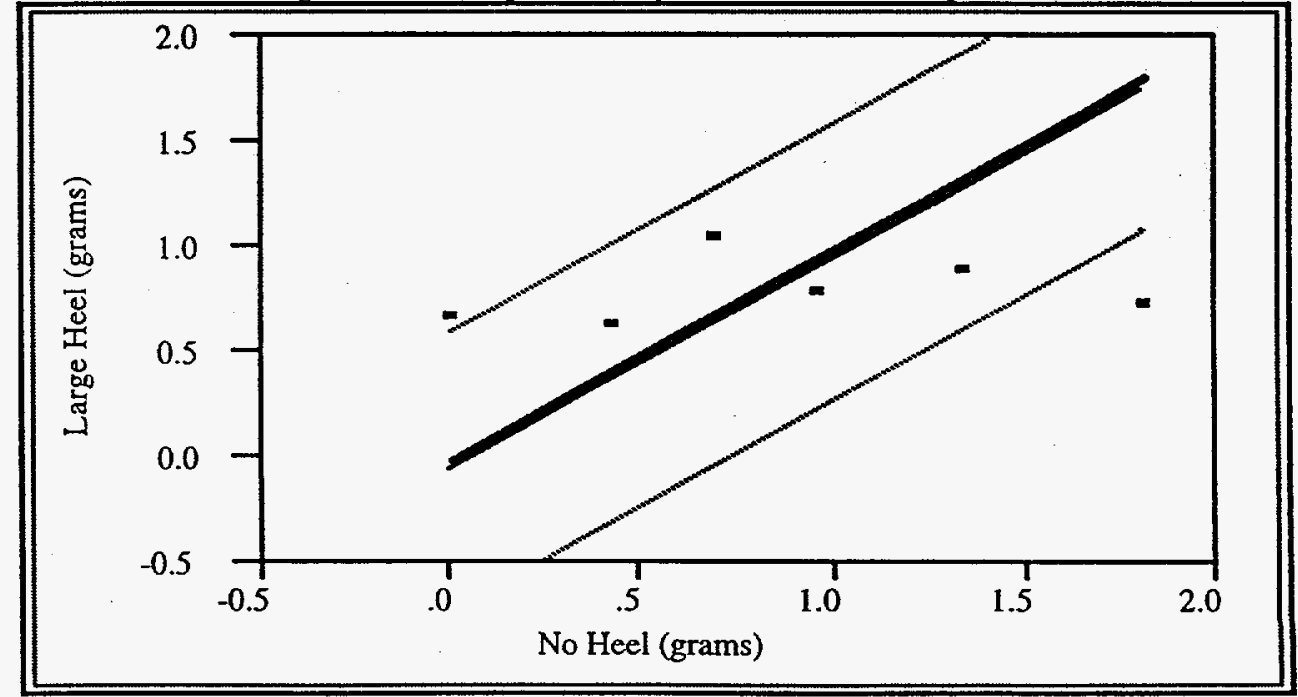

Paired t-Test

Small PHA Heel (pounds) - Large PHA Heel (pounds)

Mean Difference

0.062479

0.25562

Prob $>|t|$

0.8166

Std Error

0.244422

0.4083

t-Ratio

DF

5

Prob $<t$

0.5917 


\section{Appendix C - Calculations}

Organic/Product

Diphenylamine / Aqueous

Large PHA Heel (pounds) By Small PHA Heel (pounds)

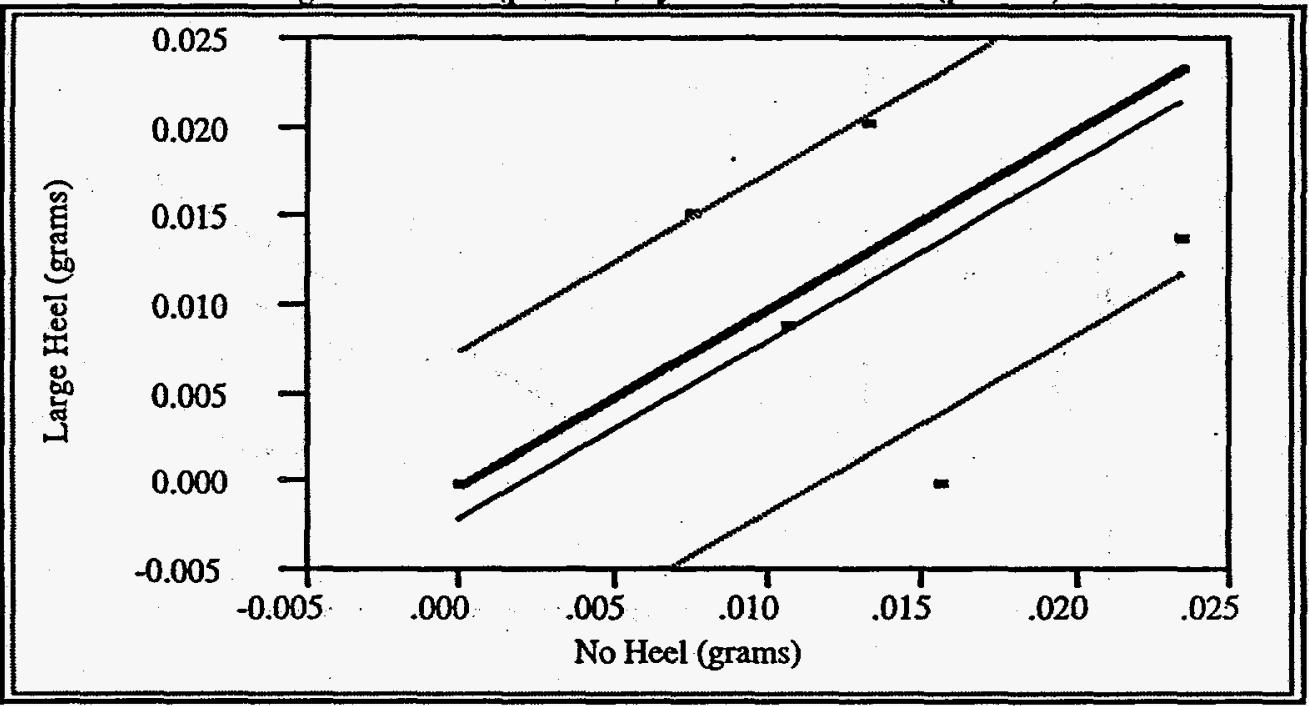

Paired t-Test

Small PHA Heel (pounds) - Large PHA Heel (pounds)

$\begin{array}{lrcr}\text { Mean Difference } & 0.002012 & \text { Prob }>\text { tt } & 0.6140 \\ \text { Std Error } & 0.003743 & \text { Prob }>t & 0.3070 \\ \text { t-Ratio } & 0.537388 & \text { Prob }<t & 0.6930 \\ \text { DF } & 5 & & \end{array}$

Organic/Product

Diphenylamine / Organic

Large PHA Heel (pounds) By Small PHA Heel (pounds)

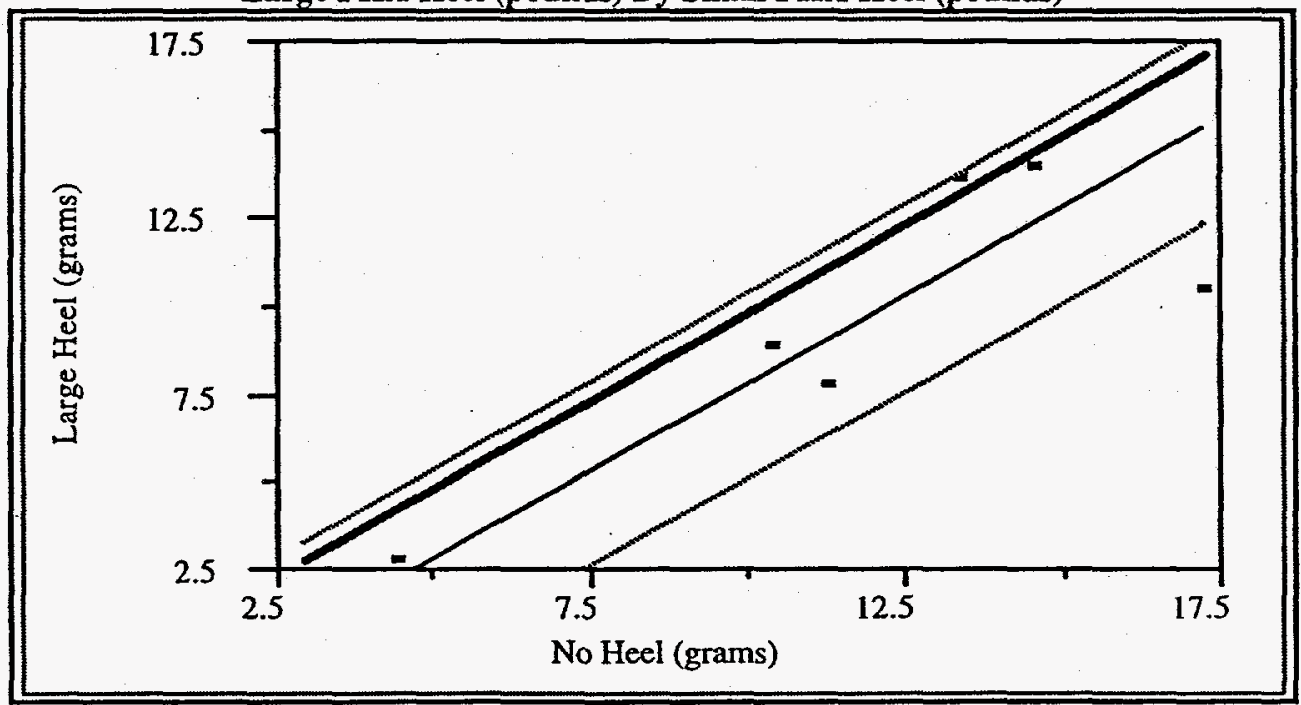

Paired t-Test

Small PHA Heel (pounds) - Large PHA Heel (pounds)

Mean Difference

2.170118

Prob $>|t|$

0.0873

Std Error

1.022566

Prob $>t$

0.0436

t-Ratio

2.122227

Prob $<t$

0.9564

DF 


\section{Appendix C - Calculations}

Organic/Product

Diphenylamine / Product

Large PHA Heel (pounds) By Small PHA Heel (pounds)

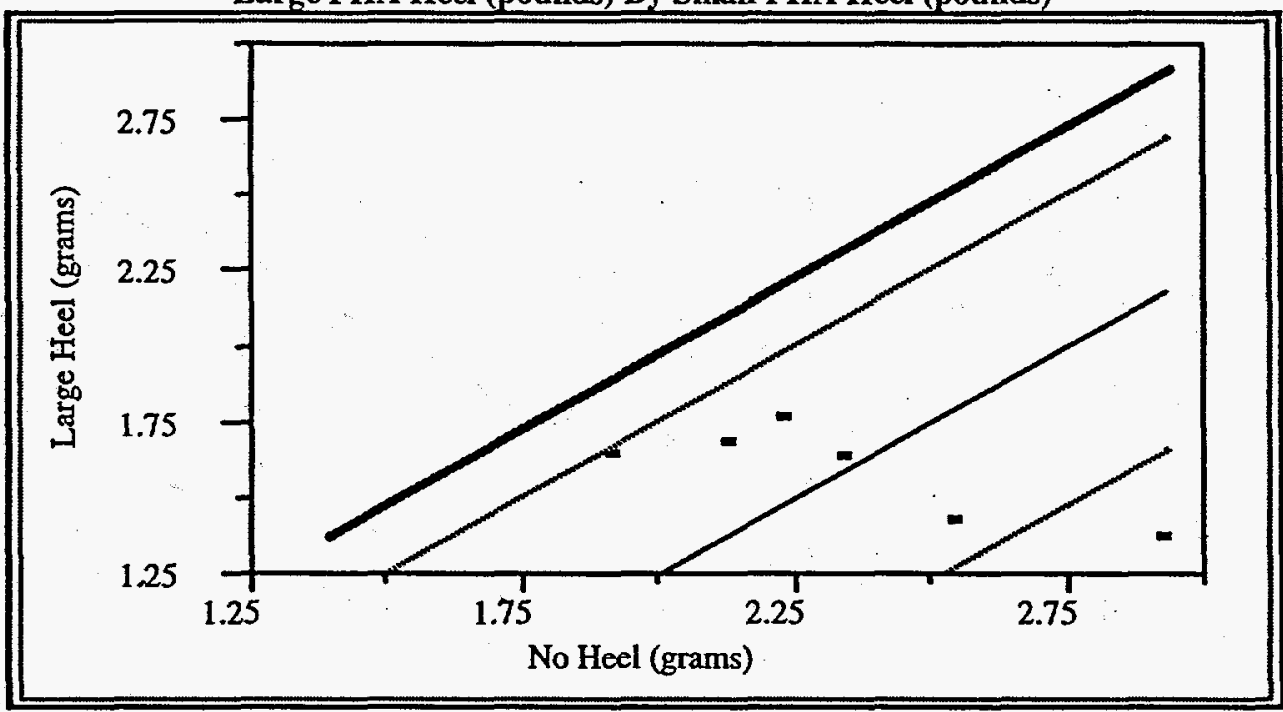

Paired t-Test

Small PHA Heel (pounds) - Large PHA Heel (pounds)

$\begin{array}{lrll}\text { Mean Difference } & 0.748568 & \text { Prob }>|t| & 0.0134 \\ \text { Std Error } & 0.200129 & \text { Prob }>\text { t } & 0.0067 \\ \text { t-Ratio } & 3.740429 & \text { Prob }<\text { t } & 0.9933 \\ \text { DF } & 5 & & \end{array}$

Organic/Product

Phenol / Aqueous

Large PHA Heel (pounds) By Small PHA Heel (pounds)

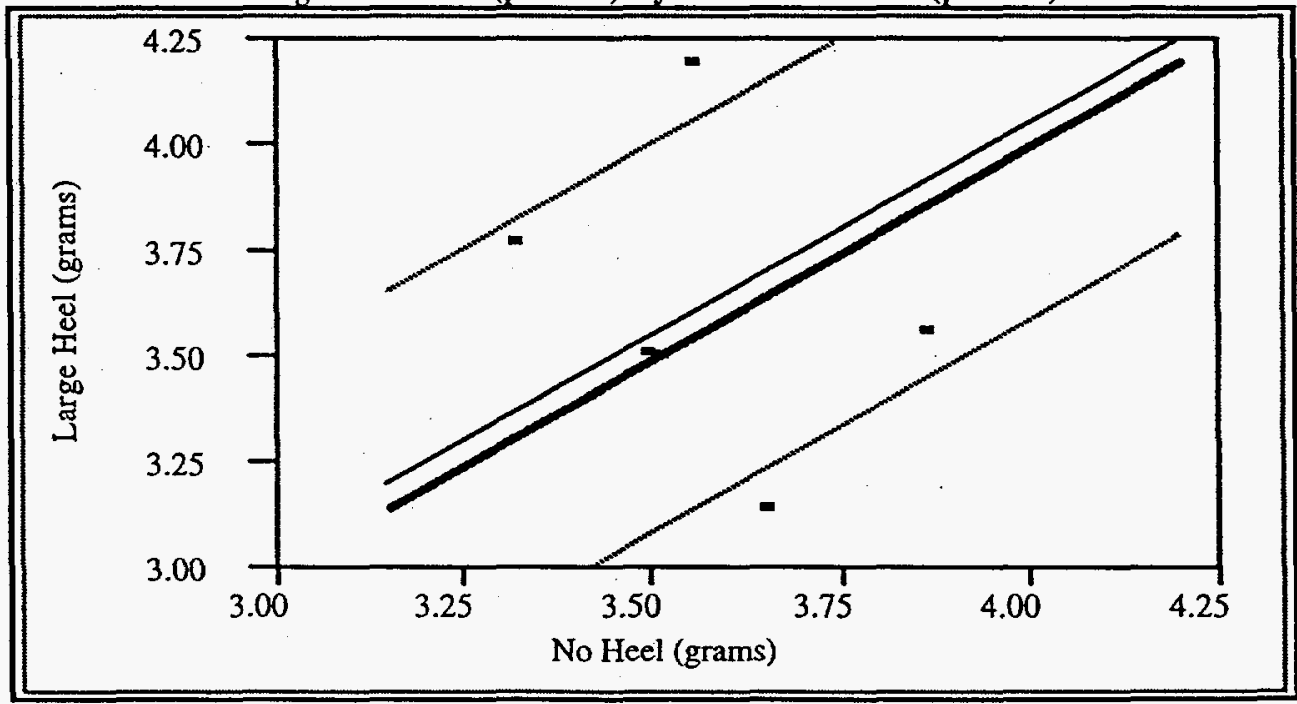

Paired t-Test

Small PHA Heel (pounds) - Large PHA Heel (pounds)

Mean Difference

$-0.05 \quad$ Prob $>|t|$

0.7907

Std Error

t-Ratio

0.178587

Prob $>t$

0.6046

DF

-0.27998
5

Prob $<t$

0.3954 


\section{Appendix C - Calculations}

Organic/Product

Phenol / Organic

Large PHA Heel (pounds) By Small PHA Heel (pounds)

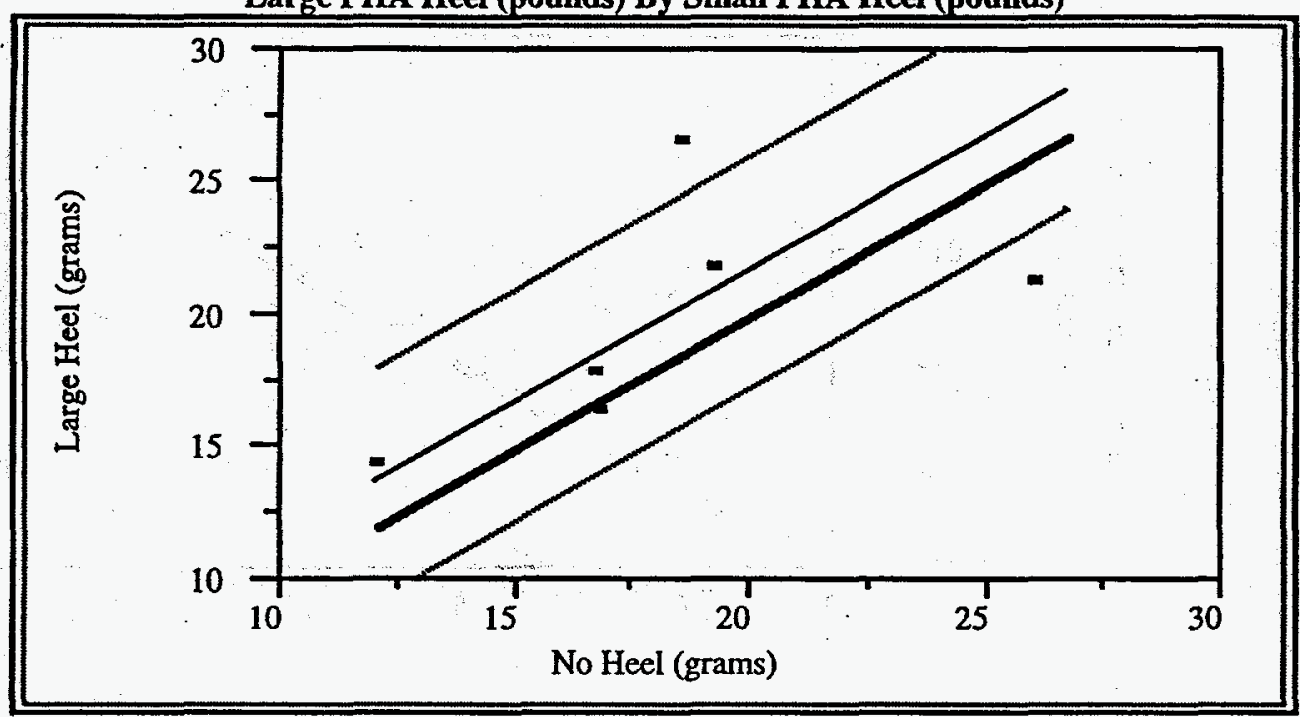

Paired t-Test

Small PHA Heel (pounds) - Large PHA Heel (pounds)

$\begin{array}{lrll}\text { Mean Difference } & -1.64167 & \text { Prob }>\text { tt } & 0.3821 \\ \text { Std Error } & 1.713879 & \text { Prob }>\text { t } & 0.8089 \\ \text { t-Ratio } & -0.95787 & \text { Prob }<\text { t } & 0.1911 \\ \text { DF } & 5 & & \end{array}$

Organic/Product Phenol / Product

Large PHA Heel (pounds) By Small PHA Heel (pounds)

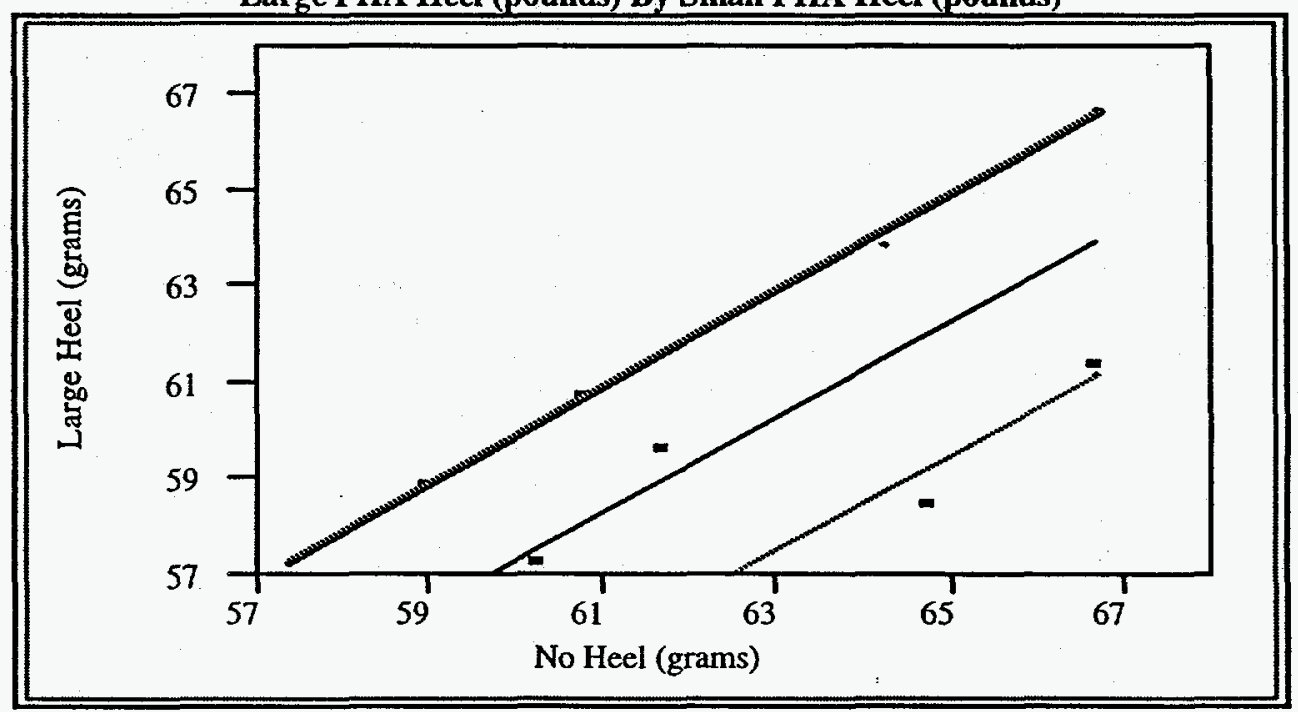

Paired t-Test

Small PHA Heel (pounds) - Large PHA Heel (pounds)

$\begin{array}{lrlr}\text { Mean Difference } & 2.743333 & \text { Prob }>\text { It } & 0.0492 \\ \text { Std Error } & 1.061865 & \text { Prob }>\text { t } & 0.0246 \\ \text { t-Ratio } & 2.583504 & \text { Prob }<\text { t } & 0.9754 \\ \text { DF } & 5 & & \end{array}$




\section{Appendix C - Calculations}

Organic/Product m-Terphenyl / Aqueous)

Large PHA Heel (pounds) By Small PHA Heel (pounds)

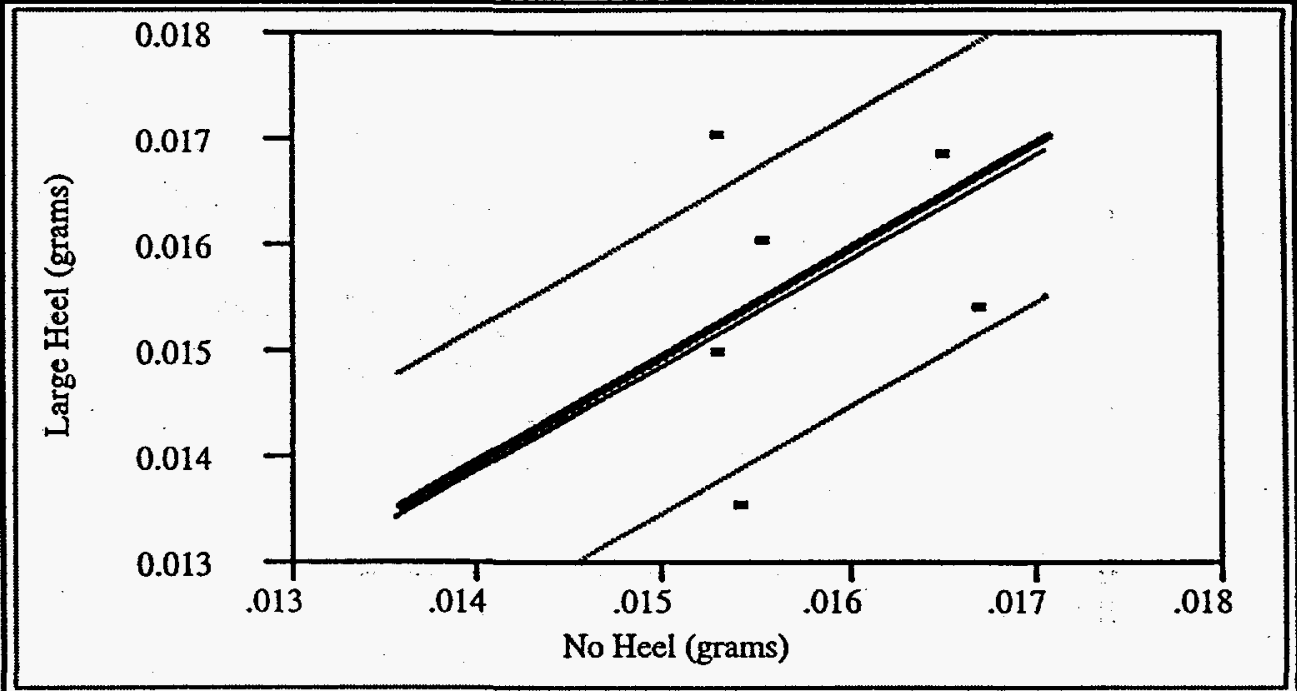

Paired t-Test

Small PHA Heel (pounds) - Large PHA Heel (pounds)

Mean Difference

Std Error

t-Ratio

$\mathrm{DF}$

$\begin{array}{lll}0.000143 & \text { Prob > tt } & 0.7999 \\ 0.000534 & \text { Prob > t } & 0.4000 \\ 0.267317 & \text { Prob < t } & 0.6000\end{array}$

5

Organic/Product m-Terphenyl / Organic)

Large PHA Heel (pounds) By Small PHA Heel (pounds)

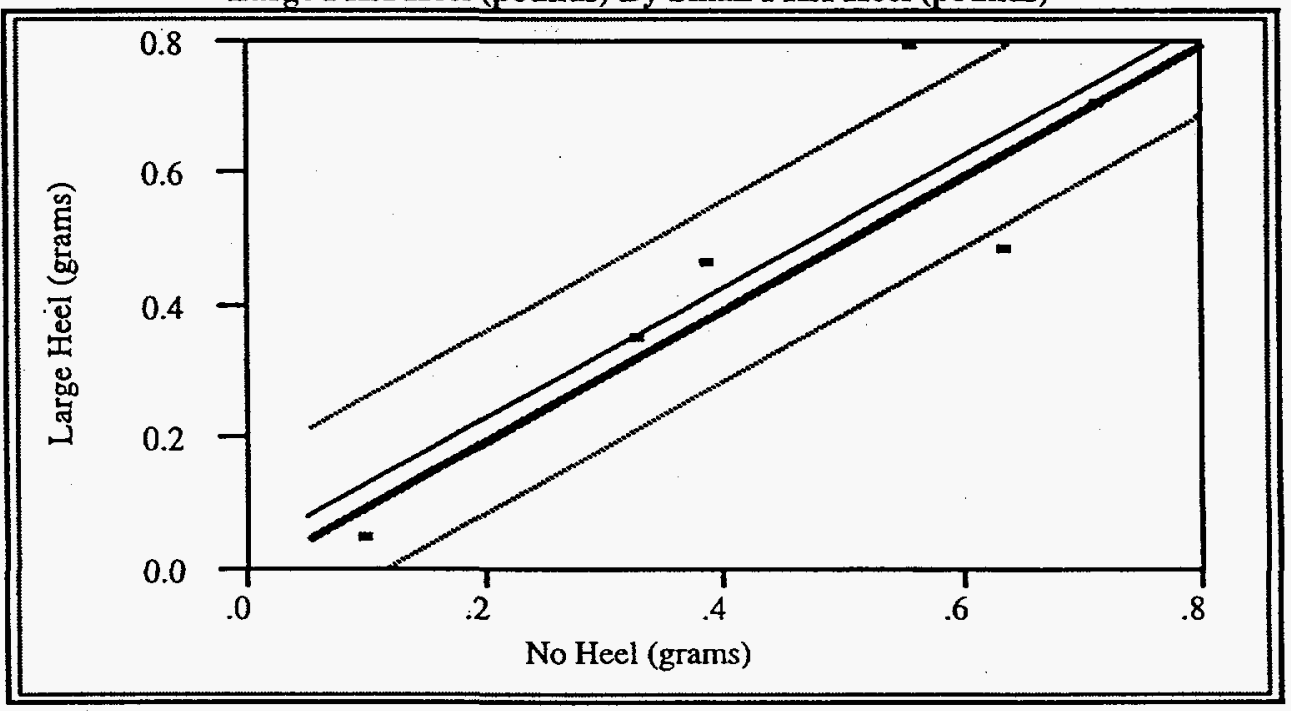

Paired t-Test

Small PHA Heel (pounds) - Large PHA Heel (pounds)

Mean Difference

$-0.02695 \quad$ Prob $>|t|$

0.6315

Std Error

0.052801

Prob $>t$

0.6843

t-Ratio

DF

$-0.51044$

Prob $<t$

0.3157 
Organic/Product

m-Terphenyl / Product

Large PHA Heel (pounds) By Small PHA Heel (pounds)

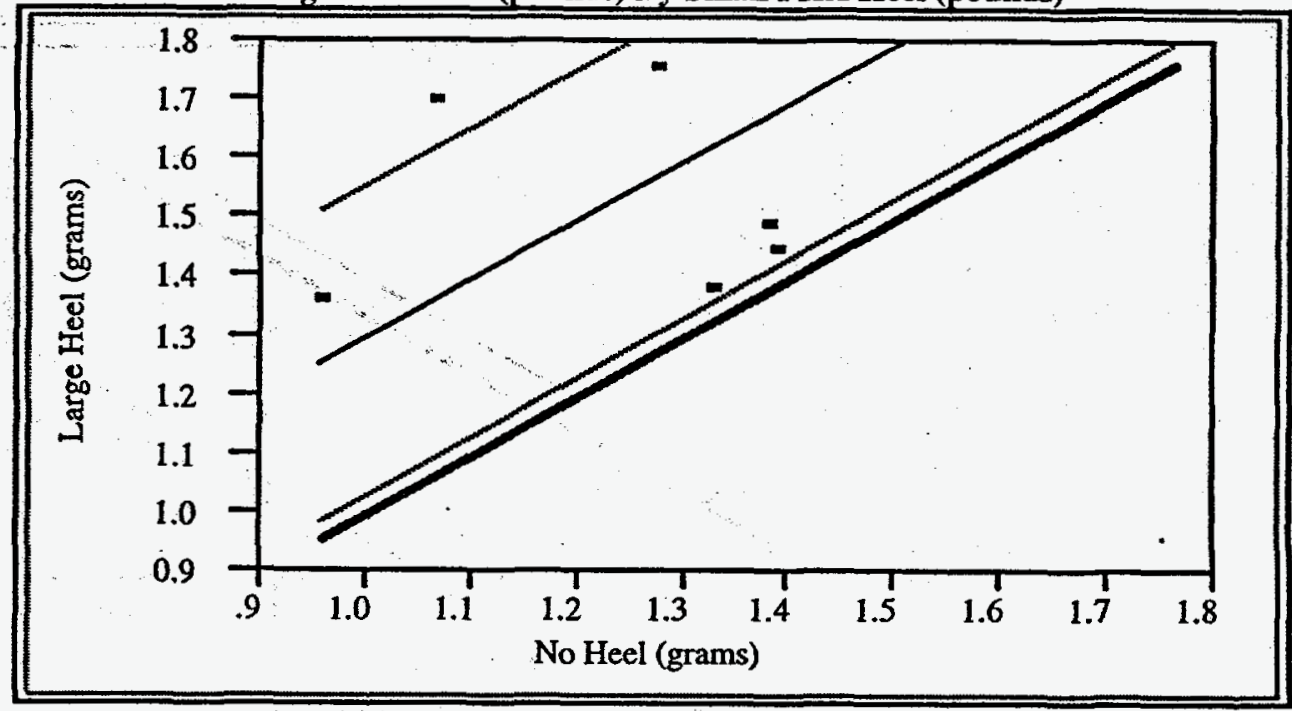

Paired t-Test

Small PHA Heel (pounds) - Large PHA Heel (pounds)

Mean Difference

Std Error

t-Ratio

DF
$-0.29269$

0.101742

$-2.87678$

5

$\begin{array}{ll}\text { Prob }>\text { t t } & 0.0347 \\ \text { Prob }>t & 0.9826 \\ \text { Prob }<t & 0.0174\end{array}$

Organic/Product

o-Terphenyl / Aqueous

Large PHA Heel (pounds) By Small PHA Heel (pounds)

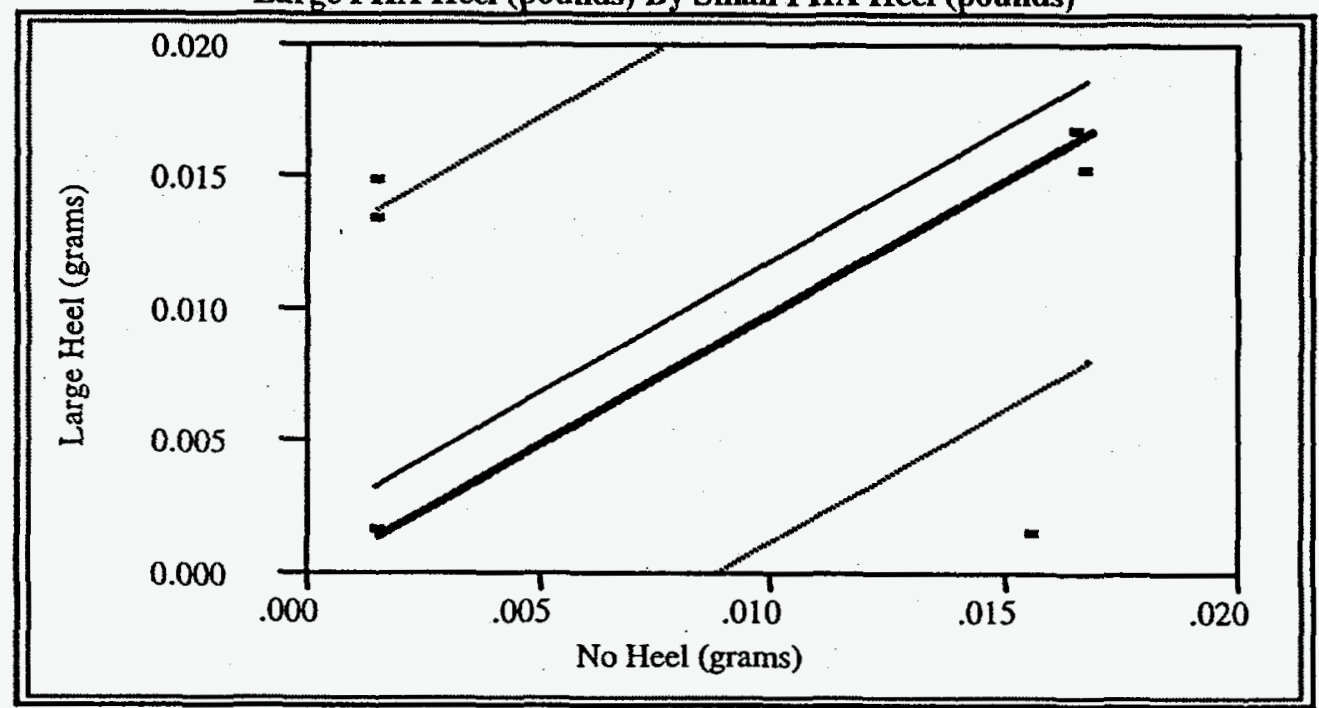

Paired t-Test

Small PHA Heel (pounds) - Large PHA Heel (pounds)

Mean Difference

Std Error

$-0.0018$

0.004097

$-0.43933$

t-Ratio

DF
Prob $>$ It

Prob $>t$

Prob $<$ t 
Appendix C - Calculations

Organic/Product

o-Terphenyl / Organic

Large PHA Heel (pounds) By Small PHA Heel (pounds)

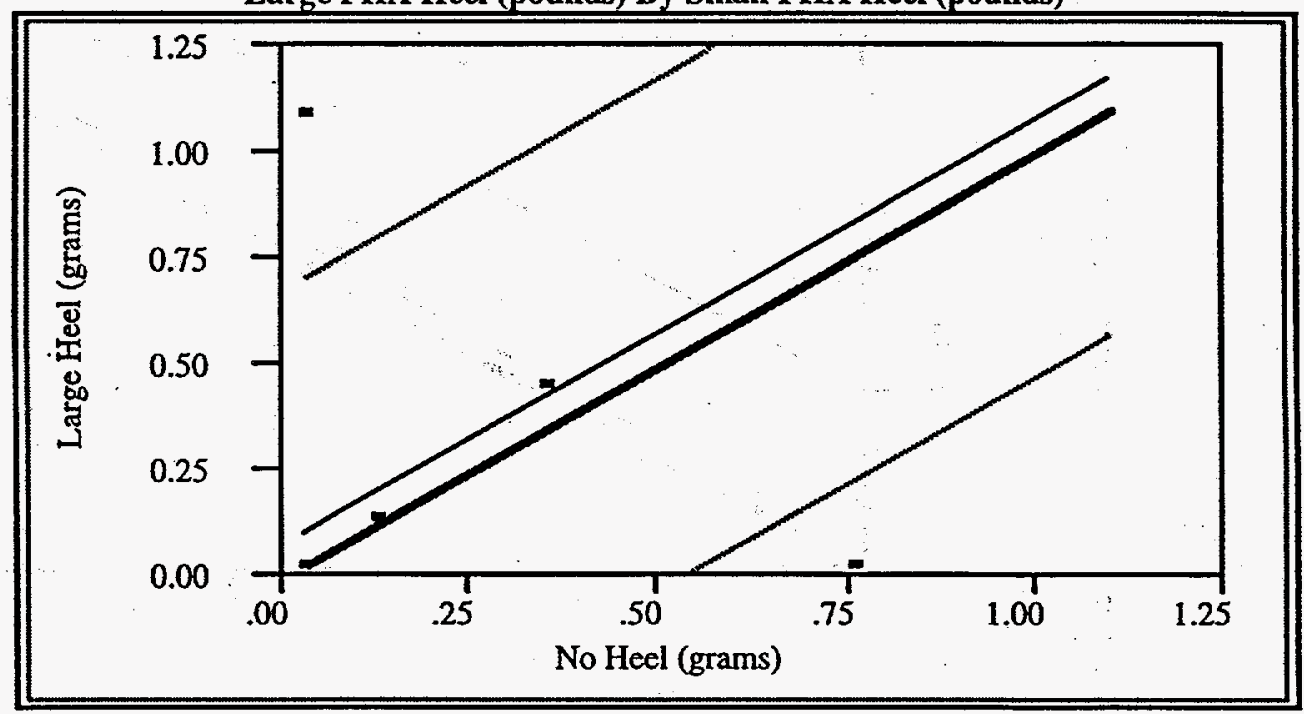

Paired t-Test

Small PHA Heel (pounds) - Large PHA Heel (pounds)

$\begin{array}{lrll}\text { Mean Difference } & -0.07317 & \text { Prob }>|t| & 0.7681 \\ \text { Std Error } & 0.23504 & \text { Prob }>t & 0.6159 \\ \text { t-Ratio } & -0.31129 & \text { Prob }<t & 0.3841 \\ \text { DF } & 5 & & \end{array}$

Organic/Product o-Terphenyl / Product)

Large PHA Heel (pounds) By Small PHA Heel (pounds)

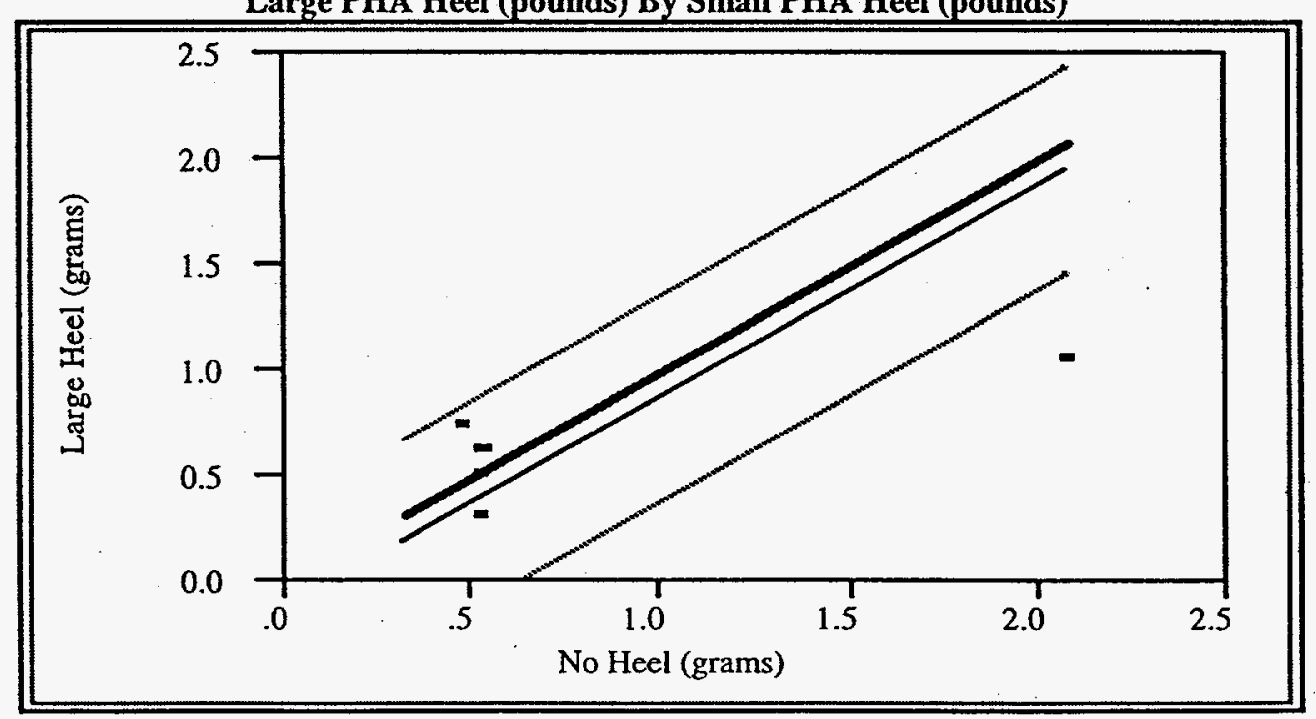

Paired t-Test

Small PHA Heel (pounds) - Large PHA Heel (pounds)

Mean Difference

Std Error

t-Ratio

DF
0.124274

0.189125

0.657097 5
Prob $>|t|$

Prob $>t$

Prob $<$ t

0.5402

0.2701

0.7299 


\section{Appendix C - Calculations}

Organic/Product

p-Terphenyl / Aqueous

Large PHA Heel (pounds) By Small PHA Heel (pounds)

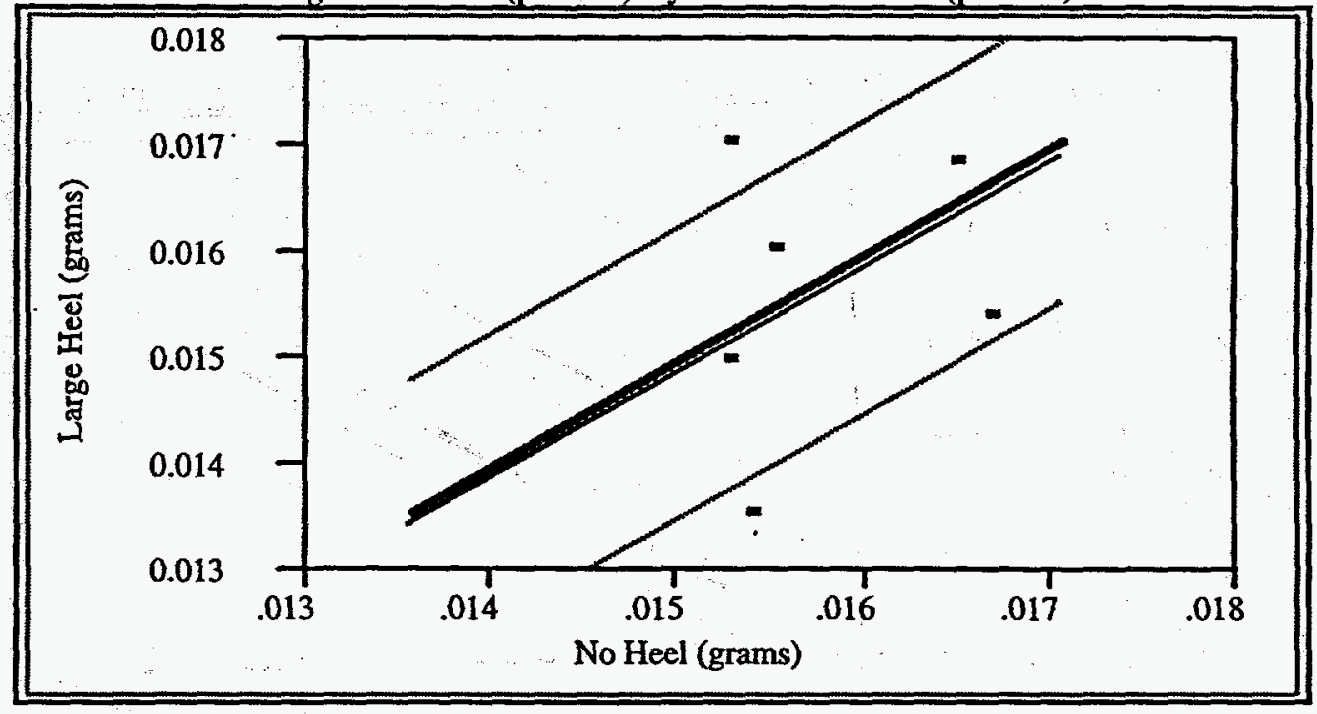

Paired t-Test

Small PHA Heel (pounds) - Large PHA Heel (pounds)

Mean Difference

$\begin{array}{lll}0.000143 & \text { Prob }>\text { tt } & 0.7999 \\ 0.000534 & \text { Prob }>t & 0.4000 \\ 0.267317 & \text { Prob }<t & 0.6000\end{array}$

t-Ratio

DF

Organic/Product

p-Terphenyl / Organic

Large PHA Heel (pounds) By Small PHA Heel (pounds)

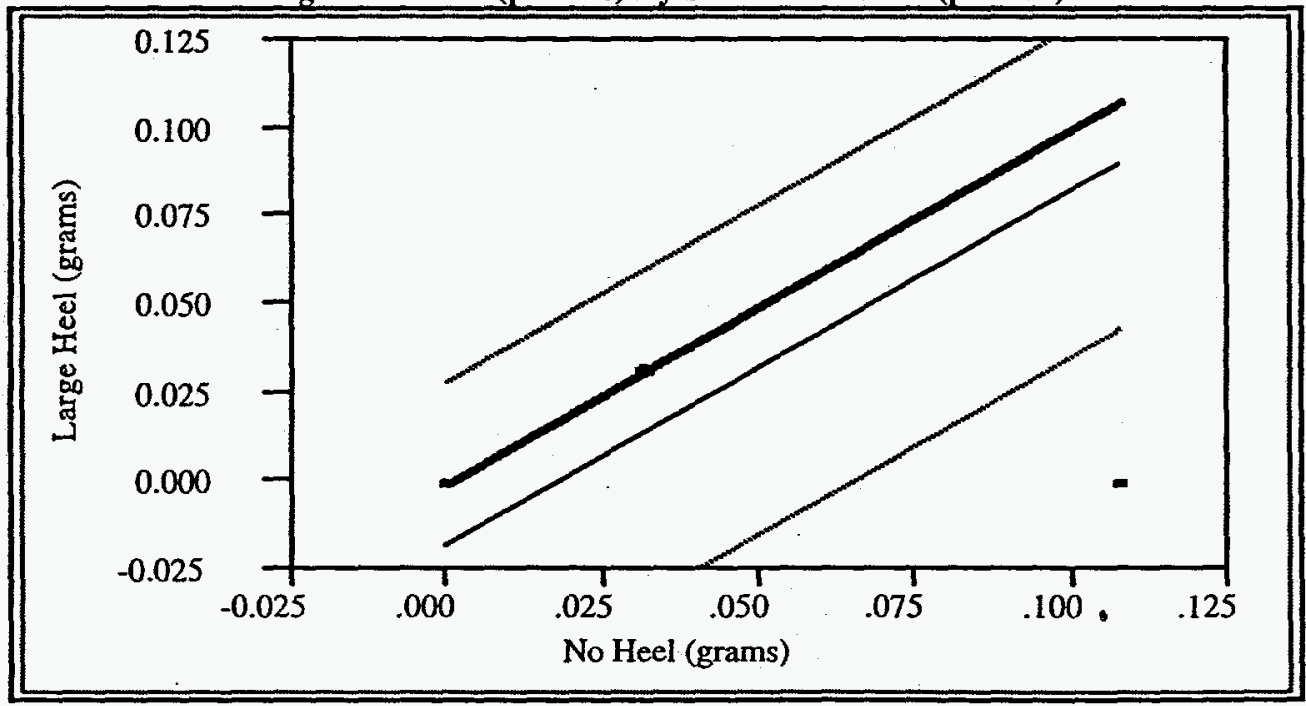

Paired t-Test

Small PHA Heel (pounds) - Large PHA Heel (pounds)

Mean Difference

0.018131

Prob $>|t|$

0.3582

Std Error

0.017923

Prob $>t$

t-Ratio

1.011597

Prob $<\mathrm{t}$

0.1791

DF

5




\section{Appendix C - Calculations}

Organic/Product p-Terphenyl / Product

Large PHA Heel (pounds) By Small PHA Heel (pounds)

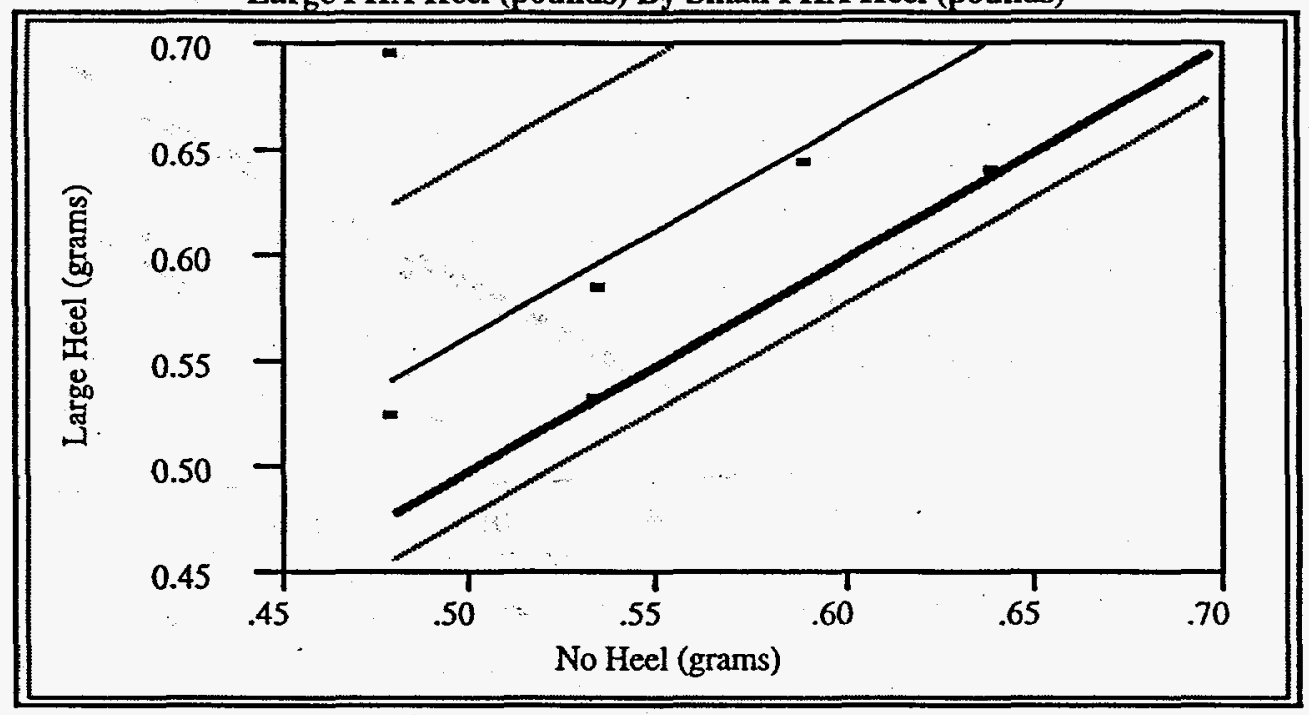

Paired t-Test

Small PHA Heel (pounds) - Large PHA Heel (pounds)

Mean Difference

Std Error

t-Ratio

DF
$-0.06209 \quad$ Prob $>|t|$

$0.032615 \quad$ Prob $>t$

$-1.90377 \quad$ Prob $<t$

5
0.1153

0.9423

0.0577 